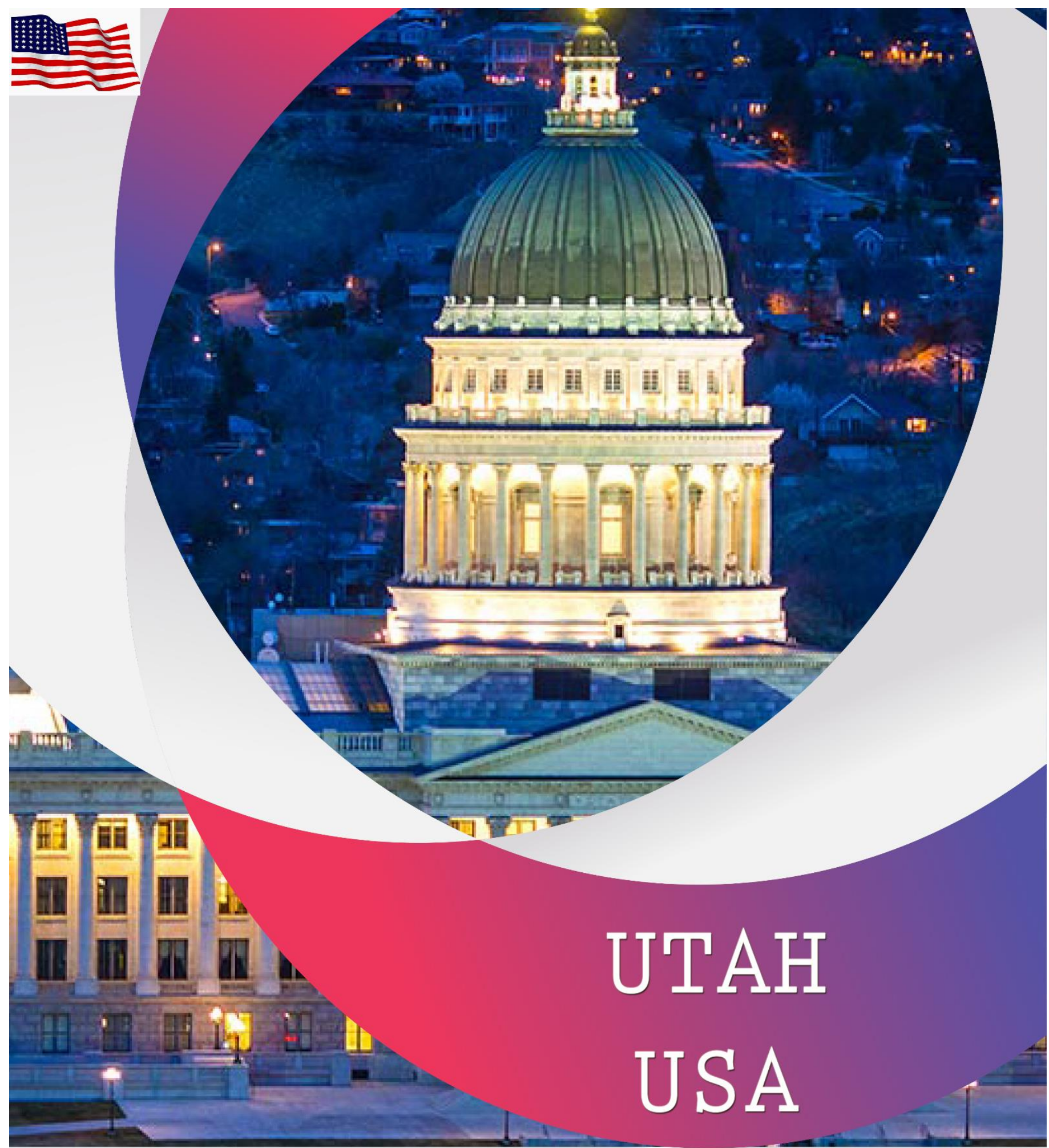

\title{
INNOVATIVE DEVELOPMENT DISCOURSE MODERN SCIENCE AND EDUCATION
}

\section{$\sqrt{ }$

$$
\text { 2021-05-30 }
$$

Semantic Scholar OPEN ACCESS gi Google

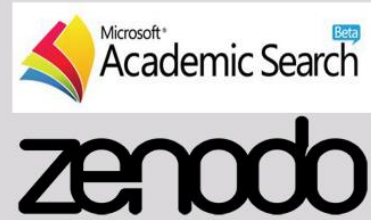

$\checkmark$ Crossref do 


\title{
INTERNATIONAL SCIENTIFIC AND CURRENT
}

\author{
RESEARCH CONFERENCES
}

“INNOVATIVE DEVELOPMENT DISCOURSE MODERN SCIENCE AND EDUCATION"

CONFERENCE DATE

30-05-2021

Doi - https://doi.org/10.37547/iscrc-intconfo8

\section{INTERNATIONAL SCIENTIFIC AND CURRENT RESEARCH CONFERENCES}

\author{
Utah, USA \\ $\checkmark$ Crossref doi gु Google \\ Editor In Chief
}

Prof. Dr. Ipsita Banerjee

Department of Chemistry, Fordham University NY 10458, USA 


\title{
SUPPORTING EDITORS
}

\author{
Peter Curtis, \\ Chapel Hill, USA \\ Malek Jedidi, \\ Assistant Professor Higher Institute Of Technological St udies B.P.88, 3099 Sfax, Tunisia \\ Ramel D Tomaquin, \\ Prof. Vi Surigao Del Sur State University Rosario, Tandag City . Philippines \\ Dr. Devarajan Ramasamy, \\ Senior Lecturer Faculty Of Mechanical Engineering, Universiti Malaysia Pahang, \\ 26600,Pekan,Pahang, Malaysia \\ Hu Jiye, \\ PhD, Master's degree of law, B.E. (Machinery Department) \\ Professor of Law and Finance Center for Law and Economics, China University of Political Science \\ and Law China University of Political Sciences and Law 25 Xitucheng Road, Beijing, 100088, China
}

\section{Elena A. Makarova,}

Ph.D.in Psychology, Bachelor degree (Education)

Professor of Psychology Department at Taganrog Institute of Management and Economics,Taganrog, Russian Federation.

Prof. PinnamaneniBhanu Prasad,

Ph.D.

Rajalakshmi Engineering College, India and Matrix Vision GmbH, Germany

Dr. Ahmed nabihZakiRashed,

Ph.D

Dept. of Electronic\& ECE., University of Menoufia, Egypt

Dr. Ahmed nabihzakiRashed,

Ph.D

Dept. of Electronic\& ECE., University of Menoufia, Egypt 
1. Abrorjon Pulatov

2. Wurster, $\mathbf{M}$.

3. Ravshan Chorshanbiev, Fayzilla Begimqulov

4. Dilshod Aroev, Mavjuda Gafurova, Avazbek Sobirov

5. Holden M

6. Akram Sultanov

7. Khakima Davlatova, Ozodbek Nematov

8. Edwards BF

9. Lutfillo Maxamadaliev

10. Mehrinoz Mamurova, Munira Matsapayeva

11. Kendall P.M.

12. Gayratjon Abdurahmonov

13. Ali Kaljanov

14. Rose grant, M.W

15. Behruz Sayfullaev

16. Gulrukh

17. Jarvis, D.I

18. Bakhtiyor Mirzarahimov

19. Sadoqat Raimova
FACTORS INFLUENCING THE POLITICIZATION OF RELIGION IN $\quad \mathbf{1 - 5}$ MODERN TIMES

SANITATION INSTRUCTION PREPARE AND GUIDANCE ATTITUDE OF DIETITIANS: A MENTAL MODEL APPROACH

ANALYSIS OF ROOT HARVESTING MACHINE SELECTION $10-13$ DEVICES

ABOUT THE ROOTS OF A POLYNOMIAL WITH A WHOLE COEFFICIENT

ENVIRONMENTAL REVOLUTION VARIATION AND EMERGENCY RISK CONTRACTION IN PAKISTAN: WHERE ARE WE STANDING?

THE ROLE OF EDUCATIONAL EVENTS IN THE COOPERATION OF FAMILY, SCHOOL, COMMUNITY IN PROTECTING DISADVANTAGED STUDENTS FROM ALIEN IDEOLOGIES TRADITIONAL JEWELERIES AND DECORATIONS

26-28

A TRANSPARENT NATURAL EXEMPLARY OF RIVER

29-31 MEANDERING

THE PROCESS OF LOCALIZATION OF GOVERNMENT OFFICES IN THE NATIONAL POLICY OF THE SOVIET POWER IN THE 20S OF THE XX CENTURY

PROBLEMS OF TRANSLATION OF CUSTOMS TERMS IN ENGLISH AND UZBEK LANGUAGES

A CURRENT ADDITION TO PREREQUISITE OILS: CHEMISTRY, BIOACTIVITY AND PROSPECTS FOR AUSTRALIAN CULTIVATION

IDEOLOGICAL UNITY AND SPIRITUAL REVIVAL

47-50

THE SHORT STUDY OF MULTIPLE HOMONYMS IN

51-53 KARAKALPAK LANGUAGE

CONNECTING EXECUTIVE, CLIMATE AND MORPHOGENETIC 54-56 AND ANATOMICAL INGREDIENT OF A SWARD FOR AFFECT TILLER FREQUENCY GESTURE IN BAHIA GRASS FROM THE HISTORY OF CULTURAL RELATIONS BETWEEN UZBEKISTAN AND INDIA

$57-60$

THE EFFECT OF MIMICS AND VISION IN TEACHER-STUDENT COMMUNICATION

61-64

DISCOVERING APPROACH TO DEVELOP AUSTRALIA'S MEAL PRESERVATION POSITION

$65-68$

69-75 OF ITS IMPLEMENTATION

PHILOSOPHICAL IDEAS IN THE WORKS OF ABU ABDULLAH RUDAKI 
20. Kanawha K. Chaugai

21. Dilnavoz Tursunova

22. Oygul Ashurova

23. Gayratjon Abdurahmonov

24. Castaner, L

25. A'zamjon Dusmatov, Sherzod Tokhtaev, Shaxboz Isaev, Olimjon Sarimsaqov

26. Abubakir Shermatov, Mirjavokhir Mirov, Shakhzod Tojiyev

27. Mumtozbegim Kholmatova

28. Wellhöfer, M

29. Xabibulla Muratov

30. Sanjar Toshtemirov, Obidjon Khamroyev

31. Oynisa Umirzokova

32. Abbosjon Soyibnazarov

33. Vincent A. Franco

34. F.R. Rehman

35. Sarvinoz Azizkhonova

36. Lutfillo Maxamadaliev

37. Rikhsi Kamilovna Solikhodzhaeva, Jamilakhon Erkinovna Kamilova

38. Z.I. Sattorova

39. M.T. Yuldasheva
LOCAL AREA ASPECT ON THE ON-FIELD DIVERSIFICATION OF SIX MAJOR BRAN AND HUMIDITY CHANGE IN BHUTAN

THE CONCEPT OF SOCIAL ACTIVITY AND ITS IMPORTANCE IN SOCIAL DEVELOPMENT

THE IMPORTANCE OF AESTHETICITY OF ECOLOGICAL CONSCIOUSNESS AND CULTURE IN THE ACTIVITIES OF PRESCHOOL EDUCATIONAL PROFESSIONALS

THE DIALECTICS OF RELIGIOUS AND WORLDLY TOLERANCE PRINCIPLES

SELF-BUILD FLUORINATED STRUCTURANTS FOR SURFACE TREATMENT

CHANGES OF COTTON'S NATURAL PROPERTIES IN THE PROCESS OF STORAGE AND STORAGE

STABILITY ANALYSIS AND STUDY OF ETHYLENE GLYCOL MONOMER AND DIMER COMPLEX

UZBEKISTAN BANK SYSTEM

108-111

112-114

FERMENTATIVE AND FIELD APPLY ADJUST: UTILIZING CURRENT PROOF TO MODEL ESTIMATES

THE IMPORTANCE OF EDUCATION IN THE FORMATION OF YOUTH CIVIL ACTIVITY IN THE HIGHER EDUCATION SYSTEM

THEORETICAL JUSTIFICATION OF THE PARAMETERS OF THE COMBINED MACHINE

THE ROLE OF MASS MEDIA IN TEACHING FOREIGN LANGUAGES

THE IMPORTANCE AND ROLE OF ONLINE COURSES IN THE TRAINING SYSTEM

SINGLE-GRINDING DIFFRACTOMETER FOR ACTINIC RADIATION EXTREMELY SHORT PULSES

PILLAR CAPTION FROM GWALIOR; A STUDY

136-139

ABOUT AZIMKHOJA ESHAN DEVON'S MANUSCRIPT AND HIS

$140-143$ STUDY

THE CONCEPT OF NATIONAL STATE THINKING

144-148 SIGNIFICANCE AND CONTENT

THE LEVEL OF FEELING OF HAPPINESS AMONG NURSES

$149-152$ STUDYING AT THE DEPARTMENT "NURSE WITH HIGHER EDUCATION" AT THE CENTER FOR ADVANCED TRAINING OF MEDICAL WORKERS

DĪWĀN LUGHĀT AL-TURK - UNIQUE ENCYCLOPEDIC

153-156 HERITAGE

FEATURES OF CLINICAL PARAMETERS IN PATIENTS WITH ISCHEMIC STROKE WHO UNDERWENT COVID-19 
40. Francisco A.S.

41. Fotima Ergashevna G'oziyeva, Matluba Berdali qizi Eshmuradova
MATHEMATICAL REPRODUCTION OF ENERGETIC, YTTERBIUM-DOPED AMPLIFIER TUNABILITY

PSYCHOLOGICAL FACTORS IN THE ADAPTATION OF 168-173 


\title{
FACTORS INFLUENCING THE POLITICIZATION OF RELIGION IN MODERN TIMES Abrorjon Pulatov, Independent researcher National University of Uzbekistan named after Mirzo Ulugbek Tashkent, Uzbekistan
}

\begin{abstract}
Religion has always been an important factor affecting all aspects of society. The level of religiosity in the world is not decreasing, on the contrary, it is rising at the contemporary stage. After the two-polarization period, "we have to celebrate the return of traditionalism. " It primarily belongs to Islam.
\end{abstract}

KEYWORDS: Modern reality, younger generation, Arab occupation, Crusades, religious massacres, etc.

\section{INTRODUCTION}

The rapid development of modern socio-political relations, the rapid development of communications and information technologies have given rise to ideological influences, improved methods and tools, and spiritual threats have become a global problem. This actuality is also reflected in the fact that the minds and hearts of the peoples of different regions of the world are being transformed into a test site, in other words, an ideological landfill. Modern reality is manifested in the growing number of new ways and means of struggle for the soul and mind, especially in the above-mentioned attempts to use the religious factor. Particularly alarming are the activities of fanatical Islamists and religious extremist movements, who are trying to disguise religion and undermine our religious values in the face of threats to the spirituality of our children. Such forces are trying to use every form of evil to reach the minds and hearts of young people. Under the banner of religion, acts of looting and robbery, terrorism and aggression, and to the detriment of society, contribute to the formation of interethnic and interreligious hatred, nationalism and religious separatism among the younger generation. Therefore, to bring the young generation an in-depth analytical overview of the positive changes that have taken place in our lives against religious extremism and destructive attempts at fanaticism in the 21st century, enhancing their social activism and the slogan “opinion against opinion, ideology against ideology, enlightenment against vandalism” is more important than ever. 
The events of the last 30 years show that "the politicization of religion does not occur in a traditional, archaic society where the majority of the population is actively religious, but rather in a society that has reached a high level of modernization and secularization. "

In the later stages of human society development, religion's influence on politics became even more apparent. All of this was clearly reflected in religious and political realities such as religious wars (Arab occupation, Crusades, religious massacres, etc.).

\section{THE MAIN FINDINGS AND RESULTS}

The active involvement of religion in political life also demonstrates the processes taking place in the world today. For example, in the basis of the religious outlook various organizations are founded, and they are actively involved in public and political life. The authority of some traditional Western European elites is based on tradition and religious values. Some religious leaders in Southeastern Asia are publicly influencing public officials (for example, Buddhist monks in Myanmar and Ceylon). All of this proves that the link between the existing spheres of social life of people has existed since ancient times and will continue to be so. The difference is that in certain historical periods this relationship may be strengthened or vice versa and there may be conflicts between them.

In recent times, there has been an increase in the popularity of high-ranking clerics on religious issues, their active involvement in political life, and the expansion of missionary activity. With the increase in the number of supporters and expansion of influence, the status of individual religious-territorial institutions is also expanding.

Legalization of secular authorities or secular support of religious authorities is a sensitive issue. The secular government with weak pillars needs the support of the clergy and religion in forming a new state. Consequently, there are cases of conversion to Islam in many Asian and African countries. In the Middle Ages, some Christian monarchs were regarded as high-ranking bishops, and were declared as "divine persons" or "representatives."

Experience of politicization of various religions (Islam, Catholicism, Protestantism, Hinduism, etc.) shows that politicization has always coincided with the emergence of alternative dual-networked social institutions. First of all, they fulfill many important social functions of the state, and secondly, they serve as the centers of advocacy and political activity. At the best of times, these alternative social institutions (educational institutions, hospitals, fundraisers, etc.) are becoming the starting point for seizing political power. 
In the last third of the twentieth century, critical process in the political life of some countries and in international politics have intensified due to the strengthening of the "Islamic factor" and the activation of Islamic groups with global religious and political programs. One of the most serious attacks against the international community is the intensification of politicization of the religious factor in all regions of Islam and the active use of terrorist attacks to achieve political goals.

Most researchers have identified this issue of the emergence of political and religious groups in all regions where Islam is spreading, and groups that work in politics is "happening as a system of religious ideas, relationships and institutions within Islam," but it mentions serious changes that doesn't always appear. This approach aims at identifying and analyzing the internal doctrinal sources of the emergence and development of political Islam. Today, there is a whole network of Islamic groups operating in different ways and with different programs.

The role of religion in society is increasingly determined not by the interests of religious organizations, but by the interests of the ruling elites, who artificially support the interest of religion in society, taking into account the centuries-old experience of religious organizations that have influenced people's minds and morals. In western civilization, religiosity is becoming more rational, more docile, and more manageable. Western standards are also penetrating the Muslim East.

At the intersection of politics and religion, we can witness the emergence of specific forms of international tension exaggerated by the media, Islamophobia, xenophobia, and antiSemitism. As a result, regional problems are becoming global.

We can see the rise of Islamic movements and religious and political parties in the Arab world at this time. Especially since 2010, the African Arab countries have given a new geopolitical picture. At first sight the protests were carried out against the former ruling regimes in Tunisia, Syria, Egypt, Libya and Yemen, the struggle in these countries was actually between religious extremists and secular rulers of the country. Tunisia and Egypt have apparently gone back to secular domination at the cost of large casualties, but Iraq, Syria, Libya and Yemen have been plunged into a civil war that has now become a religious factor that no one can predict when it will end.

The Government of the Republic of Uzbekistan has pursued a policy of strengthening religious tolerance as a basis for ensuring security and stability since the early days of independence, guaranteeing the free functioning of the country along with Islam and other 
religious confessions. All citizens, regardless of their nationality, race or religion, are guaranteed equal rights through our constitution and laws. This constitutional rule is also reflected in Article 5 of the new edition of the law which was adopted on May 1, 1998: "Law on Freedom of Conscience and Religious Organizations". The law establishes relations between state and religious organizations, taking into account historical, cultural, and social factors. After all, as President of Uzbekistan Sh.Mirziyoyev noted, "We believe that the most important task is to convey the true humanitarian nature of Islam to the world community. We cherish our sacred religion as an expression of our ancient values. We strongly condemn those who place our sacred religion in the line of violence and bloodshed, and we will never compromise. Islam calls for good and peace, and the preservation of true human qualities." Security, interethnic accord and religious tolerance, pursuing a well-thought-out, mutually beneficial foreign policy has been identified and reaffirmed the relevance of the issue as the fifth priority in the "Strategy of Actions for the Further Development of the Republic of Uzbekistan in 20172021".

Consequently, one of the most important ideological, ideological and even politically significant tasks of building a democratic state and civil society today is the severe and consistent struggle against the politicization of religion, including Islam in Uzbekistan.

There are all conditions for mutual respect between religious organizations of different faiths in our country. In its turn, in the provision of social and political stability in the republic, above all, religious tolerance and interethnic harmony are fully provided and legally guaranteed. This requires a particular approach in a multi-ethnic, multi-confessional country. It is worth noting that Uzbekistan has a rich experience in interethnic relations and religious tolerance. In our country, great attention is paid to the preservation of the national language, culture and traditions in the national self-consciousness. The principle of strengthening religious tolerance and uniting around one idea is being observed to ensure the unity of all nations and ethnic groups living in our country. As the President of the Republic of Uzbekistan Shavkat Mirziyoev noted: "It is known that in our ancient and generous land, for many centuries, representatives of different nationalities, cultures, religions have lived peacefully. " Consequently, goodness, generosity of heart and true tolerance, which is the eternal value of our people, are the basis of our mentality.

\section{CONCLUSION}

In general, while Central Asia's growing role in the global geopolitical arena, protecting our 
country, which occupies a main place in the region in terms of population and territory, from the stereotype of religious fanatics, preserving the conditions for citizens to exercise their faith, religious tolerance and interethnic harmony, further strengthening and developing the centuries-old traditions and customs of our people still remains as an important task for us.

\section{REFERENCES:}

1. Tibi B. Is Islam a Political Religion? The possibility of inter-religious pluralism in conditions of civilizational conflict // Inviolable reserve. 2002. - No. 6 (26).

2. Ravshanov, F. R., \& Azimov, H. Y. (2021). Danger and Security: History and Present. International Journal of Multicultural and Multireligious Understanding, 8(4), 280-285.

3. Muhammadsidikov M.M. State and Religious Relations in Arab Countries. Monograph. Qaqnus Media Publishing, 2019. - p. 27.

4. Ravshanovich, R. F., Tuigunovich, R. F., \& Yakubovich, A. H. (2020). Amir Temur and Turan States. Bulletin Social-Economic and Humanitarian Research, (5 (7)).

5. 3.Mitrofanova A.V. The politicization of the "Orthodox world". - M., 2004. - p. 42.

6. 4.Interethnic friendship and harmony is an important factor in the peace and wellbeing of our people. Speech of the President of the Republic of Uzbekistan Shavkat Mirziyoev at the meeting dedicated to the 25th anniversary of the Republican International Cultural Center. http://www.uza.uz/oz/politics/millatlararo-d-stlik-va-amzhi-atlik-khal-imiz-tinchligi-va-f-24-01-2017 7. Azimov, H. Y. (2021). Emergence Of New Threats To Turkey's National Security During The Syrian Crisis:“Euphrates Shield” Movement. The American Journal of Political Science Law and Criminology, 3(01), 42-48. 


\title{
SANITATION INSTRUCTION PREPARE AND GUIDANCE ATTITUDE OF DIETITIANS: A MENTAL MODEL APPROACH
}

\author{
Wurster, $\mathbf{M}$. \\ Department Of Agriculture, Mekong University, Vietnam
}

\section{ABSTRACT}

Health experts assume a significant part in guidance general society about food handling chances. In any case, the manners in which this significant gathering of teachers stays forward-thinking on these points are not distinct. In this examination, a public example of dietitians utilized in direct instructing of patients ( $n=327$ ) were enlisted to finish a web-conveyed study intended to foster a model of variables that advance data preparing and educating by and by about food handling identified with new vegetables. The subsequent mental model shows that dietitians instruct new vegetable security utilizing deliberate data preparing to mentally see new data, however this is additionally connected with a hole in the dietitian's instruction on sanitation. The juxtaposition of a data handling model with a social model gives significant new bits of knowledge about how dietitians look for, procure and make an interpretation of/move significant data to push patients toward a more significant standard of food handling. The examination additionally advises food handling instructors as they define instructing methodologies that are more compelling than different methodologies at advancing conduct change.

KEYWORDS: foodborne sickness; dietitians; mental models; data preparing conduct

\section{INTRODUCTION:}

In Europe and the United States (US), the public positions trust in wellbeing experts, trailed by food handling specialists and college researchers, as significant when assessing wellsprings of sanitation data. Trust in wellbeing experts is especially significant among shoppers who are at 
expanded danger of shrewd diseases because of invulnerable concealment, clinical treatment, life stage, or drug use. A progression of subjective examinations with exceptionally vulnerable patient gatherings in the US questioned where patients needed to discover sanitation data that identified with them and their condition. Members in these examinations needed trustworthy data from confided in sources, and medical services suppliers were the data source they liked. Each gathering named their doctor as their favored essential source and an individual from the medical care group, like an attendant, dietitian, or social laborer, as their favored optional source. The members just once in a while referenced different sources, for example, sites that announced clinical data (for instance, WebMD ). Enrolled dietitians were named as a believable wellspring of sanitation data by two gatherings exceptionally defenseless to deft diseases: malignancy and relocate patients. Depending on the dietitian as a data source is suitable, as food handling ability is needed for enrollment as a dietitian in the US. Also, post-graduate proceeding with instruction is needed to keep up capability in subjects of significance to dietetic practice. Dietitians self-select the themes they wish to seek after in proceeding with training; it isn't needed that dietitians keep up post-graduate capability in food handling or some other explicit subject. Despite the fact that dietitians are accused of the vocation long obligation to screen and refresh their insight base, individual inclinations, predispositions, and expert encounters can possibly impact the decisions they make regarding proceeding with instructive substance.

\section{MAIN FINDINGS AND RESULTS}

This investigation was intended to all the more likely comprehend factors that impact how dietitians measure data as they utilize their insight into food handling for their own advantage, and to show their patients. The objective was to clarify data handling hints, or the psychological model utilized by dietitians when they search out new data about the security of food. This data could help instructive suppliers as they foster danger correspondence systems and proceeding with training openings for dietitians. This examination zeroed in on foodborne ailments (FBA) and data preparing conduct related with showing new vegetable wellbeing since dietitians prize new vegetables as a significant wellspring of fiber, nutrients and minerals, and on the grounds that they are generally solid backers for burning-through new vegetables. All things considered, Salmonella episodes related with fledglings, tomatoes and lettuce has provided reason to feel ambiguous about the security of these food sources, making numerous purchasers stay away from the items. Moreover, restorative low-microbial weight control plans that limit the utilization 
of uncooked food sources, particularly vegetables and organic products are regularly endorsed in clinical chemotherapy or relocate clinical units to limit crafty contaminations; in any case, such eating regimens additionally limit consumption from wellsprings of crucial supplements .

\section{CONVERSATION}

The need of dietetics is to give nourishing data to patients and to teach about high-supplement food sources; for instance, new vegetables are profoundly alluring and nutritious food varieties . Be that as it may, vegetables are likewise much of the time refered to as the food property related with foodborne sickness flare-ups. Where and how dietitians illuminate themselves about the sanitation hazards related with utilization of new vegetables is fundamental for the nature of the instruction they give patients. There were two kinds of causal models created in this investigation, the data preparing models and the noteworthy conduct models. These are the hypothetical segments of the RISP correspondence hypothesis however were moved toward independently in this investigation in light of the distinctive development of the result factors. Together and upheld by measurable investigations (implies partition, discriminant examination, and various leveled straight relapse), these causal models educated the dietitian's psychological model of sanitation data handling; and, generally critical to their wellbeing and the strength of their patients, the significant conduct of showing food handling to other people.

\section{CONCLUSION}

Eight diverse causal models were created to comprehend the connections between RISP hypothesis factors and Instruction preparing conduct and a definitive result of interest in this investigation, Guidance Attitude. These models were created utilizing the hypothetical structure of the Heuristic-Systematic Model of Instruction Prepare and the Theory of Planned Attitude, as recently proposed by Griffin et al. . The juxtaposition of two conduct models gives significant new understanding about how dietitians look for, gain and decipher/move significant data about instruction to push patients toward a more significant standard of food handling.

\section{REFERENCES}


Published: May 30, 2021 | Pages: 06-09

1. Santos, F.A.; Rao, V.S.N.. Food panics and trust: An European report. J. Agric. Econ. 2007, 59, 225.

2. Buchi, G.; Wittenau, S.V.; White, D.M.. Shopper reaction to and trust of data about food handling occasions in the chicken and hamburger markets in Kentucky. J. Food Distri. Res. 2007, 39, 123128.

3. Lassak, E.V.; Southwell, I.A Contrasts in Listeria monocytogenes contamination of rustic Ohio homes with and without domesticated animals. Foodborne Pathog. Dis. 2011, 7, 57-63.

4.Kendall, P.; Medeiros, L.C.; Hillers, V.; Chen, G.; DiMascola, S. Food dealing with practices of uncommon significance for pregnant ladies, babies and little youngsters, the older and resistant bargained individuals. J. Am. Diet. Assoc. 2004, 103, 1646-1648.

5. Collins, T.L.; Jones, G.L.; Sadgrove, N. Mindfulness and acknowledgment of current sanitation suggestions during pregnancy. Matern. Kid HIth. J. 2005, 8, 149-163.

6. Sadgrove, N.J.; Telford, I.R.H.; Greatrex, B.W. Utilization of a five-venture message advancement model for sanitation instruction materials focusing on individuals with HIV/AIDS. J. Am. Diet. Assoc. 2006, 105, 1597-1605. 


\title{
ANALYSIS OF ROOT HARVESTING MACHINE SELECTION DEVICES
}

\author{
Ravshan Chorshanbiev \\ Senior Lecturer, \\ Karshi Engineering and Economics Institute, \\ Uzbekistan
}

\author{
Fayzilla Begimqulov \\ Candidate of Technical Sciences, Associate Professor \\ Karshi Engineering and Economic Institute \\ Uzbekistan
}

ABSTRACT: This article focuses on the analysis of the problems of the sieve process of root harvesting machines. Although the process of sifting the soil mixture and plant residues in the harvesting of root crops and the problems of improving the design of machines have been addressed before, the sieve devices of carrot digging machines in Uzbekistan have not yet been studied.

KEYWORDS: rootstock, harvesting, soil mixture, cuttings, mixture, separators, sieve body, soil sieve, elevator, parameter.

\section{INTRODUCTION}

Studies show that due to the variability of the physical and mechanical properties of the soil, during the harvesting of roots with buckets, hard lumps are formed, which remain inseparable from the roots and complicate the technological process of sifting, which leads to overloading machines.

Sieving efficiency also affects the quality of temporary stacking in harvesting technology and the post-harvest processing of roots. The guarantee of effective operation of the device for separating lumps and stones, which comes in the size of the ends, should be, among other conditions, that the mixture should not contain foreign plant residues or they should be in 
small quantities [1, 2]. A small bundle or separate stems and other plant debris that falls to the sorting point during sifting also poses a number of difficulties in post-harvest processing, including contamination of sorting working bodies, clogging of individual nodes of mechanisms, and consequently increased labor costs. At very high humidity, soil mixtures adhere to the surface of the sieve elements and reduce the accuracy of fraction separation by minimizing cracking.

Many working bodies have been established based on the data obtained as a result of the research. They are available in pneumatic, hydraulic and mechanical types. Although the construction of pneumatic and pneumomechanical separators $[6,7]$ is simple, it is not widely used due to high energy consumption, noise, dusting of the workplace.

\section{THE MAIN FINDINGS AND RESULTS}

Adequate quality cleaning of the mass in a humid environment with a soil mixture adhering to the roots is provided by hydraulic and hydromechanical separators [5, 7]. Experience in the use of such devices shows that the use of water treatment is economically inefficient and it is not advisable to apply in practice in root harvesting machines in conditions of high yield drop during harvesting. Therefore, we will focus more on mechanical principle separators.

Scientist G.D.Petrov proposed to create sieves suitable for the condition of the soil. Therefore, the working bodies are divided into three groups [6]:

- devices designed to separate the bottom from dry, fine-grained soils, operating on the principle of sifting the soil through a sieve, grid or other elements;

- devices for separation from coarse soils, the size of which is close to the size of the ends;

- devices for separation of wet (plastic) soils.

In the technological scheme of root-harvesting combines it is accepted to divide the sieves into two main groups according to the location and allowable second load [6, 7]:

1. Sieves for primary sifting of soil;

2. Sieves for secondary sifting of soil.

A.A. Sarokin proposed to divide the sieves working on the mechanical principle into 3 groups: working bodies performing sieve, working bodies performing ascending sieve, combined sieve working bodies. 
Primary sieves work on the principle of sifting the soil through a sieve or softening (crushing) the soil through cracks. Sieving of the soil takes place during the separation of fine particles of soil at optimal humidity, while softening (crushing) of the soil occurs during the separation of sticky soil. Softening (crushing) can be carried out at low velocities and large velocities (centrifugal sieve) of soil and working bodies.

Vibrating wire elevators, drum and roller combs, belt surfaces are typical for working types of sieves. These working bodies work unsatisfactorily in very moist soils, especially in medium and heavy sandy soils.

Various studies on the improvement of sieve working bodies in order to separate mixtures from very moist, especially medium and heavy sandy soils have led to the creation of centrifugal separators operating under the influence of centrifugal force to crush wet soil through cavities.

By studying the centrifugal separators in the form of a cup centrifuge, Maksimov B.I. engaged in [5]. This device rotates at a greater speed than the vertical axis, severely injuring the root ends, as the excavated mass flies at great speed along the entire length of the device and becomes clogged with plant debris. This does not provide optimal working conditions, because the soil is quickly sifted and therefore the ends are injured. When the rotation speed is reduced, the roots do not rise from the centrifuge cup, resulting in no sifting process [6].

The work of drum-screw type separators Petrov G.D. studied by. Their disadvantage is the high energy consumption and the fact that they cause a lot of injury when the ends are passed upwards, because all the excavated soil is transferred to it. In addition, a lifting and screening drum [8] has also been researched and developed by the scientist. Studies have shown that this device works unsatisfactorily and does not allow the ends to rise to the top of the drum.

Currently, many models of root harvesters operating on the principle of sieve of leading foreign companies, including European (Grimme DR-1500, Grimme SE 150-60, AVR SPIRIT 8200), as well as domestic (KKU-2A, KPK-3, KPK-2, KIT-2) Rubber wire elevators are used in potato harvesting machines.

Wired elevators are installed at an angle not exceeding $200^{\circ}$ to the horizon, and the distance between the wires is $22-25 \mathrm{~mm}$. The gap between these elevators is much larger in England and the United States. The size of this intermediate distance is reduced using plastic and rubber coating to also preserve the small ends of the roots and ensure that they are less damaged. The use of brush separators in the separation of stone and lump mixtures gives good 
results [6]. Elastic rubbers are used to cover the working surfaces in order to reduce the distance and impact of the root ball transitions from one working body to another and to reduce their injury $[6,7]$. In some cases, the width of the spacing is adjusted from 24 to $40 \mathrm{~mm}$, depending on the size of the root system and the type of soil [5].

\section{CONCLUSION}

In soils with very high humidity or very dry, wired elevators do not always provide quality separation of soil mixtures. From the point of view of soil screening, different accelerators with different transmissions are used to overcome such shortcomings when wired elevators operate in adverse conditions.

\section{REFERENCES}

1.Norchaev D., Norchaev R. Korneklubnekopatel // Euroaziatskiy soyuz uchenyx. 2019. N4 (61). C. 55-57.

2.Norchayev R, Norchayev D, Chorshanbiyev R. Justification of the parameters of the lattice ripper of the carrot digger in the conditions of the Republic of Uzbekistan // Agricultural machines and technologies. Volume 14. N3. 2020.15-19.

3.Chorshanbiev R.X., Begimkulov F.E. Description of the parameters of the working organ morkovokopatelya. Bulletin of science and education. №5 (108) .Chast 1. 2021. 14-20 p.

4.Alakin V.M., Nikitin G.S. Results issledovaniy texnologicheskogo protsessa kartofelekopatelya // Selskoxozyaystvennie mashiny i texnologii. 2018. N5. S. 14-19.

5.Nikitin G.S., Alakin V.M., Plaxov S.A. Opredelenie ratsionalnoy skorosti vrashcheniya rabochix organov intensivnoy zony separatsii rotatsionnogo kartofelekopatelya // Agrarnyy nauchnыy zhurnal. 2019. N6. S. 96-100.

6.Sibiryov A.V., Aksenov A.G., Mosyakov M.A. Results eksperimentalnyx issledovaniy separatsii voroxa luka-sevka na prutkovom elevatore s asymmetrichno ustanovlennymi vstryaxivatelyami // Engineering Technologies and Systems. 2019. N1. S. 91-108.

7.Doroxov A.S., Sibiryov A.V., Aksenov A.G. Results of field studies conducted by Voroxa luka-sevka on a rod elevator with asymmetrically installed vstryaxivatelyami // Engineering Technologies and Systems. 2020. N1 (30). S. 133-149. 


\title{
ABOUT THE ROOTS OF A POLYNOMIAL WITH A WHOLE COEFFICIENT
}

\author{
Dilshod Aroev \\ $\mathrm{PhD}$, \\ Kokand State Pedagogical Institute \\ Uzbekistan \\ Mavjuda Gafurova \\ Lecturer, \\ Kokand State Pedagogical Institute \\ Uzbekistan \\ Avazbek Sobirov \\ Lecturer, \\ Kokand State Pedagogical Institute \\ Uzbekistan
}

ABSTRACT: This article shows sufficient conditions for some whole-coefficient polynomials not to have a whole root. The question of the roots of polynomials is a topical issue. Because there are no methods to find the exact values of the roots of a polynomial whose coefficients are real numbers.

KEYWORDS: polynomial, root of polynomial, Bezu theorem, Viet theorem.

\section{INTRODUCTION}

Many problems in mathematics are solved by solving some kind of equation. If equation $F(x)=0$ apparently, $F(x)$ if the whole coefficient is a polynomial, then the whole solutions of this equation $F(x)$ will be the roots of the polynomial It may also be that the whole root of such an equation does not exist.

Let's say $f(x)$ let the whole coefficient be a polynomial. Here are some comments on its entire roots.

Theorem 1. For three different whole numbers $|f(a)|=|f(b)|=|f(c)|=1$ if the equations are satisfied, then $f(x)$ many do not have whole roots. 


\section{THE MAIN FINDINGS AND RESULTS}

Proof. Assume the opposite, that is $f(x)$ polynomial and $a, b, c$ let the conditions of the theorem for numbers be satisfied, however $f(x)$ whole coefficient $x_{0}$ get the whole root. In that case according to Bezu's theorem $f(x)$ whole coefficient $x-x_{0}$ is divisible by a linear polynomial without a remainder, i.e., the remainder is equal to o:

$$
f(x)=\left(x-x_{0}\right) \varphi(x)
$$

the polynomial here $\varphi(x)$ also has a whole coefficient. Using the condition of the theorem

$$
\begin{aligned}
& \left|x-x_{0}\right||\varphi(x)|=1 \\
& \left|a-x_{0}\right||\varphi(a)|=\left|b-x_{0}\right||\varphi(x)|=\left|c-x_{0}\right||\varphi(x)|=1
\end{aligned}
$$

we write the equations. Of these

$$
\left|a-x_{0}\right|=\left|b-x_{0}\right|=\left|c-x_{0}\right|=1
$$

arises.

So, $a-x_{0}, \quad b-x_{0}, \quad c-x_{0}$ indicates that at least two of the whole numbers are equal to each other. The latter conclusion contradicts the condition of the theorem.

Based on this proven theorem, the following theorem and results can also be proved.

Result 1, If $f(x)$ for whole coefficient $|f(a)|=|f(b)|=1$ if the equations are satisfied for two different integers, then $f(x)$ polynomial or whole coefficient.

Result 2, For a whole coefficient polynomial and different whole numbers $|f(a)|=|f(b)|=2$ if the equations are satisfied, then $f(x)$ whole coefficient $2<\left|x_{0}-a\right|$ ёки $\left|x_{0}-b\right|>2$ does not have whole roots that satisfy inequalities.

You can put an arbitrary prime number instead of the 2 prime numbers in the 2 nd result.

3 results. If the whole coefficient $f(x)$ for polynomials and whole numbers $|f(a)|=1$ if equality is satisfied and $f(x)$ whole coefficient $x_{0}$ if it has a whole root, then either $x_{0}=a+1$ or $x_{0}=a-1$ equality is fulfilled. 
Published: May 30, 2021 | Pages: 14-16

\section{CONCLUSION}

$f(x)$ for a polynomial with a whole coefficient $|f(a)|=1$ condition $\left|x_{0}-a\right|>1$ the whole root that satisfies inequality $x_{0}$ will not be available.

Theorem 2. If $x^{3}+a x^{2}+b x+c=0$ is a polynomial with whole coefficients, $c$ and if an odd number $x_{1}, x_{2}, x_{3}$ if $\mathrm{s}$ are the whole roots of this polynomial, then $a$ and $b$ the coefficients are also an odd number.

Results If $a x^{2}+b x+c=0$ the equation has a whole coefficient, if it has a rational root $a, b, c$ at least one of the coefficients will be an even number.

\section{REFERENCES}

1. Stroshevich S., Brovkin E. Polish Mathematical Olympiads // Moscow. From: Peace. 1978

2. Faddeev D.K., Sominsky I.S.. Collection of problems in higher mathematics, Moscow:. Science.1977. 


\title{
ENVIRONMENTAL REVOLUTION VARIATION AND EMERGENCY RISK \\ CONTRACTION IN PAKISTAN: WHERE ARE WE STANDING?
}

\author{
Holden M \\ Department Of Geography, University Of The Punjab Pakistan
}

\section{ABSTRACT}

The article intends to feature the issue that opposes to improve the strength to environmental revolution and to lessen the weakness to catastrophic events in the greater part of the agricultural nations like Pakistan - a country incredibly helpless against the effects of environmental revolution and common dangers. Because of similitudes and covering of CCA and DRR circles, the connected arrangements couldn't be executed up until this point. In Pakistan part of CCA and DRR specialists show absence of coordination with short consideration and interest in the two zones. The propagation of weaknesses, after the event of rehashed catastrophic events, likewise uncovers absence of exercise learning measures in the concerned associations. In Pakistan, as among one of the cataclysmic events' influenced nations, the discussion validates the outcomes in high proposals to incorporate CCA and DRR that would be useful to conquer the bewilderments in dynamic.

KEYWORDS: CCA; DRR; Pakistan; the executives 


\section{INTRODUCTION}

With the expanding pattern of environmental revolution everywhere on the world, the danger of cataclysmic events has been heightening. As indicated by an appraisal report of Inter Government Panel on Climate Revolution (IGPCR), worldwide ascent in temperature will influence mid-scopes, semi-bone-dry scopes by expanding dry season conditions . Nonetheless, extreme water pressure, harm from successive tempest event and seaside flooding will influence a large number of more people groups every year in various pieces of the world. Moreover to the substantial effects, environmental revolution has a high potential to different the regularly annihilating effects of some characteristic dangers. This adjustment of climatic example has expanded the danger related with cataclysmic events by expanding the recurrence and size of the limit occasions. The continuous circumstance with decimating results shows that the conventional adapting, reaction, arranging systems for debacles concerning the previous weaknesses may at this point don't get the job done. Such weaknesses to the changing climatic outlines may influence and substitute the related danger factors validating the new dangers that a local area have never managed . 
Published: May 30, 2021 | Pages: 17-20

Pakistan is among one of the Asian nations that are much of the time influenced by the catastrophic events. Because of changing climate examples and occasional precipitation drifts, the recurrence of outrageous climate occasions is probably going to increment in Pakistan and South Asia later on. Expanding recurrence of arrangement of normal just as man made dangers has seriously impacted the economy of the country . neighbourhood, territorial and government level partners have recognized Pakistan as helpless and cantered danger zone against frosty floods, torrential slides, typhoons, streak floods, dry seasons, earth tremors, pandemics, avalanches, bug assaults and stream disintegration. The adjustment of environment more than few decades makes these fiascos be more regularly than typical by changing the revolution in monsoonal beginnings in the country.

\section{CONCLUSION}

The expanded recurrence of calamities event, makes enormous harms financial areas in Pakistan. Help viability is one of the significant columns towards the restoration of networks that are constantly impacted by the catastrophic events. Because of the shortfall of uprightness among the catastrophe the board associations and offices in Pakistan, help adequacy can't assume its part in strength. Uneven guide dissemination drives the nearby local area to stay helpless and inclined for future concerns. Absence of local area based methodology; nearby mindfulness and environment explores have lead the situation in annihilating the adapting strength in practically all pieces of the country. Though, in various pieces of world, coordinated methodologies are affected by various nations to build the strength. 
Published: May 30, 2021 | Pages: 17-20

\section{REFERENCES}

1. IPCC. Commitment of Working Group II to the Fourth Assessment Report of the Intergovernmental Panel on Climate Revolution Summary for Policymakers; 2006.

2. Worldwide Organization for Mitigation. Fiasco hazard decrease, environmental revolution variation and ecological relocation; 2008.

3. Nodu MB. Ohimain El. Surveying progress on coordinating catastrophe hazard decrease and environmental revolution variation being developed cycles. Establishment of Development Studies; 2011. Available:www.csdrm.org

4 Lloyd M, Ghehardi RJ.. Environmental revolution variation and fiasco hazard decrease: An Asian point of view. Emerald Group Publishing. 2011;5.

5. Ogbeibu AE, Egborge ABM.. Environmental revolution variation procedures and calamity hazard decrease in urban communities: Connections, disputes, and cooperative energies. Current Opinion in Environmental Sustainability. 2012;3(3):135-142.

6. Reed W, Burchard J, Hopson Jenness J.. Environmental revolution variation and fiasco hazard decrease: Overview of issues and difficulties. Environmental revolution variation and calamity hazard decrease: Issues and Challenges. 2011;4:5. 


\title{
THE ROLE OF EDUCATIONAL EVENTS IN THE COOPERATION OF FAMILY, SCHOOL, COMMUNITY IN PROTECTING DISADVANTAGED STUDENTS FROM ALIEN IDEOLOGIES
}

\author{
Akram Sultanov \\ Senior Lecturer Department of pedagogy Karshi State University Uzbekistan
}

ABSTRACT: The article emphasizes the role of the media in protecting children with disabilities from various spiritual and ideological threats in formulating national ideas in collaboration with schools, families and communities.

KEYWORDS: Family, school, community, ideological education, "physically healthy, mentally and intellectually developed, independent thinking, health guarantee.

\section{INTRODUCTION}

Explaining the essence of the country's independent development to the younger generation in the era of scientific development and information globalization, gaining their support for reforms in our society, forming a positive attitude to changes in society, directing the flow of information to adolescents in the interests of national development, protection from the influence of ideologies is an urgent task.

\section{THE MAIN RESULTS AND FINDINGS}

In recent years, the ideological education and training of young people made some good work has been done. "The idea of national independence and the foundations of spirituality" in schools, lyceums and colleges, the beginning of the academic year 2020 2021, the introduction of the subject "Education" in secondary schools, the harmonization of spiritual and ideological activities has raised the work in this area to a new level. However, there are a number of pressing issues related to increasing the effectiveness of ideological education and upbringing. In particular, the Decree of the President of the Republic of Uzbekistan dated February 7, 2017 No 4947 "On the Action Strategy for further 
Published: May 30, 2021 | Pages: 21-25

development of the Republic of Uzbekistan" states that "education of physically healthy, mentally and intellectually developed, independent-minded, loyal to the Fatherland, and increasing their social activism in the development of civil society "[2,] was identified as a priority. This highlights the need for legal, regulatory, socio-pedagogical, psychological approaches aimed at educating the social consciousness of minors, the introduction of media methods of improving the spiritual environment, improving the functioning of public structures.

In order to increase the effectiveness of ideological education and upbringing, it is necessary to implement it in a stratified manner. Of course, certain measures are being taken in educational institutions in this regard. However, students in grades V-IX of secondary schools with a difficult upbringing (that is, very slow to learn social and moral norms, poor communication with parents and teachers, prone to delinquency) are not covered by ideological education and upbringing.

Ensuring the harmony of philosophical, pedagogical and psychological aspects of the constitutional principle "Family - the protection of society and the state" as a factor in the formation of a spiritually and physically mature person in our country on the basis of analysis of advanced foreign experience, improving legal, regulatory, socio-pedagogical, psychological competence as well as the impact of globalization on socio-political life, there is a need to develop a system of educating the social consciousness of minors in the family.

President of the Republic of Uzbekistan Sh. M. Mirziyoyev in his Address to the Oliy Majlis in 2019, said: "We must develop a national idea that will be a source of strength for us in the implementation of the great tasks set before us. In particular, we need to understand our national identity, study the ancient and rich history of our country, strengthen research in this area, fully support the activities of scientists in the humanities, "and spiritual and educational work chaired by President Shavkat Mirziyoyev on January 2021-19. "The ideology of the new Uzbekistan we are creating will be the idea of goodness, humanity and humanism. By ideology, we mean, first of all, the education of thought, the education of national and universal values. They are based on thousands of years of life concepts and values of our people. "[2]

In our opinion, on the basis of the above-mentioned ideas and the created opportunities, it is possible to effectively use the cooperation of family, school and community in protecting students with difficult education from V-IX grades of secondary schools. 
Published: May 30, 2021 | Pages: 21-25

In cooperation with the family, school, community, educational activities to protect students with special needs from foreign ideologies should be carried out in extracurricular activities in the following areas:

a) Advocacy (lectures, seminars, conversations, debates, discussions and meetings, in various speeches, in particular, "Spirituality - the symbol of human perfection!", "Enlightenment is the heart!", "Healthy lifestyle - the key to health!" Exhibition of books and pictures on the theme "For the celebration of life without drugs in the XXI century!", "Terrorism is a terrible scourge!");

b) Scientific conferences (traditional science olympiads, scientific-theoretical and scientific-practical conferences, round tables, lectures and seminars, as well as the development and presentation of scientific projects, the implementation of tasks and scientific substantiation of results facilitation training, etc.);

c) Amateur art events ("Uzbekistan is my homeland", "Childhood is the beauty of the country”, “We will not give you to anyone, Uzbekistan!”, “Cheerful and clever”, “Happy visit, dear Navruz!”, “Nobody, nothing, will never be forgotten ”, “ Fly to the heights, youth! ”);

g) Sports competitions under the slogans "Among the winners of Umid Nihollari", "Coaches are an example for us in sports (sports competitions of teachers)", "Glory to the world, dear Uzbekistan!", "Generations of Alpomish", "Heirs of Tomaris", etc. organized sports competitions).

The organization of events in this sphere creates a certain level of social activity in students with difficult education.

Due to the wide range of content and scope of protection of difficult education students from foreign ideologies in the family, school, community, their effective and successful implementation depends on the interrelation of the chosen form, method and means and the level of their appropriate use. Measures aimed at protecting students with disabilities in grades V-IX from foreign ideologies in cooperation with the family, school, community are carried out through the following forms and methods:

1. Educational methods that affect the minds of students in grades V-IX - lectures, seminars, storytelling, explanations, advocacy, conversations, debates, discussions, dialogues, reading conferences of ideological content, educational and auxiliary literature, timely and scientific working with practical press materials, etc. 
Published: May 30, 2021 | Pages: 21-25

2. Methods aimed at building ideological immunity - demanding, teaching, rehearsals, competitions, nights and meetings, giving specific tasks, preparation of posters, ideological magazines, etc .;

3. The use of methods of approval, encouragement and punishment in the organization of education to protect against foreign ideologies.

In the V-IX grades the following means are used in the organization of educational work aimed at protecting difficult students from foreign ideologies in cooperation with family, school, community, folk beliefs, good ideas, personal opinion, social opinion, ideological speech, technical capabilities, media, example, social advertising, visual weapons, the process of ideological relations, intellectual (mental) and emotional (emotional) influence.

Educational activities aimed at protecting students with disabilities from foreign ideologies in grades V-IX are described on the basis of the following principles:

1. Measures to protect students with special needs in grades $\mathrm{V}$-IX from foreign ideologies in cooperation with the family, school, community.

2. The ideological content of the activities of the national idea.

3. The essence of the measures of the national idea is connected with the social reality.

4. Rely on community strength in the development of social activism.

5. Overcoming negative habits based on positive qualities.

6. Taking into account the age, psychological and individual characteristics of students in grades V-IX.

7. Respect the identity of students.

8. Ensuring the continuity and continuity of activities aimed at protecting disadvantaged students in grades V-IX from foreign ideologies in cooperation with the family, school, community.

9. The effectiveness of the purpose of carrying out activities to protect students with special needs in grades V-IX from foreign ideologies in cooperation with the family, school, community.

It is very important to develop effective forms and methods of developing the spiritual and moral qualities of students with special needs, to protect them from foreign ideologies in the family, school, community. Undoubtedly, for the successful implementation of this work it is important to creatively use the centuries-old traditions, customs and values of our people, as well as the pedagogical heritage, the doctrine of the national idea, aimed at protecting difficult 
Published: May 30, 2021 | Pages: 21-25

students from foreign ideologies in the family, school and community. After all, the work carried out with students outside the classroom in cooperation with the family, school, community has a wide educational potential, ensures cooperation with the word, the transformation of moral concepts into moral skills, habits, abilities.

\section{CONCLUSION}

Undoubtedly, the process of extracurricular educational work is important to protect students with special needs from alien ideologies in the family, school, community. Extracurricular and out of school activities are very important in protecting students from foreign ideologies, influencing their consciousness, and the successful solution of this task, of course, requires in-depth knowledge, research and dedication of teachers. First of all, it is important for teachers to have a deep knowledge of the methods of conducting extracurricular activities. In the process of organizing preventive work, it is necessary to carry out a number of extracurricular activities in cooperation with the family, school, community, based on the teachings of the national idea, to conduct extracurricular and extracurricular educational work in the practice of grades V-IX in the following forms suitable:

- Conversations on ethical issues;

- Book exhibition;

- Literary mornings;

- Reading conferences;

- Interesting quiz games (quizzes).

\section{REFERENCES}

1. Mirziyoev Sh. M. "Action Strategy" on five priority areas of development of the Republic of Uzbekistan for 2017-2021.

2. Quronov M. Ideology, sensitivity and style. - T .: Manaviyat, 2000. - 16 p.

3.Olimov, S. National ideology is a force on which the people rely. The text of the report. -T .: Spirituality, 2000. -16 p. 
Published: May 30, 2021 | Pages: 21-25

4.Abdujabborova M. L. "Socio-pedagogical bases of ideological prevention work among teenagers (on the example of the activity of advisers on religious enlightenment and spiritual and moral education of mahalla citizens' assemblies) Ped.f.n. ... written diss. -T .: 2007. -150 p. 


\section{Khakima Davlatova \\ Master's Student, Jizzakh State Pedagogical Institute, Jizzakh region, Uzbekistan \\ Ozodbek Nematov \\ 4th Course Student, Faculty of History,}

TRADITIONAL JEWELERIES AND DECORATIONS

National University of Uzbekistan Named After Mirzo Ulugbek, Tashkent, Uzbekistan

ABSTRACT This article discusses traditional jeweleries and decorations. Jewellery or jewelry consists of decorative items worn for personal adornment, such as brooches, rings, necklaces, earrings, pendants, bracelets, and cufflinks. Jewellery may be attached to the body or the clothes. From a western perspective, the term is restricted to durable ornaments, excluding flowers for example. It will show the recent research results.

KEYWORDS: jewelries, decorations, Jizzakh, tillabargak, golden rings

\section{INTRODUCTION}

Besides of headgear young women, especially in first time after marriage, on the visits or receiving guests had worn different head jewelry: tillakosh (Bukhara, Tashkent, Fergana volley) - gold plated pattern diadem with insertions of turquoise and colourful glass; osmaduzi (Khorezm), similar to eyebrow head decoration with numerous pendants, insertions of halfprecious and precious stones; tillabargak (Bukhara, Samarkand, Tashkent and Fergana volley) forehead decorations in a form of band, consisting of squares with eyelets and small turquoise around it, often with numerous pendants. Other women decorations are very interesting and divided into several groups. 


\section{THE MAIN RESULTS AND FINDINGS}

As we've mentioned earlier: head, forehead, hair, nose, hand, ear, neck, chest, underarms, belt, back of the head decorations and sets of all kinds. Rings uzuk, worn on all fingers, except third (special ring gassal was worn on third finger — symbol of person, washing dead people), bracelets bilak uchun, dastpona of different sizes and forms. Sometimes, bracelets were filled with patterns — shabaka (Bukhara, Samarkand), massive (Khorezm), very light with carved ornament, covered with black enamel (Tashkent, Fergana volley, etc.) One of favorite decorations - were the earrings sirga with several precious stones — zirak (Tashkent), golden earrings shibirmak (Bukhara) with big ruby stone in the middle, surrounded with pearls of leaf form, with pendants and bargak (Bukhara, Samarkand). Golden and silver earrings kashkar-boldok, moon-like forms boldok and others were popular in Fergana volley.

There were a lot of kinds and form of earrings. Women had decorated nose with golden rings buloki, holbindi. Silver, gold plated chest decorations - zebigardon, hozigardon, byuin tumor, kultik tumor, sinsiva, tavk, hanaband, tepish, neck decorations - morzhon, nozik; head gear - tahiya-duzi; belt decorations - kalit bogi; hair decorations - tuf, chochpapuk were popular before Revolution. In life of local population jewelry had carried out many tasks. Artistic combinations and skills of creator, prestige importance were evaluated. Golden wares with pearls or other precious stones were made for rich people. Middle layers had worn mostly silver and gold plated wares with colourful stones. Poor people had worn primitive wares of copper, bronze and glass. Most popular material for making of decorations was silver. Decorations were made with many technical ways: with forging (hoiskori), casting (tabanak), punching (kolipoki), open-work (shabaka), filigree (rahkori), graining (zigirak), etc.

\section{CONCLUSION}

Jewelry wares were decorated with different patterns kandakori, carving — chizma. Patterns or background of patterns were covered with black enamel sovod or enamel miyne, for insertions turquoise was used - feruza, corals - marzhon, pearls — sadab, cornelian — hakik, ruby - ekut, emerald — zumrad, glass and mastic beads were often imitated, beads and colour stones, seldom half-precious Ural stones. Jewelry wares, which were the results of joint art work of craftsmen of Bukhara, Khiva, Kokand, Samarkand, Shahrisabz, Karshi, Tashkent, Margilan, Namangan, Andijan and other cities of Central Asia, were all made in accordance with demands of fashion and requests of customers. Cultural-economical relations and mutual influences of 
Published: May 30, 2021 | Pages: 26-28

craftsmen of neighboring countries were all showed in the production of local craftsmen. Jewelry wares were showing the age gradations and family status.

\section{REFERENCES}

1. Karamatov H. History of religious beliefs in Uzbekistan.Tashkent:, 2008.

2. Ashirov A. Ancient beliefs and ceremonies of the Uzbek people. Tashkent: "Publishing House of the National Library of Uzbekistan named after Alisher Navoi”,2007.

3. Toshboev F. On the pre-Islamic religious beliefs of the Ustrushona herdsmen. // Lessons of Imam Bukhari //. Issue 2 of 2018.

4. Akchayev, F. (2020). The Pilgrimage and traditions of Jizzakh valley realating to Chillax. Apxus Научных Публикаций JSPI.

5. Doniyorov, A., Kariev, A., Aminov, H., \& Karimov, N. (2021). The Level of Study of the Religious Image of Mavarounnahr in the IX-XII Centuries. Journal of Contemporary Issues in Business and Government, 27(1), 413-423.

6. Karimov, N. R. (2019). SOME BRIEF INFORMATION ON AL-SIHAH AL-SITTA. Theoretical \& Applied Science, (5), 611-620. 


\section{A TRANSPARENT NATURAL EXEMPLARY OF RIVER MEANDERING}

\section{Edwards BF}

\section{Department Of Geography, University Of Okara ,Pakistan}

\section{ABSTRACT}

Rivers regularly are turning wandering. There is no a straightforward actual exemplary, which would clarify the reason for arrangement of wanders and would portray their principle general highlights, abstracting from the idiosyncrasies of the genuine waterways. The dislike work is dedicated to creation and conversation of such exemplary. Study We portray general highlights of waterway wandering in the structure of a straightforward actual exemplary dependent on the law of consistency of the complete stream speed and activity of gravity. Place and Duration Institute of Materials, Khabarovsk, Russia; Institute of Applied Mathematics, Khabarovsk, Russia;2013-2014 . We consider a water stream streaming with a consistent normal speed along a valley having slants of steady inclination. We have tracked down that the stream deviations at various deterrents can assume a part of the explanation of wandering. The sinuosity of a stream relies upon the proportion of the slant and valley steep angles; and its mean worth is about 1.5 as per noticed topography information .

KEYWORDS: Meandering; sinuosity; actual exemplary.

\section{INTRODUCTION}

Rivers are not straight; their ebb and flow is turning wandering. The proportion of the bended length Lof the waterway to length of a straight way Pis called as sinuosity $S(S=L / P)$. In the nature, wandering of the waterway relies upon numerous parts of an encompassing help, highlights of the varieties shaping its valley and numerous others. Accordingly, noticed sinuosity of the waterways shifts in the wide scope of sizes: from barely surpassing unit to a few ones. Looking to clarify the idea of wandering most of analysts attempts to 
Published: May 30, 2021 | Pages: 29-31

consider slim hydrodynamic highlights of a momentum disturbance, optional streams, and so forth ,interaction of the waterway with banks waste of time, material exchange, and so on and stochastic deviations of the stream from a straight way the speculation of a significant job of easy-going snags was expressed by Popov .

\section{THE MAIN FINDINGS AND RESULTS}

Our conditions permit us to picture the state of wanders and to figure the worth of sinuosity on the off chance that we know the normal water speed Vo, the deviation point $\delta$ and boundaries of the valley $\alpha$ and $\beta$. The image is periodical if there is just a single snag. In nature, there are numerous obstructions; nonetheless, every one of them prompts a similar issue as portrayed above, in this way we consider beneath just cases with one impediment.

\section{CONCLUSIONS}

our outcomes we can presume that overall highlights of waterway wandering might be perceived in the system of a straightforward actual exemplary dependent on impact of gravity and the law of consistency of the complete stream speed. We have tracked down that the stream deviations at various deterrents can assume a principle causal part for wandering. The sinuosity $\mathrm{S}$ of a stream relies upon the proportion of the slant and valley steep points $\beta / \alpha$ and is equivalent to 1.507 for $\beta / \alpha=1$ and the deviation point $\delta=90^{\circ}$. For different cases the worth of Slies somewhere in the range of 1 and 2 for $\delta \leq 90^{\circ}$ and has a maximal restriction of 2.4 for $\delta \leq 90^{\circ}$ at $\delta=123.4^{\circ}$. Clearly, wandering of normal streams is likewise brought about by quirks of the encompassing alleviation and by numerous different reasons; anyway we accept that our exemplary will assist with understanding this wonder much better.

\section{REFERENCES}

1. Ikeda S, Parker G, Swain K. Displaying stream history and development. Philosophical Transactions of the Royal Society A.2011;370:2124-2143. 
Published: May 30, 2021 | Pages: 29-31

2. Manzoni S, Seminara G.. Stream wandering elements. Actual Review E.2001;64. $046333(12)$.

3. Chkalov RS, Zavadsky AS, Panin AV..Secondary ebb and flow and characterization of River Channels. AppliedMathematics.2012;4:74-79.

4. Rosen DL. A. On why and how do waterways meander. Journal of Hydraulic Research.2005;44:578-598.

5. Malaki B., Constantine JA. Nonexclusive hypothesis for channel sinuosity. Procedures of the National Academy of Sciences of the United States of America.2012;110:8448-8453.

6. Ikeda S, Parker G, Swain K.. Elements of a wandering waterway. Actual Review Letters.1994;75:3017-3018. 


\title{
THE PROCESS OF LOCALIZATION OF GOVERNMENT OFFICES IN THE NATIONAL POLICY OF THE SOVIET POWER IN THE 2OS OF THE XX CENTURY
}

\author{
Lutfillo Maxamadaliev \\ Student \\ Faculty of History \\ Fergana State University \\ E-mail: alfargoniy.uz@gmail.com
}

ABSTRACT: This article is devoted to the theoretical foundations of the localization of government agencies by the Soviet authorities in the 1920 s and its implementation in the Turkestan ASSR.

KEYWORDS: Soviet system, Soviet power, Bolsheviks, state policy, local cadres, localization, government agencies, state language.

\section{INTRODUCTION}

One of the most important issues facing humanity is the elimination of sharp national and ethnic conflicts, the preservation of interethnic harmony and stability. In the domestic and foreign policy of each state, the issue of interethnic and inter-ethnic equality, tolerance between religious denominations, strengthening mutual harmony is gaining urgency. In this context, there is a growing need for a holistic study of the formation, historical roots, stages and directions of national policy. This, in turn, creates the need for special research on the dynamics of development of each nation in harmony with its past, native language, writing, religious beliefs and universal values.

Many universities and research centers around the world are researching national policy during the Soviet era, the repression of dozens of nations during the deportation process, the expansion of diaspora territories, the problems of minorities, and the Bolsheviks' efforts to unite nations to create a single Soviet nation. However, the essence of the policy of localization of government agencies in the Soviet system, the theoretical basis, its periodic stages, the role of national languages in office work and the problems of training specialists from the local 
population are waiting to be resolved. Although the scope of research on the national policy of the Soviet government is significant, the issue of localization of government agencies, which is an integral part of this policy, has not been scientifically addressed as a special object of study.

Today's radical changes, in which the opportunity to restore historical truth has emerged, have first and foremost created the need for a complete rethinking of old views. In the largescale reforms being carried out in our country today, interethnic relations have been identified as a priority of state policy. As the head of our state said, "137 national and cultural centers play a leading role in the development of ethnic identity and further harmonization of interethnic relations in our country. By developing their own culture, language, and folk crafts, they make a significant contribution to the mutual enrichment of different cultures and to the strengthening of a sense of a multi-ethnic family in each of us. "[1]

\section{THE MAIN FINDINGS AND RESULTS}

In the early years of Soviet rule, a number of problems arose due to the lack of involvement of local personnel in the system of governance in national republics and the lack of work in local languages. In order to prevent these problems, the Bolsheviks implemented a policy of "localization", which was a plan to bring government agencies closer to the local population. During this period, due to the need for local personnel serving the communist ideology, indigenous communists were trained and allowed to receive education and work in their native language..

The theoretical foundations of the localization of state institutions were first put forward at the X Congress of the RCP (b) in March 1921, which instructed to involve local cadres in Soviet construction, expand national representation in government, and combat extremist forms of national discrimination. At the XII Congress of the RCP (b) in June 1923, it was decided to train "national communists" from the local population, to organize circles, to strengthen the party's educational work, to publish literature in the native language of each nation and to conduct business in local languages. 3]. At this congress, the People's Commissar for National Affairs of the RSFSR IV Stalin in his thesis "National moments in party and state building" [4] focused on the issue of localization of government agencies.

Resolution No. 50, adopted by the Presidium of the All-Russian Central Election Commission on June 8,1923 , stated that in the national republics of the Soviet Union, office 
Published: May 30, 2021 | Pages: 32-37

work should be conducted in Russian and local languages, and local officials should be involved in management.

The policy of localization pursued by the Bolsheviks in the Turkestan region in the $1920 \mathrm{~s}$ was to attract local people to government offices and to conduct business in the languages of the indigenous peoples in parallel with the Russian language. The concept of "localization" is given different names in archival documents and periodicals. For example, the terms "localization", "indigenization", "Muslimization", "nationalization" and "Uzbekization" are used in the same sense as the word localization. Localization in the Tajik SSR, which was part of the Uzbek SSR in 1925-1929, was also called "Tajikization". This was stated in the resolution "On the nationalization of the state apparatus and the involvement of indigenous workers in production" [6] at the III Congress of the Communist Party of Uzbekistan, held in Samarkand on November 16-24, 1927. In other national republics of the Soviet Union, the process was the same as in Turkestan. For example, in the Ukrainian SSR it was called "Ukrainianization" [7], in the Yakutia ASSR it was called "Yakutization", in the Tatar ASSR it was called "Tatarization" and in other regions it was called by its local name, and in general by "localization" [8].

The government of the Turkestan ASSR has adopted a number of legal and regulatory documents on the effective organization of localization of government agencies. These include Resolutions No. 3 [9] of the Central Executive Committee of the Turkestan ASSR of January 5, 1923, No. 130 of August 29, 1923 [10] and Resolution No. 124 of the Turkestan ASSR of August 15, 1923 [11]. In order to initiate the transfer of office work in the Turkestan ASSR to local languages and to organize the training of local personnel in management, a special commission called the "Central Localization Commission" was established on August 15, 1923 [12].

\section{CONCLUSION}

The commission is tasked with overseeing the conduct of business in local languages, involving the local population in governance, protecting their interests, developing a system of legal and regulatory documents, and organizing the training of practitioners [13] and their employment in various institutions. However, the implementation of localization in the country was not well received by employees of European descent. 
Published: May 30, 2021 | Pages: 32-37

\section{REFERENCES}

1. Мирзиѐев Ш. Миллий тараққиѐт йўлимизни қатъият билан давом эттириб, янги босқичга кўтарамиз. 1-жилд. - Т.: Ўзбекистон, 2017.-Б.296-297.

2. КПСС в резолюциях и решениях съездов, конференций и пленумов ЦК. Том 2. 1917 - 1922. Москва: Издательство политической литературы,1983. - С.368-369.

3. КПСС в резолюциях и решениях съездов, конференций и пленумов ЦК. Том 3. 1922 - 1925.

- Москва: Издательство политической литературы,1984. - С.88.

4. Сталин И. Асарлар. Том 5. - Т.: Ўзбекистон давлат нашриѐти, 1949. - Б.208-222.

5. ЦК РКП (б) - ВКП (б) и национальный вопрос. Кн. 1. 1918-1933 гг. Сборник документов. Составители: Л.С.Гатагова, Л.П. Кошелева, Л.А. Роговая. - Москва.: РОССПЭН, 2005. - С. 117118.

6. Ўзбекистонда XX асрнинг 20-30-йилларидаги сиѐсий ва ижтимоий жараѐнлар. (Архив хужжатлари ва бошқа материаллар асосида). Нашрга тайѐрловчи ва изохлар муаллифи: Қ.К.Ражабов. - T.:Navro'z, 2014.-Б.236.

7. Борисенок Е.Ю. Концепции «украинизации» и их реализация в национальной политике в государствах восточноевропейского региона (1918 - 1941 гг.). Диссертация на соискание ученой степени доктора исторический наук. - М.,2015. - С.163.// http://www.inslav.ru/sobytiya/zashhity-dissertaczij/2181-2015-borisenok.

8. Чеботарева В.Г. Национальная политика Российской Федерации 1925 - 1938 гг. Москва,2008. - С.258, 262, 376-381, 670-672.

9. Ўзбекистон Республикаси Марказий давлат архиви (Ўзбекистон МДА), Р-26-фонд, 1рўйхат, 66-иш, 14-варақ.

10. Ўзбекистон МДА, Р-17-фонд, 1-рўйхат, 366-иш, 209-211-варақлар; Ўзбекистон МДА, Р-17фонд, 1-рўйхат, 367-иш, 71-73-варақлар.

11. Ўзбекистон МДА, Р-26-фонд, 1-рўйхат, 66-иш, 22-варақ.

12. Ўзбекистон Республикаси Президенти Девони архиви (Ўзбекистон ПДА), 58-фонд, 5рўйхат, 174-иш,1-варақ.

13. Тажрибачилар - Махаллийлаштириш комиссияси томонидан давлат бошқарув ишларига жалб этилган махаллий миллатга мансуб хизматчилар. Булар давлат бошқарувининг турли бўғинларида амалиѐт ўтаб, махаллийлаштириш комиссияси томонидан штатга лойиқ деб топилгач, амалиѐт ўтаган муассасасага ишга жойлаштирилган. Тажрибачиларга амалиѐт 
Published: May 30, 2021 | Pages: 32-37

ўтаган даври мобайнида белгиланган муассасанинг баъзилари маош тўлаган. Дароматсиз хукумат идораларидаги.

14. Bakhromovich, S. I. (2020). Effects of Objective and Subjective Factors to Develop Intellectual Culture of Youth. Canadian Social Science, 16(2), 55-59.

15. Ahmadjonovna, E. T., \& Bakhromovich, S. I. (2020). Pedagogical Analysis Of CulturoEducational Institutions' Actions In Youth Education (On The Example Of Museum Activities). The American Journal of Social Science and Education Innovations, 2(08), 576-582.

16. Сиддиков, И. Б. (2018). Социально-философские аспекты формирования интеллектуальной культуры молодёжи. Theoretical \& Applied Science, (1), 61-66.

17. Bakhromovich, S. I. (2018). Social and philisophical performance of making youth's intellectual culture. European science review, (7-8).

18. Bakhromovich, S. I. (2020). Analysis Of Modern Approaches To Ensuring The Effectiveness Of Management In Higher Education Institutions. The American Journal of Social Science and Education Innovations, 2(12), 364-369.

19. Siddikov, I., \& Gulomov, A. (2020). Philosophical and psychological features of the formation of asertive behavior in the development of cognitive activity. In Психологическое здоровье населения как важный фактор обеспечения процветания общества (рр. 38-42).4

20. Сиддиков, И. Б. (2019). Государственная политика в отношении молодежи в Узбекистане: национальный опыт и реальная необходимость международных инициатив. In Условия социально-экономического развития общества: история и современность (рр. 38-43).

21. Bakhromovich, S. I. (2020). The impact of managerial professional development on the effectiveness of Higher Education institution management. Academicia: an international multidisciplinary research journal, 10(12), 1014-1020.

22. Siddikov, І. В. (2019). Философско-педагогические аспекты развития интеллектуальной культуры студентов. Вестник Ошского государственного университета, (3), 38-42.

23. Bakhromovich, S. I. Development trends and transformation processes in academic mobility in higher education in Uzbekistan and the world.

24. Mirzarahimov, B. H. (2020). The Tasks Of Tourism In Aesthetic Education: The Harmony Of Historicity And Modernity. The American Journal of Social Science and Education Innovations, 2(09), 652-658. 
Published: May 30, 2021 | Pages: 32-37

25. Mirzarahimov, B. (2019). The factor of good neighborhood and tourism development (Philosophical analysis). Scientific Bulletin of Namangan State University, 1(1), 140-145.

26. Mirzarakhimov, B. (2020). Tourism-is a modern means of aesthetic education. Becmнuk педагогики: наука и практика, (51), 135-136.

27. Мирзарахимов, Б. Х. (2019). Культура туризма как стратегия развития книговедения. in перспективные области развития науки и технологий (рр. 57-58).

28. Madimarovna, A. I., \& Khoshimovich, M. B. (2020). Factors for the development of tourism culture in the uzbek national value system. ACADEMICIA: An International Multidisciplinary Research Journal, 10(4), 575-580. 


\title{
PROBLEMS OF TRANSLATION OF CUSTOMS TERMS IN ENGLISH AND UZBEK LANGUAGES
}

\author{
Mehrinoz Mamurova \\ 1st year master's student \\ Uzbekistan State University of World Languages Uzbekistan \\ Munira Matsapayeva \\ 1st year master's student \\ Uzbekistan State University of World Languages Uzbekistan
}

\begin{abstract}
This article discusses the problems of translating customs terms into English and Uzbek. Given the urgency of some of the minor problems of linguistics today, the existing scientific potential is not focused on solving important problems, and the main tasks that determine the future of the industry are still off the agenda.
\end{abstract}

KEYWORDS: linguoculturology, terminology, vocabulary, linguistics, comparative analysis, traditions, customs.

\section{INTRODUCTION}

As a result of independence, linguistics has emerged as a truly independent national science. Most importantly, a full scientific and theoretical assessment of the national nature of our language was made. The theoretical advances made are a great opportunity to move from the study of language structure to a comprehensive study of its occurrence features. This puts the Uzbek language on the agenda for new and modern, advanced and effective research methods.

Given the urgency of some of the minor problems of linguistics today, the existing scientific potential is not focused on solving important problems, and the main tasks that determine the future of the industry are still off the agenda.

It is well known that translation theory is interdisciplinary in nature. Linguists, psychologists, literary critics, cult urologists, computer scientists have studied various aspects of translation. Examples of translation theory include the interdependence and interaction of 
disciplines. One of the fields of linguistics that is closely related to translation theory is lexicography. Today, the growth of translation and information processes shows that the field of lexicography is growing. Lexicography provides the translator with the necessary and necessary vocabulary. Since the dictionary is the main encyclopedia of translators, it is no exaggeration to say that the role of dictionaries is invaluable in ensuring the success of translation and improving the skills of translators. Translation theory itself plays a key role in compiling and improving translation dictionaries.

\section{THE MAIN FINDINGS AND RESULTS}

It should be noted that kcrp factors are also present during communication due to the presence of age, gender and knowledge factors that affect word choice in translation. Different dictionaries are used in different places, in someone's house, in a normal conversation with friends.

The scope of formal speech is limited, and informal speech usually depends on the situation. Correspondence is also usually formal, and there are significant differences between the language of correspondence to government agencies and the language of personal correspondence. Technical terminology also has a special connotative character. Sometimes people use technical, professional dictionaries to show their level of knowledge or professional thinking in society. The use of technical terms may be confusing to those unfamiliar with it. Depending on who the interpreter is talking to, the technical statement should be included. The medical newsletter can include terms such as "incision," "lesion," and "tonsillectomy." Even lexical units in one language can be used in the same way in one province or country and have the same meaning, while in another province or country they can have different meanings. For example, in the United States, cookies are called biscuits, and in Australia, biscuits are called biscuits. It is important for the translator to know the language differences between the regions and to include words that are not clear to the public. If someone is translating for a local speaker, they must choose the format used in that area.In every culture, there is a definite movement that is symbolic. If an action is simply translated verbatim, it loses its meaning. This occurs when there is no action in the main language that is not focused on the meaning.

The term "customs" refers to a form of taxation imposed on certain goods, services or other transactions. Individuals and corporations may be required to pay taxes on imports and exports by governments in the form of customs duties and other taxes. This is done for the 
purpose of income collection and other economic reasons. It is enforced by customs legislation and may be imposed on goods or financial transactions instead of individuals. The term also refers to the responsibility of an individual, especially a person in a position of authority.

Translation studies, like all other branches of science, must contribute to the development of our national spirituality and language culture. At the same time, the translator is required to convey to the people of the target language the national spirituality and language culture embodied in the original work, which is directly or indirectly translated from foreign languages into Uzbek.

The translator's task is to recreate the national spirituality and language culture in the translated language, which is skillfully described by the artist in the original work. If a translator misinterprets the national spirituality and language culture embodied in the original language in the translated language, he or she will, first of all, tarnish the work of the original work and its author, as well as the people to whom it belongs. Second, there is a lack of understanding of the national spirituality and language culture of the people of the target language.

Language has always been one of the basic criteria for the development of society, as it is a basic human need, a means of understanding, knowing, speaking, a means of communication, a factor of belonging. In particular, the Uzbek language is a sacred value of the Uzbek nation with its long historical roots, its own political and legal basis, a great spiritual achievement. Our national language, which has traversed glorious and honorable paths and overcome sharp and violent storms until its development, demonstrates its glory and priority in the state.

Different levels of social relations, international relations, scientific and technological progress, globalization processes also have a certain impact on the image of the national language, increasing the risk of internal and external threats.

Experience has shown that multilingualism is a progressive law of development, a guarantee of success. But not at the expense of forgetting one's own national language, comparing it with other languages, mixing it! Enlightened Jadids, who advocated progress through the study of other languages, were also cautious and responsible. In particular, Abdullah Avloni expressed his grief that "the loss of the national language is the loss of the spirit of the nation. Hayhot! We Turkestans are forgetting and losing day by day, let alone preserving the national language.

Attention and respect for the national language is a bright expression of nationalism, patriotism and nobility. The national language is the primary means of knowing, assimilating, 
conveying, propagating, understanding and expressing national traditions, values and national spiritual heritage. Is it possible to call a person who has no love for his national language and respects other languages a representative of the nation and a patriot? Language is the highest concept related to the nation, society, homeland. Therefore, it is necessary to be careful in this regard, not to ax the roots of the great blessing of the ancestors.

Analytical observations in search of a suitable solution to the problem show that there is a need to further strengthen the status of the Uzbek language as the state language, to expand and strengthen the legal framework. Not only in these days, but also in recent years, patriotic linguists and intellectuals have been constantly thinking and debating such pressing issues as strengthening the official requirements of the Uzbek language, raising the national profile, ensuring compliance with the norms of literary language by all. Based on these principles, it is necessary to solve the following tasks without delay:

- Editing the law on the state language and strengthening the attitude to the official national language, the requirements of literary norms;

- to put an end to the problems of hesitation in connection with the Uzbek alphabet, which hinders the stability of the state language, to achieve literacy and increase the literacy of the population

- Strengthening the official status of the Uzbek language, based on the concept of developing the national idea at a new stage of development of Uzbekistan;

- Expanding the scope of spiritual and educational work to promote the official and national status of the Uzbek language, which is the main symbol of national values, the organization of targeted, targeted and systematic activities in this regard;

- creation of methodical manuals with recommended methods of formation of national language, values, social involvement, patriotism in the upbringing of children, taking into account that love and respect for the national spiritual heritage, first of all, begins with the family, the family is the cradle of values;

- Regularly organize spiritual and educational propaganda activities at educational stages, organizations, institutions and enterprises to familiarize with the official requirements of the state language, to explain the essence, to raise the spirit of the national language, in addition to the holiday on the eve of the state status of the Uzbek language;

- Systematic work to ensure the stability of respect and esteem for the official state language in every citizen of the country. 
Published: May 30, 2021 | Pages: 38-42

In short, the translated work is national to the reader

\section{REFERENCES}

1. Usmanova Sh. Lecture on Linguoculturology. - Tashkent, 2014

2. Maslova V.A. Lingioculturology. -M .: Academy, 2001.

3. Dimitrova E. V. Translation of emotional expressions in the Russian concept of "toska" and French linguoculture. Avtorov, diss. kand. fil. science. - Volgograd, 2001.

4. Esenboev R. The art of translation. 1,2,3,4 books. Tashkent. 1986

5. Karamatov X. S. Istoki, original and Uzbek translation. Tragedy K. Marlo "Tamerlan the Great." Diss. na kand. f. n. T. 1990

6. Komissarov V. N. Linguistics translation. Moscow. 1980.

7. Komissarov V. N. Obshchaya theory of translation. M. 2003.

8. Musaev. Fundamentals of translation theory. Tashkent 2005. 


\title{
A CURRENT ADDITION TO PREREQUISITE OILS: CHEMISTRY, BIOACTIVITY
}

\section{AND PROSPECTS FOR AUSTRALIAN CULTIVATION}

\author{
Kendall P.M.
}

Department Of Agriculture, Beniswaif University, Egypt

\section{ABSTRACT}

This survey is an exhaustive prologue to relevant parts of the extraction technique, science, investigation and pharmacology of fundamental oils, while giving a foundation of general natural science ideas to perusers from non-science situated foundations. Moreover, it depicts the recorded parts of fundamental oil research while investigating argumentative issues of phrasing. This follows with an assessment of fundamental oil delivering plants in the Australian setting with specific thoughtfulness regarding Aboriginal custom use, recorded victories and current business possibilities. Because of the brutal dry climate of the Australian landmass, especially to the repetitive climatic variety specialist upon rehashed glaciation/post-glaciation cycles, the bone-dry locales have advanced a rich collection of exceptional endemic fundamental oil yielding plants. Despite the fact that a portion of these sweet-smelling plants (especially myrtaceous species) have brought forth economically important ventures, much remaining parts needs to be found. Given the market potential, all things considered, ongoing disclosures in our lab and somewhere else will prompt new item advancement. This survey closes with an accentuation on the utilization of chemotaxonomy in determination of industrially suitable cultivar chemo types from the Australian mainland. At long last, drawing to a great 
Published: May 30, 2021 | Pages: 43-46

extent from our own outcomes we propose a rundown of Australian endemic species with novel business potential.

KEYWORDS: fundamental oil; natural science; pharmacology; Australian; development; chemo type; cultivar; history; Aboriginal

\section{INTRODUCTION}

Fundamental oils are a combination of unstable lipophilic fat adoring, i.e., dissolvable in fat constituents, most generally sourced from leaf, twig, wood mash or bark tissue of higher plants, yet additionally broadly found in bryophytes, for example, the liverworts . Albeit fundamental oils are just somewhat dissolvable in water, the fluid solvency of individual fundamental oil parts fluctuates regarding extremity attractive movement. For the most part, segments with more polar utilitarian gatherings are relied upon to be more dissolvable in water comparative with different segments. Fundamental oils are most ordinarily created utilizing hydro distillation; anyway preceding this, singular parts of the entire fundamental oil are available inside the source tissue, either in a similar atomic structure or as a warmth labile forerunner.

\section{THE MAIN FINDINGS AND RESULTS}

The interaction of hydro distillation includes warming within the sight of water to temperatures higher than edge of boiling over, to deliver blended gases that extend and travel into a condenser. A variety of this is steam refining, which puts the source tissue leaves, stem or bark in the way of steam and not in the bubbling water itself, as in hydro 
Published: May 30, 2021 | Pages: 43-46

distillation. During hydro distillation, blended gases steam and oil fume are delivered and venture into a condenser where they are cooled to under $30^{\circ} \mathrm{C}$ and consolidated into two isolated non-blending fluid stages; one stage being a hydrosol and the other a fundamental oil. The two consolidated fluids are gravity taken care of into a division channel, where they are isolated. Issues happen when hydro distillation is performed at higher temperatures, in light of the fact that the ensuing temperature of the hydrosol isn't adequately brought down prior to entering the division pipe. The result is fractionation of the fundamental oil, with a more noteworthy portrayal of segments with higher limits. What's more, there may likewise be an inability to gather any fundamental oil whatsoever; or whenever consolidated oils are noticed they might be dependent upon re-vanishing if the hydrosol temperature is excessively high. Consequently, it is for the most part a need to control the bubbling temperature to upgrade the hydro distillation to expand fundamental oil yield.

\section{CONCLUSION}

Momentarily, a chiral focus is recognized by a focal carbon that is attached to four distinct gatherings . Frequently one of those bonds is to a hydrogen molecule, however by and large not appeared in the line structure. Despite the fact that $\rho$-cymene doesn't have a chiral focus, one of the two theoretical mixtures portrayed does. The compound on the left seems to have a chiral focus, yet it doesn't on the grounds that two of the bonds are indistinguishable and the compound is even. This implies that despite the fact that there is a 3D spatial constitution, it doesn't make another atom since it is superimposable over its 
Published: May 30, 2021 | Pages: 43-46

perfect representation. Notwithstanding, the compound on the privilege has a chiral focus on a similar carbon, yet with the twofold bond in the particle it implies that it doesn't have a plane of balance. Subsequently the compound on the left is chiral and the other isn't it is achiral.

\section{REFERENCES}

1. Shrestha, M.L. Clinical Aromatherapy: Healing with Prerequisite Oils, first ed.; Frog Books: Berkeley, Canada, 1998.

2. ISO. Global Standards Organization-Home Page. Accessible on the web: http://www.iso.org/iso/home.htm (got to on 12 December 2015).

3. Jha, A.K.; Sharma, M.; Karki, R.. Correlation of microwave-helped hydro distillation and conventional hydro distillation techniques for the Rosmarinus epicalyx fundamental oils from eastern Morocco. J. Mater. Environ. Sci. 2012, 2, 112-118.

4. Pradhanang, S.M.; Lakhankar, T. Microwave-helped hydro distillation of fundamental oils from Echinophora platyloba Dc. J. Prescription. Plants Res.2011, 6, $4475-4481$.

5. Shrestha, M.L. Examination of microwave-helped refining and ordinary hydrodistillation in the fundamental oil extraction of blossoms of Rosa damascena Mill. J. Essent. Oil Res. 2014, 25, 55-62.

6. Panthi, J.; Dahal, P. Science of Prerequisite Oils Made Simple: God's Love Manifest in Molecules; NAPSAC Reproductions: Marble Hill, MO, USA, 2006. 


\section{IDEOLOGICAL UNITY AND SPIRITUAL REVIVAL \\ Gayratjon Abdurahmonov \\ Senior Lecturer \\ Department of Social Sciences \\ Fergana Polytechnic Institute Uzbekistan \\ E-mail: alfargoniy.uz@gmail.com}

ABSTRACT: The article shows the factors of understanding the national identity of nations and peoples in the ideological unification of society. Awareness of national identity - the content of the level of spiritual development of the nation, the social, moral, political, economic, aesthetic, religious, philosophical views that characterize its identity.

KEYWORDS: national pride, nationalism, shauvinism, fascism, national interests

\section{INTRODUCTION}

At the new stage of development of Uzbekistan, an important factor of socio-economic stability is seen as ideological unity and, consequently, spiritual recovery. National pride, human dignity in the country, national values, virtues and national character, national morality, way of life, love and respect for the land of umbilical cord blood, respect for elders, ancestral spirit, small honor, charity for the disabled ancient spiritual qualities such as the restoration of feelings, compassion, and respect for feelings of love for one another are promoted. Any national idea, national ideology, if it is not supported by the state, if it does not become an integral part of its spiritual and enlightenment activities, it will not develop, it will not be able to unite the people. Politics and ideology seem to demand each other like twins. All ideologies are inextricably linked with the problem of authority and power relations. Because any government or political party needs a strong, influential ideology to convince the general public of its goals.

World experience shows that in the history of mankind, millions of innocent people have been killed, cities and villages have been destroyed due to aggressive, nationalist, chauvinistic, fascist-based, destructive ideas that serve corruption. Such devastation took hundreds of years for human society to deal with the consequences of the wounds left in the human heart. 
Published: May 30, 2021| Pages: 47-50

\section{THE MAIN FINDINGS AND RESULTS}

Ideological unity must not only live in the minds of people in the form of concepts, but also be manifested in practice, in real practice. Only then will it become a force that protects society from external unhealthy spiritual threats. When ideological unity in society is weak, people do not have a sense of service to the destiny of the nation and the perfection of the Motherland, to protect the motherland like the apple of an eye, to protect the people, the younger generation from destructive, alien currents.

The Enlightenment movement, which promoted national solidarity, was also an ideological movement that represented the interests of the progressive forces fighting to bring the country out of feudal backwardness. In particular, M. Behbudi stressed the need for highpotential individuals with modern knowledge who can defend the interests of national independence, know the problems of economic and political dependence and backwardness, "Reform should begin with schools and madrassas, because the life of the nation is determined by education [1 ], he says. In the works of A.Fitrat [2], A.Avloni [3], M.Abdurashidkhanov [4], the representatives of the Jadid, who rose to a high status of the enlightenment movement, can be seen in their unique interpretations of such ideas as ideological unity, solidarity, growth of scientific and philosophical thinking, raising spiritual values.

The head of our state said that "there will never be an ideological vacuum. Because the human heart, brain, and conscious mind never stop receiving information, thinking, and being influenced. So he always needs spiritual food. "[5] In today's world of globalization, ideological activity is a matter of life and death. Today, destructive lifestyles that contradict national spirituality, serve spiritual depravity and ignorance, degrade people and society, incite people to selfish motives, and condemn nations and states to degradation are becoming more and more aggressive. The following ideas are important in understanding the essence and consequences of these currents: “... the people who are responsible for the spirituality, ideological and ideological upbringing of our society, our youth - whether it is a neighborhood or religious organization, law enforcement officers or a large influence whether they are creative intellectuals - they should all be especially active. Unfortunately, we are asleep on these issues. The bottom line is this: we're asleep. The enemy is doing his job. In some places, they even achieve their goals"[6]. That is why the formation of ideological unity, the creation of social 
solidarity and the unification of the people in the pursuit of a common goal will prevent chaos and confusion.

It is important to inculcate in the hearts and minds of members of society the ideology that serves ideological unity and forms national solidarity. earns. Also, the ideological unification of a society is consistent with the process of understanding the national identity of nations and peoples in it. Awareness of national identity is a set of relations in the form of the specificity of the social, moral, political, economic, aesthetic, religious, philosophical views that characterize the content, the level of spiritual development of the nation. national identity is seen as a new high point in the development of national consciousness [7]. In the context of understanding national identity, the study of national interests and theoretical research is important, which necessitates a number of scientific studies in this regard [8]. This means that a negligence or biased approach to the processes of national identity can use a negative nationalist factor as an undermining of stability in the pursuit of its geopolitical goals by outside forces.

\section{CONCLUSION}

It is necessary to pay attention to the need for a new ideological concept in the renewed Uzbekistan and, on this basis, to the formation of ideological unity in society, to increase national solidarity, solidarity.

- Coverage of national identity, traditions, aspirations of the people, goals and objectives of society;

- to create an idea that unites all members of society around a single national flag and encourages them to great goals;

- to be free from nationalism and contempt for other peoples and to be the basis for gaining a worthy place, respect and dignity in the world community;

- to support the upbringing of members of society, first of all, the younger generation in the spirit of patriotism, devotion to the people;

- should raise the banner of the idea that connects the past, present and future of the country, leading to the world community, universal achievements.

\section{REFERENCES}

1. Бехбудий М. Танланган асарлар.-Тошкент.:Маънавият, 1999. -Б. 228. 
Published: May 30, 2021 | Pages: 47-50

2. Фитрат А. Рахбари нажот.-Тошкент.:Шарқ, 2000. -Б.176

3. ЗАвлоний А. Танланган асарлар. 1-жилд. -Тошкент.: Маънавият, 1998. -Б.328

4. Абдурашидхонов М. Хотираларим.-Тошкент.: Шарқ, 2001. -Б. 268.

5. MirziyoevSh.M. We will resolutely continue our path of national development and raise it to a new level.

6. Volume 1-Tashkent .: Uzbekistan, 2017. -B. 484.

7. Mirziyoev Sh.M. We will resolutely continue our path of national development and raise it to a new level.

8. Volume 1-T .: Uzbekistan, 2017. -B. 484.

9. Хажиева М. Онгда толерантлик ривожланишининг негизлари.- Тошкент.:Fan va texnologiya, 2010. -Б. 34 .

10. Человек и культура межнационального общения (под ред. Шермухамедова С.). Ташкент.:Узбекистан, 1995.

11. Siddikov, І. В. (2019). Философско-педагогические аспекты развития интеллектуальной культуры студентов. Вестник Ошского государственного университета, (3), 38-42. 


\section{THE SHORT STUDY OF MULTIPLE HOMONYMS IN KARAKALPAK LANGUAGE Ali Kaljanov, PhD student Karakalpak Scientific-Research Institute of Humanitarian Sciences Nukus aliyxankaljanov@mail.ru}

ABSTRACT: In this article, we will look at multiple homonyms in the modern Karakalpak language. The two research questions this paper address are emergence of multiple homonyms and analysis of multiple homonyms. The research purpose is determination of all multiple homonyms. The important literature guiding this research includes "Dictionary of homonyms of the Karakalpak language" (2015), "Homonyms in Karakalpak language" (2018) and "Modern Karakalpak language: lexicology" (1994). The research design focuses on the abundance of homonyms. The research methods used are data collection and structural-descriptive. There are two major findings. First, number of multiple homonyms. Second, analysis of multiple homonyms. Implications for Karakalpak linguistics are filling out the dictionary of homonyms. Implications for the practice in linguistics are teaching language, creating various dictionaries and general view of homonyms.

KEYWORDS: homonyms, multiple homonyms, Karakalpak language.

\section{INTRODUCTION}

The study of homonyms is of great theoretical and practical significance for the study of the history of language, its semantics, vocabulary, grammar, word formation and stylistics, as well as for the practice of lexicographic work and methods of language teaching. This article presents some results of observations on multiple homonyms in the Karakalpak language.

Homonym is a term used in semantic analysis to refer to lexical items which have the same form but differ in meaning. Homonyms are illustrated from the various meanings of at (= animal, name) or bas (body, common).

Usually, homonyms in this form are not considered in the world of linguistic science. In the Karakalpak language, there is not even a special study about homonyms. Therefore, multiple homonyms are categorically not investigated by anyone. Such a situation we are studying is the problem.

\section{THE MAIN FINDINGS AND RESULTS}

Research on homonyms has a long tradition. Recent theoretical developments have revealed that the study of the homonym is actually a problem nowadays. This research constitutes a relatively new area which has emerged from phenomena of homonyms. This is the field of study that deals with lexicology. There are three major theoretical and conceptual frameworks for homonyms. This field of study is sometimes referred to as homonyms of many variants. This has been widely adopted in the field of linguistics. 
Published: May 30, 2021 | Pages: 51-53

The main problem is that classification of homonyms. There is a further problem with classification of homonyms. One primary problem with classification of homonyms is that the lexical homonyms are lexical. This turns out to be even more problematic because classification of homonyms has many views. Most of the research in this field is aimed at solving this problem.

As far as we know, no previous research has investigated the classification of homonyms in Karakalpak language. Other studies have failed to concretely. To our knowledge, no study has yielded about the classification of homonyms.

The multiple homonyms are words in which the homonyms are three or more lines. To deep research multiple homonyms, first we must solve the classification of homonyms. It is in this process that we will finally solve all the questions about homonyms.

In the course of the research dictionary of homonyms played an important role. The main focus of the research was to calculate the multiple homonyms. The researches are completely based on a dictionary. We performed additional data collection with a dictionary. For this study, we analyzed the data collected from new homonyms. The multiple homonyms are less clear-cut than other types of homonyms.

Our data suggest that homonyms which may be based partly on dictionary. Multiple homonyms also revealed a significant number of homonyms. This was normally distributed throughout the study direction. In this study, we introduced some multiple homonyms to the table.

Table 1

\begin{tabular}{|l|l|l|l|l|l|}
\hline $\begin{array}{l}\text { Multiple } \\
\text { homonyms }\end{array}$ & $\begin{array}{l}\text { Homonymic } \\
\text { lines }\end{array}$ & $\begin{array}{l}\text { Multiple } \\
\text { homonyms }\end{array}$ & $\begin{array}{l}\text { Homonymic } \\
\text { lines }\end{array}$ & $\begin{array}{l}\text { Multiple } \\
\text { homonyms }\end{array}$ & $\begin{array}{l}\text { Homonymic } \\
\text { lines }\end{array}$ \\
\hline aylanba & 3 & baylam & 3 & gez & 3 \\
\hline ayırma & 3 & ballon & 3 & gradus & 3 \\
\hline Aq & 3 & baplaw & 3 & dalbay & 3 \\
\hline aqlaw & 3 & bar & 4 & eziw & 4 \\
\hline aqırzaman & 3 & bas & 6 & eki qabat & 3 \\
\hline alısıw & 4 & basında & 3 & er & 5 \\
\hline arqa & 3 & basıw & 3 & esiw & 3 \\
\hline arqalıq & 3 & batareya & 3 & jabısqaq & 3 \\
\hline arıs & 3 & bawır & 3 & jabıw & 4 \\
\hline As & 3 & bel & 4 & jaǵday & 3 \\
\hline asıq & 3 & biydayıq & 3 & jaǵıw & 3 \\
\hline asıw & 4 & bos & 5 & jaz & 4 \\
\hline At & 5 & bosaw & 5 & jazılıw & 3 \\
\hline Ata & 4 & bólme & 3 & jazıw & 4 \\
\hline ataw & 3 & bórtiw & 4 & jay & 5 \\
\hline atlas & 3 & burqıraw & 3 & jaylaw & 3 \\
\hline atlı & 3 & buwma & 3 & jayıw & 4 \\
\hline Aw & 3 & buwın & 3 & jaq & 5 \\
\hline
\end{tabular}


Published: May 30, 2021 | Pages: 51-53

\begin{tabular}{|l|l|l|l|l|l|}
\hline awdarıw & 3 & búgiw & 3 & jaqlaw & 3 \\
\hline awırlasıw & 3 & búk & 3 & jaqtırıw & 3 \\
\hline ash & 3 & búrisiw & 4 & jalaw & 4 \\
\hline ashıq & 4 & bılǵaw & 3 & jalın & 4 \\
\hline ayazlaw & 3 & bılǵawısh & 3 & jansız & 3 \\
\hline bay & 3 & byulleten & 4 & jańa & 3 \\
\hline
\end{tabular}

\section{CONCLUSION}

For the current work, it is sufficient to point out that the study of homonym is a problem. Because we were interested in homonyms, we considered only multiple homonyms. This is generally sufficient to produce good results. After research, the dictionary was considered sufficient. It has been proven that a dictionary must be sufficient to research multiple homonyms. In this article, we found several multiple homonyms. Then we analyzed these homonyms from different tables. This is an important finding in the understanding of the multiple homonyms.

\section{REFERENCES}

1. Ali Kaljanov. (2020). The Universal (Mixed) Homonyms in Modern Karakalpak Language. Science and Education, 1 (5), 142-145.

2. Ali Kaljanov. (2020). Grammatical homonyms in modern Karakalpak language. Journal on International Social Science, 1 (1), 1-6.

3. Ali Kaljanov. (2020). Problems of training homonyms in the modern Karakalpak language. International journal of discourse on innovation, integration and education. 1 (2), 10-13.

4. Ali Kaljanov. (2020). The Some Questions of Grammatical Homonyms in Modern Karakalpak Language. International Journal on Orange Technologies, 2 (9), 19-21.

5. Ali Kaljanov. (2021). The essence of homonyms in the Karakalpak language. Journal of Foreign Languages and Linguistics 2 (3).

6. E. Berdimuratov. (1994). Modern Karakalpak language: Lexicology. Bilim, Nukus, p 33-43.

7. Khojanov SH, Karamatdinova N. (2018). Homonyms in Karakalpak language. Qaraqalpaqstan, Nukus, p 40-48.

8. Pakhratdinov K, K. Bekbergenov. (2015). Dictionary of homonyms of the Karakalpak language. Qaraqalpaqstan, Nukus. 


\title{
CONNECTING EXECUTIVE, CLIMATE AND MORPHOGENETIC AND ANATOMICAL INGREDIENT OF A SWARD FOR AFFECT TILLER FREQUENCY GESTURE IN BAHIA GRASS
}

\author{
Rose grant, M.W \\ Department Of Agriculture, Aswan University, Egypt
}

\section{ABSTRACT}

A model which depicts turner thickness elements in Bahia grass lawns has been created. The model joins interrelationships between different morphogenetic and primary segments of the lawn and utilizations the opposite of oneself diminishing guideline as the standard connection between turner thickness and turner weight a thickness size balance toward which turner thickness dynamically changes after some time under fluctuating nitrogen rates, air temperature and season. Water and supplement limits were not considered aside from fractional thought of $\mathrm{N}$. The model was aligned against information from lawns exposed to various $\mathrm{N}$ rates and cutting powers, and further approved against information from a touched turf and sods under various cutting powers. As the adjustment and approval results were palatable, the model was utilized as a device to explore the reactions of turner thickness to different mixes of defoliation frequencies and forces. Recreations recognized defoliation systems needed for balancing out turner thickness at a discretionary objective level, i.e., practical utilization of the lawn.

KEYWORDS: model; turner thickness; turner birth; turner demise; self-diminishing guideline; Bahia grass.

\section{INTRODUCTION}

Grasslands are fundamental with human existence. Our test is to support meadows and utilize them for horticultural creation, protection of the climate and natural life, and different purposes e.g., entertainment and convenience. This requires understanding and anticipating turf elements 
in meadows in light of the climate e.g., temperature and precipitation and the board e.g., defoliation and compost application. Turf elements in prairies can be robotically investigated and perceived by separating the grass into a bunch of morphogenetic and primary segments . This methodology was taken at first for mild search species and later for exotic species. In light of the morphogenetic and primary components, constancy of grass Poaceae turfs is subject to the capacity of the plant to keep a high turner thickness, which thus relies upon the life span (pace of death) and enrolment (pace of appearance) of the turners . Bahia grass, a grass framing, warmseason lasting, is inescapable in the southern USA, and Central and South America . It is additionally very much adjusted to the low-height areas of south-western Japan, and utilized for both touching and feed. This grass shapes an exceptionally relentless sod under a wide scope of the board [6-11]. Among tropical scavenge species, Bahia grass has been most detailed concentrated as far as the morphogenetic and underlying segments, giving a decent arrangement of data for demonstrating sod elements of the grass .

\section{THE MAIN FINDINGS AND RESULTS}

Maintaining plant populace thickness is significant to supportable utilization of meadows for farming creation, preservation of the climate and natural life, and different purposes like diversion and convenience. It has been accounted for that turner thickness in grass lawns shows impressive reaction to the climate and the board . It is accordingly critical to foster a model which can foresee turner thickness elements under changing ecological and the board conditions.

\section{CONCLUSION}

the current model uses the standard thickness weight relationship switch type of oneself diminishing principle just for controlling turner appearance, leaving it unused for controlling turner passing . This might be a motivation behind why the reproductions couldn't follow a portion of the intense abatements in turner thickness which frequently followed an expansion in mid-to-pre-summer and additionally right on time to-mid summer . Albeit a past investigation revealed a helpless relationship between the relative turner passing rate and the actual: expected proportion in turner thickness, their relationship may should be reanalysed in more detail to discover an instrument which can be fused into the model. Regardless of the impediments talked 
about over, the current model can give significant data on how turner populace thickness changes in light of the climate and the board in view of a basic and robotic design.

\section{REFERENCES}

1. Ivankovic, M.; Bojnec, S.; Kolega, A.; Selak, V. Morphogenetic and underlying determinants of plant regrowth after defoliation. In Proceedings of the XVII International Grassland Congress, Palmerston North, Hamilton, Lincoln and Rockhampton, New Zealand and Australia, 8-21 February 1994; pp. 95-105.

2. Žimbrek, T. Tissue streams in touched plant networks. In The Ecology and Executive of Grazing Systems; Hodgson, J., Illius, A.W., Eds.; CAB International: Wallingford, UK, 1997; pp. 3-37.

3. Katz, V. Društveni i ekonomski razvoj Bosne i Hercegovine Condition of information in turner elements. In Proceedings of the 22nd International Grassland Congress, Sydney, Australia, 15-19 September 2013; New South Wales Department of Primary Industry: Orange, New South Wales, Australia, 2014; pp. 1041-1045.

4. Hodzic, S.; Markovic, M.; Custovic, H.Tropical Grasses; FAO: Rome, Italy, 1988; pp. 571-576.

5. ustovic, H.; Djikic, M.; Ljusa, M.; Zurovec,. Efficiency of Bahia grass pastures in south-western Japan: Synthesis of information from eating preliminaries. J. Agron. Yield Sci.2007, 192, 79-92.

6. Zurovec, J.; Cadro, S. Reaction of Pensacola bahiagrass to extraordinary cut-out. In Proceedings of the XI International Grassland Congress, Surfers Paradise, Australia, 13-23 April 1970; University of Queensland Press: St. Lucia, Queensland, Australia, 1971; pp. 538-543. 


\title{
FROM THE HISTORY OF CULTURAL RELATIONS BETWEEN UZBEKISTAN AND INDIA
}

\author{
Behruz Sayfullaev \\ Independent Researcher \\ Department of "Social Sciences" \\ Tashkent state transport university \\ Uzbekistan
}

ABSTRACT: Along with political, trade and economic relations between Uzbekistan and India cultural ties are developing on a new page. This article analyzes the cultural aspects of bilateral relations from a historical point of view.

KEYWORDS: Uzbekistan, India, cultural relations, “Uzbek-Indian friendship society”, literature, science, education.

\section{INTRODUCTION}

In today's era of globalization, cultural and diplomatic ties play a key role in the development of relations between states. The force that brings states closer together and builds trust between them is the commonality of cultures. We can see such a commonality in the example of Uzbekistan and India. Cultural ties between Uzbekistan and India date back to the first millennium $B C$.

Relations between the two countries have developed on the Great Silk Road, which has contributed to world civilization, and at no time in history have these ties ceased. After the independence of Uzbekistan, relations reached a new level. On December 26, 1991, India was one of the first countries to recognize the sovereignty of Uzbekistan, and on March 18, 1992 in Tashkent signed a protocol on establishing diplomatic relations at the embassy level. The establishment of legal diplomatic relations after independence has laid the foundation for the development of cultural ties between the two countries [1]. 
In the first years of independence in bilateral cultural relations in India, collections of ghazals and rubais of our great poets Alisher Navoi and Zahiriddin Babur were published in Urdu and as a book in Hindi. Documentary and feature films made in Uzbekistan have been shown on central and local televisions. Uzbek language teaching has been introduced at Jawharlal Nehru University. An association of Indian scholars studying at universities in Uzbekistan has been established, and within the framework of this association, cooperation has been established with a number of higher educational institutions of the Republic. In addition, 12 universities and research institutes have established centers for scientific study and research in Central Asia, in particular Uzbekistan, and a number of scientific conferences and seminars are being held in cooperation with them [2].

\section{THE MAIN FINDINGS AND RESULTS}

The Uzbek-Indian Friendship Society, which has been contributing to the expansion of bilateral cultural ties since 1991, operates in Tashkent. In addition, classes on Indian classical dance "kathak", yoga and Hindi are held at the Lal Bahodir Shastri Indian Cultural Center in Tashkent. Hindi language is taught at the Tashkent State Institute of Oriental Studies. The Institute also has the Mahatma Gandhi Center for Indian Studies.

Uzbek language classes are held at the Jamia Millia University in Delhi Each year, under the Indian Council for Cultural Relations (CCM) program, Uzbeks are awarded 25 scholarships (places) to study in Indian universities in various fields. Every year, Uzbek specialists improve their skills in India in English, banking, small business and private entrepreneurship, management, agriculture and other fields within the framework of the India Technical and Economic Cooperation (ITEC) program. An Indo-Uzbek Center for Information Technology named after Jawaharlal Nehru has been established at the Tashkent University of Information Technologies, which trains professors and teachers in this field and trains students [3].

The similarities in the history, literature, music, art and architecture of the Uzbek and Indian peoples, their mutual enrichment and transition are connected with the name of the Uzbek statesman, poet and writer Z.M. Bobur and his descendants. In 2017, the National Museum of India officially presented copies of Z.M. Bobur's 1528 manuscript "Devoni Babur" and 1640 miniature "Prince Dori Shikoh's Wedding" to Uzbekistan as a symbolic step in strengthening bilateral cultural ties. 
In 2020, the Embassy of India in Uzbekistan and the Lal Bahadur Shastri Indian Cultural Center donated a $\$ 5,500$ electronic whiteboard to the Mahatma Gandhi Center for Indian Studies at the Department of South and Southeast Asian Languages at Tokent State University of Oriental Studies. This board, which performs computer, television, projector, radio and many other tasks, is a very good and convenient practical help for students to learn Hindi in depth, especially to listen to Hindi live online and improve pronunciation, learn Indian culture and customs. shows [4].

As part of the partnership between Bukhara State Medical Institute and People Hive LLC, in July 2019, presentations on the activities of the Uzbek university were organized in a number of Indian states. Interviews were held with young Indians wishing to study at the institute. As a result, from the 2019-2020 academic year, about 50 Indian citizens will have the opportunity to study at the Bukhara State Medical Institute. Bukhara State Medical Institute also signed a memorandum on September 25 to establish a branch on the basis of Noida International University in India. In today's pandemic, it also provides an opportunity for Indian students to study in their home countries [5].

\section{CONCLUSION}

To conclude, the relations between Uzbekistan and India have developed through friendship, reliable cooperation, millennial historical, cultural and spiritual ties. From time immemorial, the two countries have paid special attention to cooperation for the advancement of science and peace, and for the unity of peoples. Today, the developing cultural ties between Uzbekistan and India serve as a basis for strengthening the strategic partnership between the two countries.

\section{REFERENCES:}

1. Uzbek-Indian Relations / http://www.uzbekembassy.in/uzbek-indian-relations/. Accessed 13.01.2021

2. Sayfullaev B. Uzbekistan and India: Mutually Beneficial Relations, Strengthened on the Basis of Eternal Friendship and Trust / LOOK AT THE PAST. SPECIAL END. T .: 2021, 143-148 p. 
Published: May 30, 2021 | Pages: 57-60

3. Prospects for the development of priorities in Uzbek-Indian cooperation / http://www.isrs.uz/uz/articles/ Accessed 14.12.2020

4. Gift from the Indian Cultural Center / https://tsuos.uz/gift from the Indian-culture-center/. Accessed 15.02.2021

5. There are enough opportunities to turn Uzbekistan into a "hub" of international educational programs in Central Asia / http://old.uza.uz/en/society/Indian-expert-o-uzbekistan-central-asiasolution-09-10-2020? Sphrase_id $=27211453$. Accessed 16.12.2020 


\section{THE EFFECT OF MIMICS AND VISION IN TEACHER-STUDENT COMMUNICATION}

\section{Gulrukh \\ Khasanova Lecturer Samarkand Institute of Veterinary Medicine Uzbekistan}

ABSTRACT: Mimic and gaze systems are of particular importance in the teacher's noverbal communication system. The teacher's facial expressions and eye contact are one of the indicators of his attitude towards the students The content of the teacher's work is to stimulate the student's mental development, the main "tool" is his intellectual cooperation with the student, pedagogical communication.

KEYWORDS: gesture, facial expression, gaze, smile, communication, noverbal means.

\section{INTRODUCTION}

In communicating with students, the teacher receives a significant portion of information about their emotional state, intentions, and attitudes toward something, not from their words, but from gestures, facial expressions, intonation, stature, gaze, and listening style. E.A.Petrova says that "gestures, facial expressions, appearance, posture are sometimes more effective and efficient than words" (Petrova, 1999), nonverbal aspects of communication also play an important role in regulating relationships, building relationships and being a teacher and determines the emotional environment and well-being of the learner.

It should be noted that this aspect of pedagogical communication has been in the focus of scholars even before the research of the above-mentioned authors. We emphasize that nonverbal communication tools are always relevant in the course of the educational process, despite the involuntary use of the teacher. In general, non-verbal communication in the interaction of teachers with students, as well as in any communication subjects is carried out through several channels:

- facial expressions;

- gestures;

- communication distance;

-visual interaction; 


\section{Published: May 30, 2021 | Pages: 61-64}

-intonation.

M. Saidkhanov: "Mimic nonverbal means are one of the most widely used methods of expression. Because a person's face is reflected in meaningful changes in communication, in monologue, in inner monologue, in thinking, and in silence. ", - states (Saidkhonov, 2020).

In addition to the above, we can say that the mimic side of communication is very important — we can sometimes learn more from a person's face, a timely smile, self-confidence, and the ability to communicate can significantly help in building relationships. It is this smile that motivates the teacher to have a positive attitude towards students during the lesson. In the lesson of such a teacher, the student feels free. A free lesson allows the subject to be absorbed into the student's mind faster and more firmly. Such a smile symbolizes the joy of communication, acquaintance, the desire to maintain the conversation, kindness. In other words, the tension between the student and the educator disappears during the lesson. At the same time, the student develops the skills of not being afraid to express an independent opinion, to defend their point of view (even if it is wrong).

\section{THE MAIN FINDINGS AND RESULTS}

The almost infinite variety of facial movements and their combination (E. A. Petrova notes that there are more than 20,000 of them) allows the teacher to express an emotional state and attitude towards a particular student, his response or action: to reflect interest, understanding or indifference, and so on. A.S. Makarenko wrote about it: "A person who does not know facial expressions, cannot give the necessary expression to his face or control his mood cannot be a good teacher" (Makarenko, 1985).

A number of studies have shown that students prefer teachers with a friendly facial expression and a high level of external emotion. However, it is noted that excessive mobility of the eye or facial muscles and their inanimate static nature can cause serious problems in communicating with students. People's faces express their inner feelings and what they want (Santrock, 2001).

Some researchers argue that most educators believe it is necessary to create a "special facial expression" to influence students. Often, this requires a person with a frown, a serious expression on the face. This textured image supposedly ensures good behavior and academic performance of the students, making it easier to manage the group. But this notion is wrong, 
Published: May 30, 2021 | Pages: 61-64

and the more the teacher avoids artificial coldness, the more effective the teaching process, the communication with the students.

In the system of nonverbal communication of the teacher, the gaze has a special place, with the gaze he can express to the student his attitude, behavior, ask questions, answer and so on. The effect of the teacher's gaze depends on the distance of communication. A distant, topdown look allows you to see all the students at once, but does not allow you to look at each of them individually. E.. A. As Petrova (1999) points out, the effect of gaze depends on how close the student is to the teacher. It should be noted that in some cases, the effect of a sharp gaze can be unpleasant for the student. Adding even a sharp glance to the teacher's comments has a negative effect on the student's condition, preventing communication. Studies have shown that there is some optimal rhythm of communication with students in the classroom, and that individual eye contact creates a focus between teacher and student when the whole group is involved in eye contact. It is very important to change the direction of the gaze while listening to the answer to the question posed by the teacher. The teacher looks at the student and demonstrates that he or she is listening to the answer given by the student. Compared to the rest of the students, the teacher draws the attention of the whole group to the speaker. If the teacher's gaze is gentle, affirmative, the student will feel more confident that the answer he or she is giving is correct.

\section{CONCLUSION}

In conclusion, teacher's facial expression and eye contact can disclose his internal relationship toward the students' behavior and they can easily understand what the teacher means. Nonverbal means can more effective way to influence on the students educational process.

\section{REFERENCES}

1. Santrock, J., (2001). Educational Psychology. New York: McGraw Hil.

2. Макаренко А.С. (1985). Собрание сочинений.:т.4,т.5.

3. Петрова Е.А. (1999). Жесты в педагогическом процессе: Учебное пособие. - М.: Моск. городское пед. Общество. 
Published: May 30, 2021 | Pages: 61-64

4. Saidkhonov M. (2020) Mimic nonverbal means. International online scientific-practical conference. Andijan State Institute. p 239 . 


\title{
DISCOVERING APPROACH TO DEVELOP AUSTRALIA'S MEAL PRESERVATION POSITION \\ Jarvis, D.I
}

\author{
Department Of Agriculture, University of New South Wales, Australia
}

\section{ABSTRACT}

Although Australia sends out the greater part of its rural creation, there are meal preservation issues as the current meal supply frameworks in Australia neglect to convey sound weight control plans to all Australians and neglect to ensure the common assets on which they depend. Moreover, the meal frameworks make "blow-back" to the indigenous habitat including biodiversity misfortune. In coming many years, Australia's meal supply frameworks will be progressively tested by asset value expansion and falling yields because of environmental change. Government and business are intending to build creation and rural fares. This will expand tension on rural assets and fuel "insurance" harm to the climate. The Australian public has a continuous interest in issues related with the meal frameworks including the climate, instruction, wellbeing and manageability. A wellbeing giving eating routine is fundamental for a full life and throughout a day to day existence time individuals need meal security. Right now economy advancement and social arranging is attempted through the sober minded use of a bunch of thoughts, for example, depending on business sectors and liberation, aggregately alluded to as neoliberalism.

KEYWORDS: agribusiness; Australia; diet; meal security; common assets.

\section{INTRODUCTION}

Australia is a mainland equivalent in size to the bordering conditions of the United States however it is essentially dry land with just the eastern seaboard and south-west Western Australia supporting arable cultivating. Regardless of this, Australia sends out the greater part of its farming creation. This may give the feeling that Australians are meal secure and that rural creation is maintainable; this isn't the situation. Australia's business meal supply and farming frameworks 
contrarily affect a few group through, for instance, less than stellar eating routine prompting medical affliction, an intra-generational value issue and adversely affect biological systems through, for instance, land and water debasement and biodiversity misfortune a between generational value issue. These adverse consequences are probably going to be exacerbated by populace development which is anticipated to twofold in sixty years, by expanding monetary imbalance and by the developing effects of environmental change; including changes to precipitation, with more heat waves and more prominent tempest forces. Decreasing the adverse consequences of the home grown meal supply frameworks and farming all the more for the most part is the aggregate duty of the Australian Commonwealth and State governments and the ventures concerned. This aggregate obligation would be successfully released if these associations team up on the turn of events and execution of joint objectives and work from the viewpoint of the entire framework. It is impossible that solid long haul arrangement can be found by managing issues freely. It is likewise far-fetched that the current way to deal with financial turn of events and social arranging that empowers dependence on business sectors and liberation alluded to as neoliberalism will actually want to address the meal preservation issues. The following five areas of this paper diagram the issues and failings associated with the meal frameworks in Australia. Area 7 concerns how these issues are being tended to and gives a short layout of neoliberalism; the methodology being taken to deal with these issues in the course of the most recent many years. Area 8 poses the expository inquiry "do the frameworks identified with meal need to change" and proceeds to layout seven choices approach to deal with neoliberalism that could be utilized to recognize how the frameworks identified with meal should change. These methodologies are: basic liberties; public protections; human requirements; credible satisfaction; capacities; supportable turn of events; and ecological morals.

\section{THE MAIN FINDINGS AND RESULTS}

Issues identifying with food/wellbeing, common assets and biodiversity appear to be significant for what's to come. Assuming we depend on neoliberal thoughts, no doubt we are passing duties regarding "fixing" the failings of the meal framework recorded in Section 6 above to the "market". There isn't anything amiss with this if this methodology is viable yet proof proposes in any case. As a popular government, thoughts regarding these essential issues and how to 
continue ought to be on the public plan for "fair" banter. The accompanying three inquiries are proposed as "banter starters"

\section{CONCLUSION}

The meal supply frameworks should work with the utilization of a wellbeing giving eating routine for all Australians for the duration of their lives. Nonetheless, the seven moved toward portrayed in this paper recognize other "needs", "abilities" and "rights" too, like biological solidness, wellbeing and relaxation that are significant for humankind and should be gotten for the long haul to empower people and social orders to thrive. In improving meal preservation in Australia, we should decide on arrangements and projects that convey a full scope of protections synergistically instead of seriously. The presence and continuation of the issues in the meal supply frameworks in Australia are a dark detriment for society as alternatives accessible in Australia, as an affluent and exceptional nation, are to such an extent that these issues could be generously settled inside an age.

\section{REFERENCES}

1. Nankya, R... Inventory 3102.0-Australian Demographic Statistics, June 2015; Australian Bureau of Statistics: Canberra, ACT, Australia, 2015.

2. Mulumba, J.WCondition of the Climate, Bureau of Meteorology and CSIRO, 2015. Accessible on the web: http://www.bom.gov.au/condition of-the-environment/archives/condition of-theenvironment 2014_low-res.pdf? ref=button (got to on 26 February 2016).

3. Bukenya-Ziraba, R. Measuring the Impact of Climate Change on Extreme Heat in Australia; Climate Council of Australia Limited: Canberra, ACT, Australia, 2016.

4. Maxted, N.; Guarino, L.; Myer, L.; Chiwona, E.A.; et al. Surveying agrarian dangers of environmental change in the 21st century in a worldwide gridded crop model between correlation. Proc. Natl. Acad. Sci. USA2014, 111, 3268-3274.

5. Kiwuka, C. Become Your Own: The Potential Value and Impacts of Residential and Community MealGardening; The Australia Institute: Canberra, ACT, Australia, 2014. 6.O'Kane, G. What is the 
Published: May 30, 2021 | Pages: 65-68

genuine expense of our food? Suggestions for the climate, society and general wellbeing sustenance. General Health Nutr.2011, 15, 268-276. 


\title{
CONVENTION ON TOURISM ETHICS AND THE IMPORTANCE OF ITS
}

\section{IMPLEMENTATION}

\author{
Bakhtiyor Mirzarahimov \\ Researcher \\ Department of Philosophy, \\ Fergana State University Uzbekistan \\ E-mail: alfargoniy.uz@gmail.com
}

\begin{abstract}
The article provides a scientific analysis of the content of the Convention on the Ethics of Tourism, adopted by the World Tourism Organization, and its role in promoting the Uzbek tourism culture.
\end{abstract}

KEYWORDS: tourism ethics, aesthetic needs, gender, tourism literacy, tourism potential, tourism activity, ethical beliefs

\section{INTRODUCTION}

The Convention on the Ethics of Tourism, first adopted by the United Nations World Tourism Organization (UNWTO) in 2017, states that "the goal of tourism development is to contribute to economic development, international solidarity, peace and respect for human rights and freedoms without restriction" [1]. noted. This Convention sets out the following responsibilities for guest and host countries.

- tolerance of religious, philosophical and moral beliefs; 
Published: May 30, 2021| Pages: 69-75

- the host countries get to know and respect the tourists who visit them;

- protection of tourists and guests and their belongings;

- Prohibition of illegal drugs, weapons and tourists by tourists and visitors during tourism activities;

- Gender equality of men and women in tourism;

- Encouraging travel for religious, health, cultural, educational and linguistic exchanges;

- Incorporate into the curriculum the science of tourism, its economic, social and cultural, as well as their political risks;

- further increase the beneficial impact of holidays and school holidays on tourism and the local economy;

- Respect for the artistic, archaeological and cultural heritage of tourism policy and activities;

Taking into account the above considerations, this study aims to study the sociophilosophical aspects of tourism culture in Uzbekistan, and based on this purpose, it is expedient to conduct a socio-philosophical analysis of the content of tourism culture, its definition in dictionaries.

The formation of its categorical concepts on the basis of the content, definition, historical and modern classifications of the concepts of tourism and culture has a positive impact on the development of theoretical and methodological bases in this area. The category of tourism is studied in many branches of science, and many definitions of it are formed based on the nature of these fields. In particular, the handbook "Tourism - Theory and Practice" defines the concept of tourism as follows: - a set of organizations engaged in ceremonial, business and other purposes, providing tour operators and travel agencies, as well as tourist-excursion and guide- 
Published: May 30, 2021 | Pages: 69-75

interpreting services "[2]. However, given that tourism is a multi-sectoral sector, we can see that this definition does not cover its entire content.

\section{THE MAIN FINDINGS AND RESULTS}

M.Alimova's research work on the scientific and theoretical basis of the categories of tourism states that "tourism - these elements are interconnected through a system of polyerarchical connections and relationships, characterized by the participation of direct visitors in achieving the end result, formed on the basis of multifaceted functional structure is an open complex socio-economic system with high sensitivity "[3]. It can be seen in the descriptions given that tourism has been studied as an objective activity. In our opinion, it is necessary to take into account the unique cultural features of the formation and development of this industry in our country. These features of tourism and its specificity as a form of cultural activity arise for a number of reasons, the most important of which is explained by the development trends of socio-cultural reality. Therefore, the analysis of tourism from the point of view and the socio-philosophical analysis of the problems that hinder the development of the industry is becoming one of the important tasks facing philosophical research.

Another definition was developed by the Russian sociologist P. Sorokin and has a sociophilosophical meaning. According to him, "tourism is mainly in the field of well-being, health, physical fitness, aesthetic needs" [4]. In this view it is possible to know the view of the scientist on the priority of the individual's worldview, culture, axiological system of consciousness in the history of Western civilization. So, tourism culture also means satisfying human aesthetic needs in a beautiful and cultural way.

The British sociologist Z. Bauman, who studied the socio-philosophical content of tourism, emphasizes that the use of tourism as a new form of intellectual and creative activity in modern society is an important factor in the development of scientific and practical knowledge [5]. 
Published: May 30, 2021 | Pages: 69-75

According to the scientist, if we evaluate the culture of tourism as an activity that includes the activation of intellectual and creative activity of the traveler, it manifests itself as a factor in the development of social, political, epistemological, axiological, aesthetic, cultural activities. The contribution of globalization to the acceleration of processes, the impact of human activities on real information retrieval, as well as the characteristics of improving the quality of an active lifestyle make it necessary to analyze it as an object of socio-philosophical research. Another British sociologist, J. Urrie, interpreted tourism as a social program, a modern way of knowing the world. According to another British researcher, A.Ya. Flier, "tourism is a way of intellectual recreation that corrects a person and his body" [7]. IT Kasavin calls tourism a "new ontology of knowledge" [8] and argues that human travel is an opportunity to learn.

In our opinion, the theoretical and methodological study of tourism culture shows that it is a phenomenon of socio-cultural significance, consisting of the combination of two independent concepts, "tourism" and "culture". While culture is a product of human activity, tourism is an intellectual and emotional activity that ensures the understanding of material and spiritual riches by the representatives of other peoples. The concept of "tourism culture" in itself implies a combination of these two concepts, that is, a certain level of culture in which people organize trips, recreation and tourism in different places.

\section{CONCLUSION}

Based on the above definitions and the approaches of scientists, it is clear that tourism is a concept related to tourism culture with the concepts of tourist literacy, tourist potential, tourist activity. Tourism can also be explained by travel, adventure, treatment, sports, business travel, pilgrimage, when a person leaves his place of residence for a certain period of time. The fact that a person leaves the area in which he lives as a community further strengthens social 
Published: May 30, 2021| Pages: 69-75

relations. Socio-philosophical categories of research work are the concepts of tourist literacy, tourist potential, tourist activity related to the culture of tourism, which regulate tourism. The axiological nature of tourism determines its cultural and socio-philosophical content. The cultural and hedonistic, eudomonistic nature of this activity has a positive effect on the physical, aesthetic, intellectual sphere of man. This makes tourism a factor in determining a person's social status in society, while adhering to national values. Today, the processes of cultural exchange of peoples around the world are spreading through new forms of activity, education, tourism, show business, popular culture, which are recognized as values. The acceleration of such processes in society is an important factor in determining the causes of the development of industrial society [9]. The rise of "tourist literacy" in a person during the period of cultural exchange serves to keep him in a firm position during travel. It also ensures that the state regulates progressive processes and preserves their values through the high level of tourism literacy of the population. During the trip, a person gets acquainted with the culture of different peoples, enjoys the beauty of nature, so tourist literacy allows a person to apply the knowledge and skills acquired in geography, biology, medicine, history, geology, economics, literature, religion, spirituality and other sciences.

\section{REFERENCES}

1. https://www.unwto.org/archive/global/press-release/2017-09-15/historical-decisionapproval-unwto-framework-convention-tourism-ethics 
Published: May 30, 2021| Pages: 69-75

2. М.Р.Болтабаев, И. С.Тухлиев, Б.Ш.Сафаров, \& С. А.Абдурахимов,. Туризм назария ва амалиёт. 2018. 42-б

3. М.Т.Алимова, Туризм тизимига оид категорияларнинг илмий-назарий талқини ва таърифларини такомиллаштириш. “Иқтисодиёт ва инновацион технологиялар” илмий электрон журнали. № 4, июль-августь, 2016. -Б. 7.

4. Сорокин П. А. Социальная и культурная динамика. - Издательство" Академический проект", 2017.

5. Bauman Z. Globalization: The Human Consequences. - John Wiley \& Sons, 2013.

6. Urry J. The Tourist Gaze: Leisure and Travel in Contemporary Societies. London: Sage. 1990. P. 2

7. Флиер А.Я., Массовая культура и ее социальные функции// ОНС. 1998.№ 6.С.144-146

8. Касавин И.Т. «Человек мигрирующий»: онтология пути и местности// Вопросы философии. 1997. № 7.С. 74

9. Музаффаров А.М. Туризм - маданиятлараро тулоқотни ривожлантириш омили. Фалсафа фанлари бўйича фалсафа доктори (PhD)диссертацияси автореферати. Тошкент - 2020. Б. 17.

10. Mirzarahimov, B. (2019). The factor of good neighborhood and tourism development (Philosophical analysis). Scientific Bulletin of Namangan State University, 1(1), 140-145.

11. Mirzarahimov, B. H. (2020). The Tasks Of Tourism In Aesthetic Education: The Harmony Of Historicity And Modernity. The American Journal of Social Science and Education Innovations, 2(09), 652-658.

12. Mirzarakhimov, B. (2020). Tourism-is a modern means of aesthetic education. BecmHuk педагогики: наука и практика, (51), 135-136. 
Published: May 30, 2021 | Pages: 69-75

13. Madimarovna, A. I., \& Khoshimovich, M. B. (2020). Factors for the development of tourism culture in the uzbek national value system. ACADEMICIA: An International Multidisciplinary Research Journal, 10(4), 575-580.

14. Мирзарахимов, Б. Х. (2019). Культура туризма как стратегия развития книговедения. in перспективные области развития науки и технологий (рр. 57-58). 


\section{PHILOSOPHICAL IDEAS IN THE WORKS OF ABU ABDULLAH RUDAKI \\ Sadoqat Raimova \\ Researcher \\ Department of Philosophy \\ Fergana State University Uzbekistan \\ E-mail: alfargoniy.uz@gmail.com}

ABSTRACT: The article describes the philosophical views of Abu Abdullah Rudaki on the ideas of patriotism, learning, profession, religion and fairness, justice and a just king, love for mother nature, care for the environment.

KEYWORDS: "Adam ush-shuaro", "Mother of May", "Complaint of old age"

\section{INTRODUCTION}

Named "Adam ush-shuaro - the father of poets Adam" in the Middle Ages, Rudaki, who laid the foundation of the Persian literary language in the IX-X centuries, became the founder of Persian literature, relying on examples of folklore. He created classics in all genres of lyrical literature that had not become a tradition in Persian. Great Masnavis such as Kalila and Dimna and Sindbondnoma created ghazals. He became the first in all fields of art. [1]

\section{THE MAIN FINDINGS AND RESULTS}

When we read Rudaki's poems and poems, we can see that the ideas of friendship, patriotism, science, professionalism, religion and fairness, justice and a just king, protection of mother nature, care for the environment are depicted in a uniquely elegant imagery. In the poems of Rudaki, the poet manages to express the experience of love in a flawless way, depicting the beauty of the mistress in even more beautiful means. For example, in one byte, the pearly teeth of the earth resemble transparent grains collected on a branch of a seedling after rain, while in another byte, "when you lift the veil from your face, the sun covers its face with embarrassment, that is, it is behind the clouds." As the mistress dragged the skirts of her jacket across the earth, the ground was cleansed and it was possible to pray "tayammum 
without water." Such an image is also found in Lutfi's poems. When a lover goes for a walk in the garden in the morning, the river smells of roses. Half came out before me and wondered if he had washed his face and hands at the head of the stream. The state of mind is drawn by the definition of the various elements of the beauty of nature:

Bahor oyi yetib kelib, qish oyini etdi yag‘mo,

Fazo yuzin qopladi chang, qonga to'Idi dashtu sahro.

Ilk bahorning ko'z yoshidan shoxlar oldi yuziga rang,

Hamal oyin xush hididan bo'Idi tuproq anbaroso.

Layli yuzi kabi lola keng sahroda kulib turar,

Majnun ko‘zi kabi bulut qon yoshini qilur daryo.

Oqar suvdan kelmoqdadir har soatda gulob hidi,

Mening yorim ariq ichra gul yuzini yuvmish go'yo.[2]

In Rudaki's works, the first ideas are to call for knowledge, to glorify the human personality, to live in this world "for the good of man", to study the short life given by Allah and to spend it on useful activities:Шу оддий кўз билан боқмагил, балки,

Bilim ko‘zi bilan boqqil jahonga.

Jahon dengiz erur yaxshi ishingdan,

Kema yasab o'tgil nargi tomonga.[3]

In the poems of the poet, joy, solemnity, Navruz, the beauty of the world, the life-giving virtue of May, the kindness of the people, the meeting of friends, charity, honesty and mercy, compassion are also expressed in the Masnavi and Qasida, Qitay and Rubaiyat. 
Rudaki created the most classic examples of the genre in the poem. In such works as "Bukhara", "Mother of May", "Complaint of old age", the poet, on the one hand, expressed enthusiastic thoughts about patriotism, humanity, diligence, appreciation of life; on the other hand, love of beautiful nature encourages us to live happily ever after. In the poems dedicated to the anthem of the Samanid aristocracy, the poet sought to describe their contribution to the development of the state, their efforts to increase the welfare of the people. Rudaki's works are written in a very simple, fluent way - sahli mumtane - easily impossible. In the past, many Persian poets have written analogies to his works. But no artist has reached the level of Rudaki. In particular, 120 poets from the classics of Persian-Tajik literature wrote nazira in the Bukhara poem, which begins with "Boyi joyi Moliyon oyad hame ...". But none of them reached the level of the original text: those who found the weight, the tone, stumbled on the subject, and those who were able to target the subject, did not succeed in music, rhyme ...

That is why the great word artists of the past valued Rudaki's genius and praised his poetic power. In particular, the great lyric poet, the first royalist Daqiqi describes it as follows:

$$
\begin{aligned}
& \text { G'azal rudakiyvor bo'lgay go'zal, } \\
& \text { Rudakiycha g'azal yoza olmadim. } \\
& \text { Juda nozik xayol bilan urinib, } \\
& \text { Bu parda ichiga yo'l topolmadim[4]. }
\end{aligned}
$$

Abu Abdullah Rudaki will always serve the people with the ideas of patriotism, enlightenment, friendship of peoples that he sang. The poet's work has been very close to the Uzbek people since ancient times. In Rudaki's works, confidence in the human intellect is strong. The language of his works, the means of artistic expression are described in a simple and clear way. He was the first to establish Persian classical literature in the 10th century, and many Iranian scholars, including Professor Sayyid Nafisi, consider Movarounnahr to be the birthplace of Persian poetry. [5]

\section{CONCLUSION}

In Rudaki's ghazals, human science is approached from the point of view of divinity. The language of his works, the means of artistic expression are written in a simple and understandable way. Since he was the first to establish Persian literature as early as the tenth 
Published: May 30, 2021 | Pages: 76-79

century, many Iranian scholars, including Professor Sayyid Nafisi, consider the birthplace of Persian poetry to be Movarounnahr.

\section{REFERENCES}

1. Мирзаев А.М. Рудакий,Москва,1968, С-45

2. Мухаббат тароналари. Рубоийлар (Форс-тожик тилидан Э.Очилов таржималари). T, 2005.5-25

3. ัша acap, Б-28

4. Мухаббат тароналари. Рубоийлар (Форс-тожик тилидан Э.Очилов таржималари). T, 2005. 5-35

5. Нафиси С., Ахвал ва аш'аре Абу Абдаллах-Джафар... Рудаки, т. 1-3, Техрон, 1310-19. Б28

6. Bakhromovich, S. I. (2018). Social and philisophical performance of making youth's intellectual culture. European science review, (7-8). 


\title{
LOCAL AREA ASPECT ON THE ON-FIELD DIVERSIFICATION OF SIX MAJOR BRAN AND HUMIDITY CHANGE IN BHUTAN
}

\author{
Kanawha K. Chaugai \\ Department Of Agriculture,Tribhuvan University, Nepal
}

\section{ABSTRACT}

Subsistence Bhutanese ranchers spread across various agro-biological zones keep up huge species and varietal variety of various harvests in their homestead. In any case, no examinations have been embraced at this point to evaluate why ranchers ration and keep up huge agrobiodiversity, the degree of agro-environmental wealth, species extravagance, assessed loss of customary assortments and dangers to the deficiency of on-ranch agro-biodiversity. Data on the quantity of assortments developed by the ranchers for six significant staple harvests were gathered from nine locale and twenty sub-regions spread across six distinctive agro-natural zones of the nation to comprehend ranchers explanations behind keeping up on-ranch crop variety, gauge agro-environmental wealth, species extravagance and the general loss of customary assortments, to realize the famers' degree of mindfulness on environmental change and the various dangers to trim variety. The outcomes from this examination demonstrated that a mindboggling $93 \%$ of the respondents oversee and use agro-bio diversification for family food security and occupation. The normal agro-environmental extravagance went from 1.17 to 2.26 while the normal species lavishness went from 0.50 to 2.66. The normal agro-biological wealth shows a huge agro-environmental heterogeneity as far as the various types of staple yields developed.

KEYWORDS: agro-biodiversity; environmental change; resource cultivating; normal agrobiological lavishness;

\section{INTRODUCTION:}

Bhutan addresses a delicate uneven biological system and is a most un-created country. The economy of the nation is one of the world's littlest and keeps on relying considerably upon the Renewable Natural Resources RNR area that contains Forest, Agriculture and Livestock. The RNR 
area represents about $15.7 \%$ of the all out GDP. The job of more than $69 \%$ of the populace is subject to the RNR area. The nation is situated in the southern slants of Eastern Himalayas between scopes $26^{\circ} 42^{\prime} \mathrm{N}$ and $28^{\circ} 14^{\prime} \mathrm{N}$, and longitudes $88^{\circ} 44^{\prime} \mathrm{E}$ and $92^{\circ} 07^{\prime} \mathrm{E}$. The nation has an absolute topographical space of $38,394 \mathrm{~km} 2$ of which about $70.46 \%$ is under timberland cover with just $2.93 \%$ of the all out region accessible for development . Rice, maize, wheat, grain, buckwheat and millets are significant staple bran developed by ranchers. Bhutanese ranchers are to a great extent little holders, negligible and practice a self-supporting, incorporated and means agrarian creation framework. The normal land holding is three sections of land on which ranchers grow an assortment of harvests under various cultivating practices and back domesticated animals to meet their family food security. Notwithstanding little ranch size, ranchers develop numerous kinds of harvests and assortments where homestead level agro-bio diversification is the foundation for supportable resource horticulture. In Bhutan where means cultivating is as yet prevailing, agro-bio diversification assumes a urgent part for practical agrarian turn of events, food security and destitution lightening. Bellon has noticed that agro-bio diversification is the premise of food security both in means and mechanically progressed horticulture creation frameworks. The Bhutanese horticultural creation can be delegated an exemplary "little holder framework" since it partners with the vast majority of the trait of a little holder. A little holder is described by little ranch size less of than 10 hectares; the greater part of the cultivating is attempted utilizing family work; the significant segment of the produce is utilized for family utilization with little excess available to be purchased that give them the money pay .

\section{THE MAIN FINDINGS AND RESULTS}

This investigation was attempted as one of the critical cycle for the detailing of SAP for preservation of oats. A cross country local area weakness appraisal study was completed in 2013 covering the five primary agro-biological zones of the country. This examination was embraced through coordinated effort between the NBC, the Regional Research and Development Centers RDC, Dzongkhag locale and Geog Sub-area, horticulture expansion staff and ranchers. The targets of this examination were to comprehend why ranchers monitor and keep up agro-biodiversity, the degree of agro-environmental lavishness, normal species extravagance and the assessed loss of conventional assortments and dangers to the deficiency of on-ranch crop species variety in the country. 


\section{CONCLUSION}

This investigation brings into light the view of the ranchers on the status and meaning of on-ranch varietal variety of six staple yields and environmental change dependent on their encounters. It is evident that family food security and vocation of the resource Bhutanese ranchers to a great extent depends on the on-ranch agro-bio diversification which gives yields and assortments that have explicit transformation for the different danger inclined cultivating conditions spread across five diverse agro-natural zones. This examination likewise shows that resource Bhutanese ranchers actually keep on developing various sorts of staple harvests and their assortments in their homesteads keeping a rich on-ranch agro-bio diversification across various agroenvironmental zones. The normal agro-biological wealth assessed in this investigation shows a more extensive agro-environmental heterogeneity which decides the sorts and degree of yields developed. Some agro-biological zones like the dry-subtropical agro-natural zone develop more harvests and their assortments when contrasted with other agro-environmental zones.

\section{REFERENCES}

1. . National Soil Service Center and the Policy and Planning Division. Land Cover Assessment Report; National Soil Service Center and the Policy and Planning Division, Ministry of Agriculture and Forest: Thimphu, Bhutan, 2011.

2. National BiodiversificationCenter. Draft National Strategic Action Plan for Cereals; National BiodiversificationCenter, Ministry of Agriculture and Forest: Thimphu, Bhutan, 2013.

3. Tsenter, J.; Grigoriadis, S. Conceptualizing intercessions to help on-ranch hereditary asset preservation. World Dev. 2003, 32, 159-173.

4. .Food and Agriculture Organization (FAO). Smallholders and Family Farmers. Accessible on the web: http://www.fao.org/fileadmin/layouts/nr/sustainability_pathways/docs/Factsheet_SMALL HOLDERS.pdf (got to on 11 April 2013).

5. Moussaieff, A.; Shein, N.A.A The effect of environmental change on smallholder and means horticulture. Proc. Natl. Acad. Sci. USA 2008, 104, 19680-19686. 
Published: May 30, 2021 | Pages: 80-83

6. National Environment Commission. Public Adaptation Program of Action; National Environment Commission, Royal Government of Bhutan: Thimphu, Bhutan, 2007. 


\title{
THE CONCEPT OF SOCIAL ACTIVITY AND ITS IMPORTANCE IN SOCIAL DEVELOPMENT
}

\section{Dilnavoz Tursunova}

\author{
Lecturer \\ Department of Preschool Education \\ Fergana State University \\ E-mail: alfargoniy.uz@gmail.com
}

\begin{abstract}
The article analyses the views of scholars on the concept of social activity and its various manifestations, and is based on the views on the reflection of social activity in the legislation.
\end{abstract}

KEYWORDS: social activism, national values, universal values, external activism, internal activism, youth activism

\section{INTRODUCTION}

The main factor in further enhancing the status of women in our country, increasing their socio-political activity, ensuring their participation in the ongoing reforms in the country is the harmony of education and upbringing, which can be identified as follows: First, national and universal to give notions of socio-political values, including values; Second, the use of modern means of methods that evoke the feeling that children in preschool education are future participants in the political life of the country; Third, general secondary education to teach high school students in subjects aimed at increasing their need for socio-political knowledge; Fourth, to encourage scientific, theoretical and practical activities related to the study of political and legal culture in higher education and beyond, with the establishment of broad cooperation between educational institutions and government agencies; Fifth, to ensure the participation of young girls in socio-political events, not limited to cultural facilities (cinema, theater, museums, etc.) in the formation of their spiritual outlook, to increase their participation in debates in these areas; Sixth, ensuring the active participation of women in the ongoing reforms in our country, the 
Published: May 30, 2021 | Pages: 84-87

formation of a sense of involvement of young girls in events in society is also the basis of our work in this direction.

\section{THE MAIN FINDINGS AND RESULTS}

When we think about social activism, first of all, we give examples from the opinions of different scholars about activism, activity. Activity (from the Latin word "actus" - action, "activus" - active) is the most important and common feature of a person who maintains a constant relationship with society, self-awareness and coordination of every action. A) External activity is the activity that can be seen and recorded directly from the outside and under the influence of our inner desires, the activity that is manifested through the movements of our muscles. B) Internal activity - on the one hand, it includes physiological processes during metabolism (metabolism, blood circulation, respiration, pressure changes, and on the other hand, direct mental processes, ie factors that actually do not appear, but affect the functioning Researcher K. Turgunov described activity as follows: "Activity is an important ability of a person to change reality to meet their needs. Activity is involuntary and voluntary, and is manifested in human activity - work, study, social life, sports, creativity, etc. So, activity is manifested in personal life, in a group, in a neighborhood, in a district, in a region, in a republic, in a society.

The overall structure of activity is determined by needs. Man's needs are the source of his activity. There are life needs (human needs as a living being), social needs (social development needs, as well as an individual's adaptation needs to society) and spiritual (enlightenment, religious, moral, aesthetic, etc.) needs. The diversity of needs determines the diversity of human activities. The most important factor underlying the classification of types of activity is the difference in the subjects to which it is directed and constitutes the motive of activity. Activity is not without motives, "unmotivated" activity has a subjective hidden motive.

On the basis of decrees and resolutions adopted by the Government of the Republic of Uzbekistan on the protection of the rights and legitimate interests of women, strengthening their health and creating decent working and living conditions, protection of motherhood and childhood, strengthening the family, improving social and living conditions and a number of other issues. work is underway. In particular, it is no 
Published: May 30, 2021 | Pages: 84-87

exaggeration to say that the Decree of the President of the Republic of Uzbekistan dated February 2, 2018 PF-5325 "On measures to radically improve the activities in the field of support of women and strengthening the family" marked a turning point in the activities of women's committees. Because this Decree has become one of the important legal bases protecting the interests of Women's Committees and women and families. One of the main tasks set out in the decree is to organize work with women living in difficult living conditions, especially women with disabilities, to study their problems and find solutions. This Decree marked a significant turning point in the activities of the Women's Committee system. Since the adoption of the decree, as in all areas, a number of measures have been taken to provide comprehensive support to women with disabilities in difficult situations, to study their housing and employment problems and to provide practical assistance. A total of 4,821 women in difficult living conditions were identified across the city, of whom 1,614 were women with disabilities and 2,798 were women in need of housing.

\section{CONCLUSION}

Society is also a space for man to realize his potential as a living space. After all, the development of society is directly related to human activity. In turn, this activity means that a person has the opportunity to improve and live for himself. Therefore, to make this opportunity a reality, a person strives to live well in his work, to build a model lifestyle. In turn, this activity has an impact on the development of society. In this regard, it can be said that increasing youth activism is one of the most important and urgent issues. We need to pay attention to the positive attitude of young people to the modern way of life. Youth activity depends on environmental factors, behavior, and so on. In this regard, intellectuals, especially public organizations and political parties, should take the lead. It should be noted that in our country, equipping young people with the necessary opportunities in the process of modernization of society and providing them with the necessary knowledge depends mainly on the intelligentsia.

\section{REFERENCES}

1. Каримова В.М., Акрамова Ф.А. Психология. -Т.: Ўқитувчи.20о0. Б- 48

2. Турғунов Қ. Психология терминларининг русча-ўзбекча изохли луғати. -Т.: Ўқитувчи. 1975. Б- 9-10. 
Published: May 30, 2021 | Pages: 84-87

3. Bakhromovich, S. I. (2018). Social and philisophical performance of making youth's intellectual culture. European science review, (7-8).

4. Сиддиков, И. Б. (2018). Социально-философские аспекты формирования интеллектуальной культуры молодёжи. Theoretical \& Applied Science, (1), 61-66. 


\title{
THE IMPORTANCE OF AESTHETICITY OF ECOLOGICAL CONSCIOUSNESS AND CULTURE IN THE ACTIVITIES OF PRESCHOOL EDUCATIONAL PROFESSIONALS
}

Oygul Ashurova

\author{
Researcher \\ Department of Preschool Education, \\ Fergana State University Uzbekistan \\ e-mail: alfargoniy.uz@gmail.com
}

ABSTRACT: The article expresses the views on the transfer of topics related to the aesthetics of environmental consciousness and culture in the activities of preschool education professionals.

KEYWORDS: ecological problems, ecological consciousness, transformation, aesthetic attitude, ontology, epistemology, methodology, praxiology

\section{INTRODUCTION}

Today, the solution of environmental problems that have emerged on a global scale remains one of the key conditions for preserving the future of human civilization. This, in turn, prevents the escalation and aggravation of environmental problems, to assess and organize the basics of human social, economic, political, cultural life in accordance with environmental requirements, modernize the theoretical and fundamental foundations of the forms of social consciousness and human activities. redevelopment in the context of environmental paradigms. The transformation of environmental consciousness and culture requires the development of governmental and non-governmental organizations and civic institutions responsible for technology, communication and infrastructure, the creation of constructive methods and tools that activate the role of the human factor in transforming environmental consciousness and culture.

\section{THE MAIN FINDINGS AND RESULTS}

In the fundamental theoretical knowledge of ecological existence, the ontological, epistemological, methodological and praxiological functions of aesthetics are manifested at different practical levels - as ecological activities based on simple everyday customs, traditions 
or complex technical-technological culture. In this regard, the organization of human attitude to being in general, especially to ecological being, on the basis of the principles of aesthetic culture, on the one hand, to determine the motives, methods of expression, differences (status and importance) from other forms of social consciousness; on the other hand, it requires the organization of the functional connections of the material and spiritual, theoretical and practical activities of different cultural spheres in nature protection on the basis of the laws of sophistication.

At present, the need and objective necessity to solve global environmental problems between different peoples and countries is intensifying the process of spiritual integration, leading to the globalization of the universal-eco-aesthetic way of thinking and the corresponding practical actions. This process, through the integration of environmental and aesthetic activities, creates opportunities to combat not only environmental problems, but also the social, economic, political and spiritual causes that give rise to them. Because the essence of the solution of environmental problems by artistic and aesthetic methods and means, the political, economic, legal, spiritual and ideological and other social relations of society in the interests of environmental protection, the goals and aspirations to change human "environmental qualities" representation in images.

At the present time, the day-to-day practical task of ecological aesthetics and ecological aesthetics is of an integrated nature, organizing and managing the continuous growth of material needs of society (formation of a culture of rational consumption); compensating for limited natural resources (creation of new, unconventional sources of environmentally friendly energy resources); increase the adaptability of organisms to the changing natural environment (in particular, increase the physical and mental adaptation potential of man); maintaining a stable and optimal ecological balance of the biosphere (ensuring the evolution of the system of "nature-society-human" relations). It is these tasks that reflect its human nature and perspective. In the formation of civil society, any level and form of economic consciousness is based on democratic and humanistic principles: to meet human needs, to achieve goals, to create mechanisms to protect social interests, to improve "technology". After all, it demonstrates its social essence by meeting human needs, achieving certain goals, defending various aspirations. 
Published: May 30, 2021 | Pages: 88-90

\section{CONCLUSION}

Both the process and the result of the aestheticization of ecological consciousness and culture determine the functional significance of forms of social consciousness aimed at strengthening the active vital position of the individual in the protection of nature, the rational use of its resources. Therefore, it is expedient to look at the process of aesthetic education and upbringing, aimed at the formation of ecological culture, as a whole, as a whole phenomenon. That is, environmental education is manifested at the same time on a rational and empirical level. Because the unity of material and spiritual, empirical and rational aspects in the system of ecological needs of man fully reflects its essence. But at certain stages of the development of society, in the system of human needs, the satisfaction of material needs (priority over spiritual needs had the status of a law.

\section{REFERENCES}

1. Мусурмонова, Ш. И. (2019). Инсонларнинг табиатга эстетик муносабатини шакллантиришда экологик таьлим тарбиянинг роли. Интернаука, (37), 91-92.

2. Ganisher Xasanovich, T. Student problems in the formation of aesthetic culture of students.

3. Айдаров Е. Б. Ўқувчи ёшларга маънавий-ахлоқий тарбия бериш орқали экологик маданиятни шакллантириш //Современное образование (Узбекистан). - 2019. - №. 8 (81). 


\title{
THE DIALECTICS OF RELIGIOUS AND WORLDLY TOLERANCE PRINCIPLES
}

\author{
Gayratjon Abdurahmonov \\ Senior Lecturer \\ Department of Social Sciences \\ Fergana Polytechnic Institute \\ E-mail: alfargoniy.uz@gmail.com
}

ABSTRACT: The article provides a dialectical analysis of the main conditions and factors of ensuring the balance of secularism and religiosity in the ideological unification of society.

KEYWORDS: secularism, religiosity, atheism, "Islamic democracy", secular ideology, ideology

\section{INTRODUCTION}

Religion recognizes the supernatural as the eternal and real world, and teaches that man's life in the real world is a means to the transition to the eternal world. Secularism, on the other hand, seeks to study and change the material world as an object. According to researcher T. Karim, people's attitudes to the world are manifested in four different ways: 1) religious bigotry; 2 ) religious tolerance; 3) secularism; 4) atheism [1]. For example, when religious bigotry prevails in a society, any secular principles are denied. At the same time, we have experienced that atheism also sees religion as an opium for society. In societies based on secular democratic values and principles, any form of tolerance, including religious tolerance, is ensured as an important value. Therefore, it is very important to ensure the priority of the principles of religious and secular 
Published: May 30, 2021 | Pages: 91-94

tolerance in the ideological unification of society, the formation of a tolerant attitude to the positions of religious and secular in the ideological unification.

\section{THE MAIN FINDINGS AND RESULTS}

It is also becoming a necessary task to link the democratic principles of Islam with secularism in the ideological unification of society. At present, the concept of "Islamic democracy" is also emerging as an ideology. But this idea cannot take on a truly secular character. This model has a religious content and cannot cover the common interests of all mankind. The manifestations of extremist and fundamentalist views in the guise of religion that are prevalent in Muslim countries today are diverse and consist of views that are essentially the same. That is, it reaffirms the philosophical rule that "one essence is manifested in many meanings, but content cannot be manifested in two or more essences." At the same time, the essence of any religious extremist and fundamentalist views is different, and consists of views that are essentially the same [2]. However, today, extremist and fundamentalist views, which are the main forces in causing social instability, also hinder the ideological unification of societies.

- The peculiarity of the path of democratic development aimed at unification on the basis of secular ideology is that they try to explain religion as a factor that serves social development, not to squeeze religion out of society, but to accept religion as an integral part of society. A special feature of a secular state is that the state is independent of religion and religious organizations, that no religion or ideology is established as an obligation, and that a dominant system is not allowed to emerge under the influence of a particular religion or ideology. To give a clear answer to this question, it is necessary to analyze the specific features of the secular state [3]. As a result of the study of the 
Published: May 30, 2021 | Pages: 91-94

scientific literature today, the following can be cited as the main paradigms of a secular democratic state:

- The independence of the state from religious and ideological sources is enshrined in law;

- No religious ideology should be allowed to oppose the absolute sovereignty of the state;

- Separation of religious associations from the state aimed at propaganda;

- Absence of compulsory religion or ideology;

- creation of legal conditions for free activity of religious organizations;

- equality of religious associations before the law;

- secular nature of the state education system;

- The inadmissibility of the establishment of religion or ideology [4]. Secularism and religiosity, based on freedom of will, conscious choice, and not on such coercion, form solidarity in society.

In order to create ideological unity in our society, ensure solidarity, protect against ideological aggression, prevent terrorism from creating social instability, President of Uzbekistan Shavkat Mirziyoyev signed a decree on September 19, 2018 "Improving the procedure for exempting citizens of the Republic of Uzbekistan from criminal liability." Decree No. 5542 "On According to him, citizens who got lost in the ranks of terrorist, extremist or other banned organizations and groups, including outside the Republic of Uzbekistan, realized the illegality of their actions and went on the path to recovery were given the opportunity to return to their homeland, family and peaceful life. This is one of the practical works aimed at forming solidarity in society.

\section{CONCLUSION}


Published: May 30, 2021 | Pages: 91-94

Understanding and studying religious ideas is one of the important factors in the ideological unification of society in the process of comprehensive reforms, raising our national consciousness, educating the younger generation to be religiously and secularly enlightened, respecting our national values. In the implementation of this process, the implementation of the main directions identified in the Action Strategy, which is a logical continuation of our national idea, will serve as a spiritual and educational tool to ensure the balance of secularism and religion in Uzbekistan.

\section{REFERENCES}

1. Карим Т. Дунёвийлик фалсафаси // Дунёвийлик фалсафаси: Мақолалар тўплами. Тошкент: ТДИУ, 2007. - Б. 26.

2. Карим Т. Дунёвийлик фалсафаси // Дунёвийлик фалсафаси: Мақолалар тўплами. Тошкент: ТДИУ, 2007. - Б. 23.

3. Понкин И. Понятийный аппарат в проблеме светскостигосударства и образования / / Государственная служба. — 2002, -№5. - С. 118.

4. Ўзбекистон Республикасининг Конституцияси. Тошкент.: Ўзбекистон. 2017. 19-21-б. / Смоленский М.Б. Конституционное (государственное) право России. Ростов н/Д: Феникс, 2002. -С.161.

5. Ўзбекистон Республикаси Президентининг 2018 йил 19 сентябрдаги “Террористик, экстремистик ёки бошқа тақиқланган ташкилот ва гурухлар таркибига адашиб кириб қолган Ўзбекистон республикаси фуқароларини жиноий жавобгарликдан озод этиш тартибини такомиллаштириш тўғрисида”ги Фармони. “Халқ сўзи”, 2018 йил 20 сентябрь. 


\title{
SELF-BUILD FLUORINATED STRUCTURANTS FOR SURFACE TREATMENT
}

\author{
Castaner, L \\ Department Of Applied Science, Curtin University, Australia
}

\section{ABSTRACT}

Another class of alkyl-and perfluoroalkyl-containing urea and amide subordinates was integrated from amino corrosive subsidiaries. The greater part of these mixtures showed superb gelation conduct in natural solvents at low focuses. A couple structures chose from the underlying screening were utilized for surface alteration of sinewy substrates to make hydrophobic and oleophobic composites. The hydrophobic and oleophobic practices of these composites were credited to a mix of expanded surface unpleasantness and the alkyl/fluorinated functionalities present in the spine.

KEYWORDS: Organogelator; gelation; perfluoroalkyl; urea; amide; amino corrosive; xerogel; nonwoven; hydrophobic.

\section{INTRODUCTION}

Low atomic weight structures (LAWOS) are acquiring expanded consideration because of their expected applications in an assortment of modern areas identified with materials, beauty care products, medical care, food and oil innovation. The plan and explanation of design property connections of gelators is likewise a significant space of examination, specifically, building up the connection between the compound construction of a gelator and its gelation properties in a given dissolvable. Thermally reversible actual gels are by and large shaped without anyone else get together of the gelator atoms in dissolvable, prompting the arrangement of a sinewy supramolecular network with the exemplification of dissolvable. This perplexing interaction of self-get together into supramolecular structures fluctuates dependent on the functionalities present in the organogelator and outer elements, including dissolvable, temperature, and $\mathrm{pH}$. Different non-covalent cooperations, for example, hydrogen holding, $\pi-\pi$ stacking, hydrophobic 
collaborations, and metal coordination, impact the development and adjustment of the organogelator self-congregations .

\section{THE MAIN FINDINGS AND RESULTS}

Nonetheless, the non-covalent powers impacting gelation are generally frail contrasted with covalent bonds, and a mix of a large number of these communications is needed to shape a solid intermolecular organization. Every particle of an organogelator can build up a few kinds of actual communications with an adjoining atom. For instance, intermolecular hydrogen holding ordinarily works with the development of straight, prolonged totals with dissolvable capture. Dissipation of dissolvable from a gel brings about the development of a dried gel (xerogel) with a sinewy or web-like morphology . It is feasible to adjust the surface morphology of the substrate, and accordingly surface properties, if the gelation and ensuing vanishing of dissolvable are performed on a substrate. Thus, gel impregnation system could give the low surface energies wanted for creating superhydrophobic surfaces . Surfaces on which the contact point of water surpasses $150^{\circ}$, and shows low contact point hysteresis, are portrayed as superhydrophobic or ultrahydrophobic . These surfaces repulse water like a lotus leaf and are likewise viewed self as 'cleaning', since any surface pollution is eliminated by water as the drops move across the surface. Oneself cleaning capacity of these surfaces is to a great extent because of the expanded surface region made by a two-level miniature and nano unpleasantness morphology

\section{CONCLUSION}

Another class of halfway fluorinated amides and urea-amides valuable as structurants was blended from amino corrosive structure blocks. These subordinates showed great gelation properties in an assortment of natural solvents, and overall the urea-amide subsidiaries were preferable gelators over the comparing bis-or tris-amide subsidiaries. Similar to urea-ester subsidiaries neglected to gel in any natural solvents, demonstrating a blend of urea and amide functionalities, or different amide gatherings, are alluring to instigate gelation. Great structurants got from the underlying screening were assessed for surface change of nonwoven substrates, and surface investigation showed a gel-impregnated surface with permeable microstructure 
morphology. Composites acquired by means of impregnation by gelators gave surfaces magnificent hydrophobic properties. The nonwoven surfaces impregnated with perfluoroalkylcontaining structurants showed incredible oleophobic conduct. Unrivaled hydrophobic and oleophobic conduct showed by these composites were credited to a mix of miniature organized surface morphology made by the xerogel and the presence of fluorocarbon/hydrocarbon functionalities in the gelator spine.

\section{REFERENCES}

1. Rubio, F.R.; Ortega, M.G.; Gordillo, F.;. Low-atomic mass gelators of natural fluids and the properties of their gels. Chem. Fire up. 1996, 97, 3133-3161.

2. Lopez-Martinez, M., Eds.Molecular Gels: Materials with Self-build Fibrillar Networks; Springer: Dordrecht, The Netherlands, 2007.

3. Lopez-Martinez, M. Atomic organogels. Delicate matter included low-atomic mass natural gelators and natural fluids. Acc. Chem. Res. 2006, 39, 489-497.

4. Alata, M.; Al-Nimr, M.A. New utilitarian materials dependent on self-amassing organogels: From luck towards plan. Angew. Chem. Int. Ed. 2001, 39, 2263-2267.

5. Choi, J.S.; Kim, D.Y.; Park, K.T.. Reversible self-get together of ensnared fluorescent gelators in polymerized styrene gel network: Erasable warm imaging through diversion of supramolecular designs. J. Am. Chem. Soc. 2008, 131, 15122-15122.

6. Choi, J.S.; Kim, D.Y.; Park, K.T.. Organogels: Properties and applications in drug conveyance. Des. Monomers Polym. 2012, 14, 95-107. 


\section{CHANGES OF COTTON'S NATURAL PROPERTIES IN THE PROCESS OF STORAGE}

\section{AND STORAGE}

\section{A`zamjon Dusmatov}

Master's Degree Student

Engineering Technology Namangan Institute of Engineering Technology

Sherzod Tokhtaev

Master's Degree Student

Engineering Technology Namangan Institute of Engineering Technology

Shaxboz Isaev

PhD student

Namangan Institute of Engineering Technology

Olimjon Sarimsaqov

Head of the Department of TTDIT, Namangan Institute of Engineering Technology, Professor

ABSTRACT: This study describes the problems caused by the distribution of the density of changes in the natural properties of cotton during ginning and storage in ginneries and their prevention.

KEYWORDS: cotton, fiber, seed, bale, density, bale, storage, injury, harvest,

\section{INTRODUCTION}

One of the problems in the cotton industry is the density of ginned cotton. The effect of the values on the technological properties of fiber spinning has not been studied.

In studying this situation, of course, it is important to know the effect of the spinning tape and the yarn on the technological properties of the fiber obtained from this cotton bundle. To date, this issue has not been studied in depth by technologists. 
Published: May 30, 2021 | Pages: 98-103

Figure 1 shows the distribution of the density of the layers according to the height of the baled cotton in the open and closed area. In both cases, the density of the layers varies from $60-80 \mathrm{~kg}$ / m3 to $225-350 \mathrm{~kg} / \mathrm{m} 3$. In order to study the change in the mass content of defects and impurities in the fiber with changes in density values in these layers, changes in the degree of mechanical damage to cotton seeds, changes in the length of the staple mass of fiber and changes in the amount of short fibers. Experiments were carried out on S-6524 selection cotton harvested by hand picking of $\mathrm{V}$ grade. The results obtained from the experiments are presented in the form of histograms in Figures 2, 3, 4 and 5, and in almost all of these histograms, the above-mentioned technological indicators show signs of shift, albeit partially, to a negative state. shows.

In addition, Table 1 shows a significant negative change in these indicators as a result of a decrease in the shelf life of cotton by more than 2 months (for variety B). From this it can be concluded that it is impossible to store IV-V grade cotton in a pile for more than 2 months.

As mentioned above, experiments were conducted on the equipment of the laboratory $\mathrm{HVI}-900$ in order to study the changes in the technological properties of fiber spinning. The results show that as the density of the layer increases, so does its length, as well as the linear and quadratic irregularities of the yarn. This is especially true when the density of the layer exceeds $200 \mathrm{~kg} / \mathrm{m} 3$. Therefore, the density of the ginned cotton should not exceed $200 \mathrm{~kg} / \mathrm{m} 3$, taking into account the technological parameters of spinning. 
Published: May 30, 2021 | Pages: 98-103

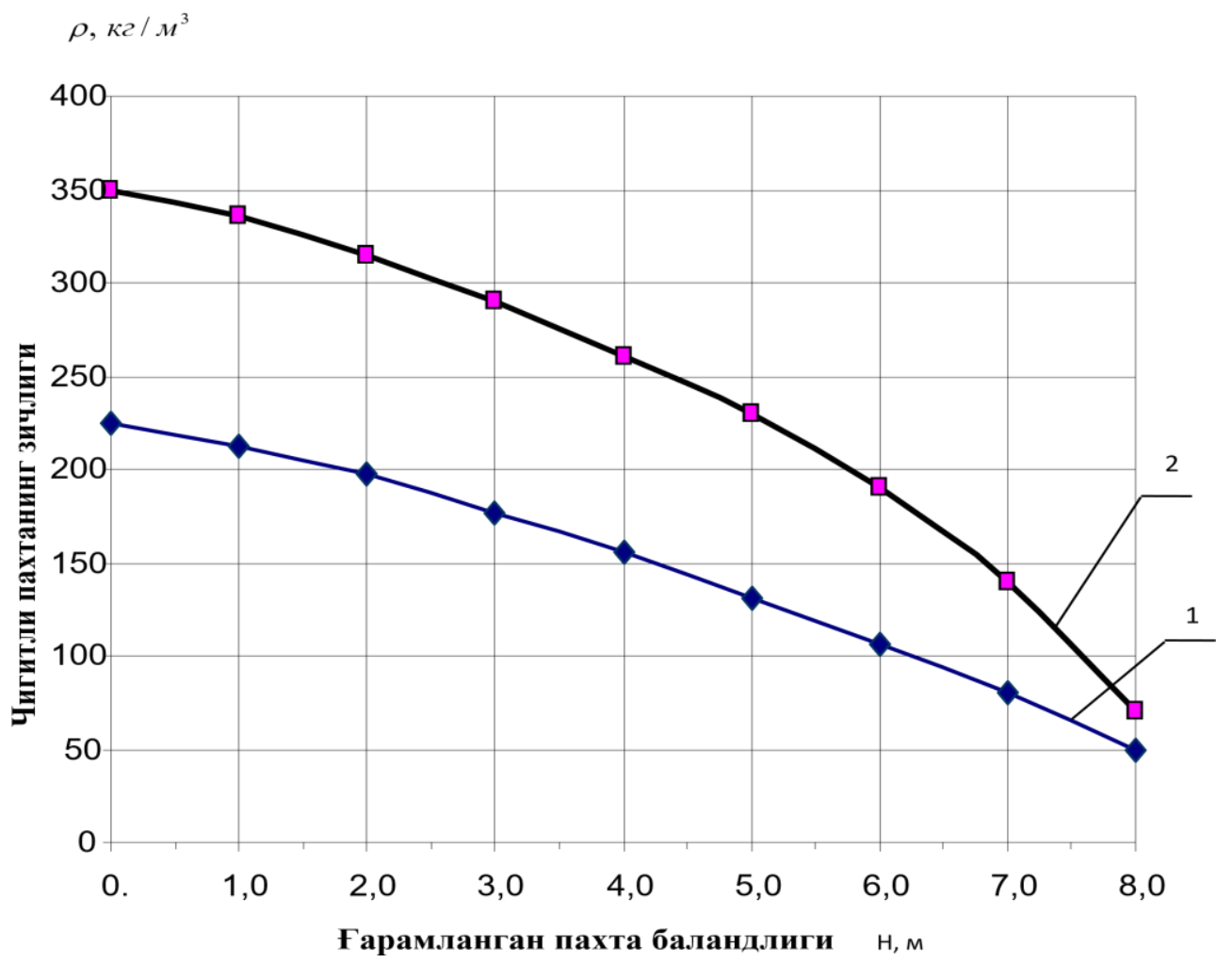

Figure 1. Distribution of cotton density during bagging

1- Distribution of cotton density when packing in a closed warehouse;

2- Distribution of cotton density in the open field

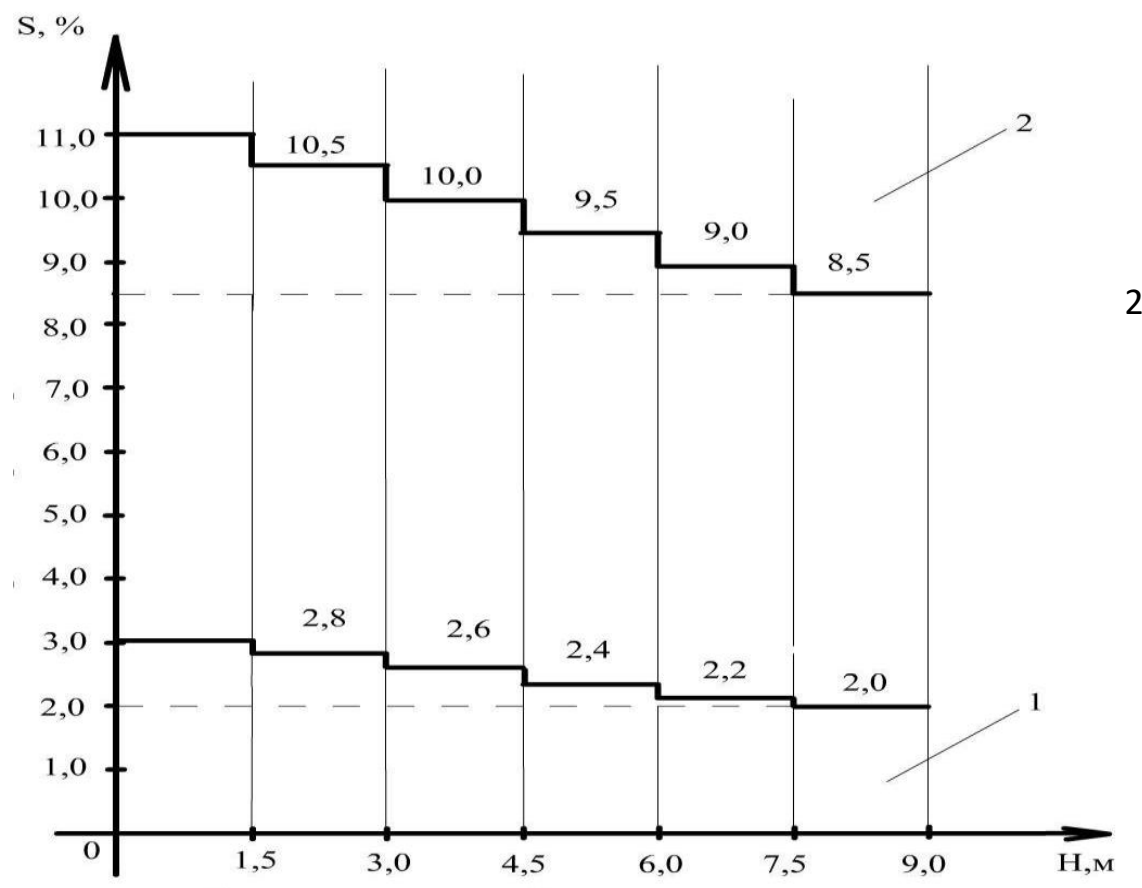

Figure 2. Defects in the fiber content and changes in the mass of impurities in the stacked cotton layers. 
Published: May 30, 2021| Pages: 98-103

1-II industrial grade hand-picked cotton $2-\mathrm{V}$ industrial grade hand-picked cotton

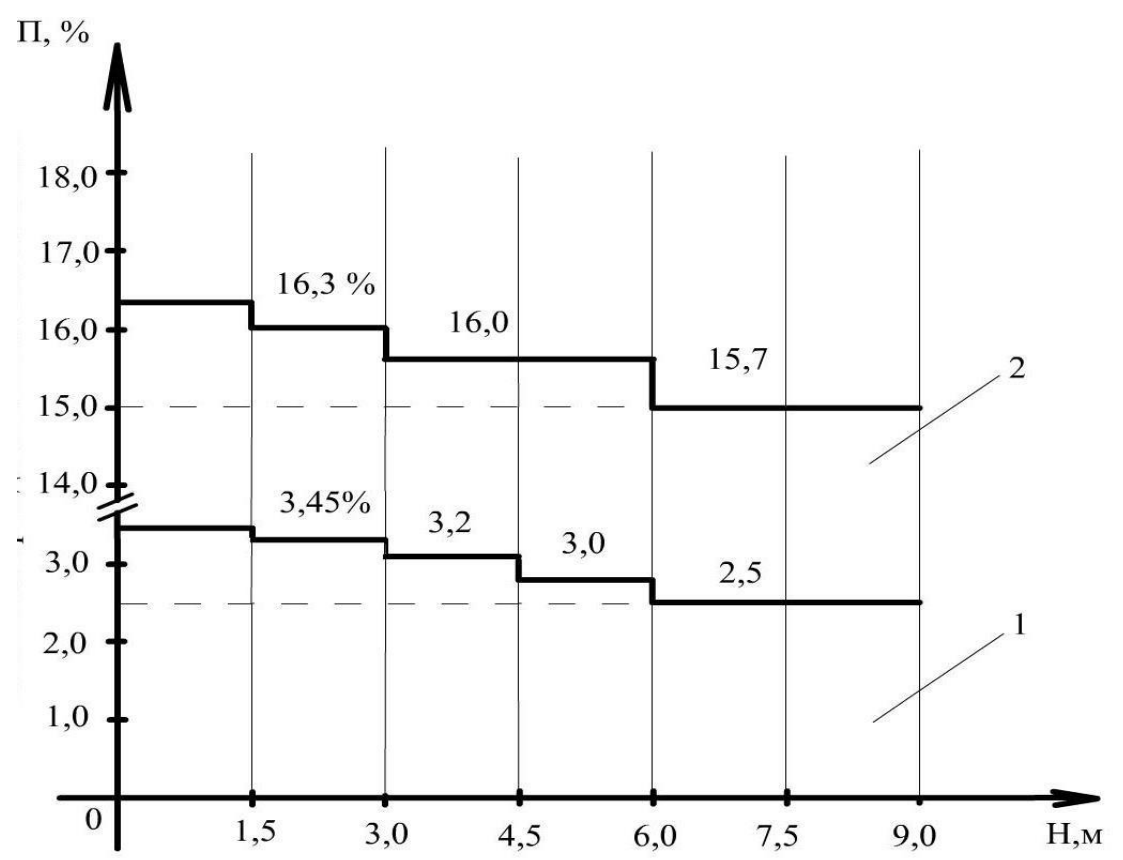

Figure 3. Degree of seed damage on stacked cotton layers

1-II industrial grade hand-picked cotton $2-\mathrm{V}$ industrial grade hand-picked cotton

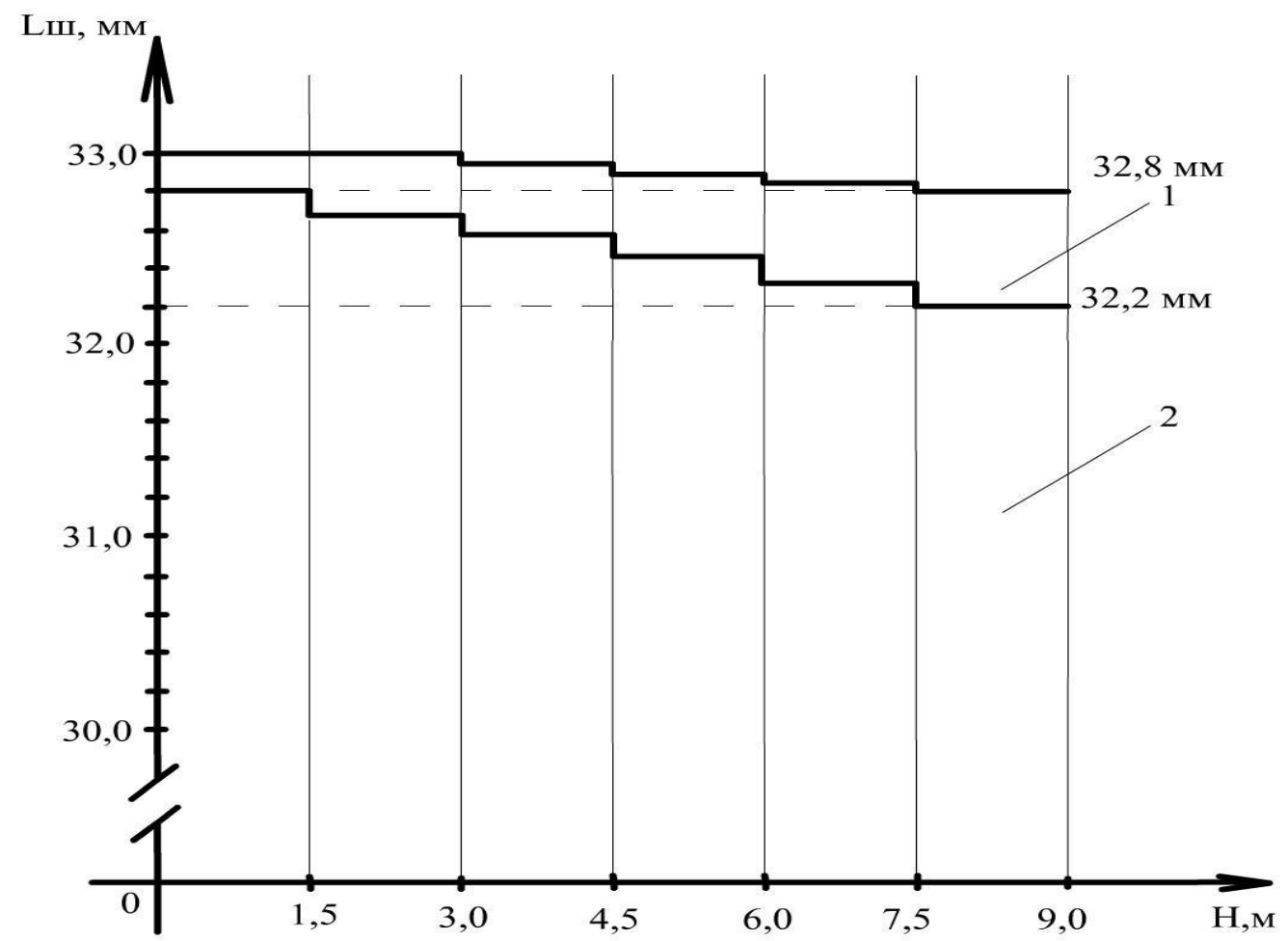

Figure 4. The change in the mass length of the fiber over the stacked cotton layers

$1-I I$ industrial grade hand-picked cotton $2-\mathrm{V}$ industrial grade hand-picked cotton 
Published: May 30, 2021 | Pages: 98-103

1. Table

The results of technological indicators of cotton .

\begin{tabular}{|l|l|l|l|l|l|l|}
\hline \multirow{2}{*}{ Fiber and seed performance } & \multicolumn{2}{l|}{ II--grade cotton } & \multicolumn{2}{l}{ V- -type Cotton } \\
\cline { 2 - 9 } & \multicolumn{2}{l}{ Shelf life,months } & \multicolumn{2}{l}{ Shelf life,months } \\
\cline { 2 - 9 } & $\mathbf{2 , 5}$ & $\mathbf{3 , 0}$ & $\mathbf{3 , 5}$ & $\mathbf{1 , 0}$ & $\mathbf{1 , 5}$ & $\mathbf{2 , 0}$ \\
\hline $\begin{array}{l}\text { Mass of defective and dirty compounds } \\
\text { in the fiber - S, \% }\end{array}$ & 2,24 & 2,5 & 2,8 & 10,2 & 10,5 & 12,5 \\
\hline $\begin{array}{l}\text { Degree of damage to cotton seeds - P, } \\
\text { \% }\end{array}$ & 2,5 & 2,65 & 2,8 & 16,2 & 21,2 & 28,0 \\
\hline Amount of short fibers - K, \% & 8,4 & 8,8 & 9,3 & 13,2 & 15,1 & 18,3 \\
\hline Staple mass length of fiber - Lsh, mm & 33,0 & 33,0 & 32,8 & 32,8 & 32,4 & 32,2 \\
\hline
\end{tabular}

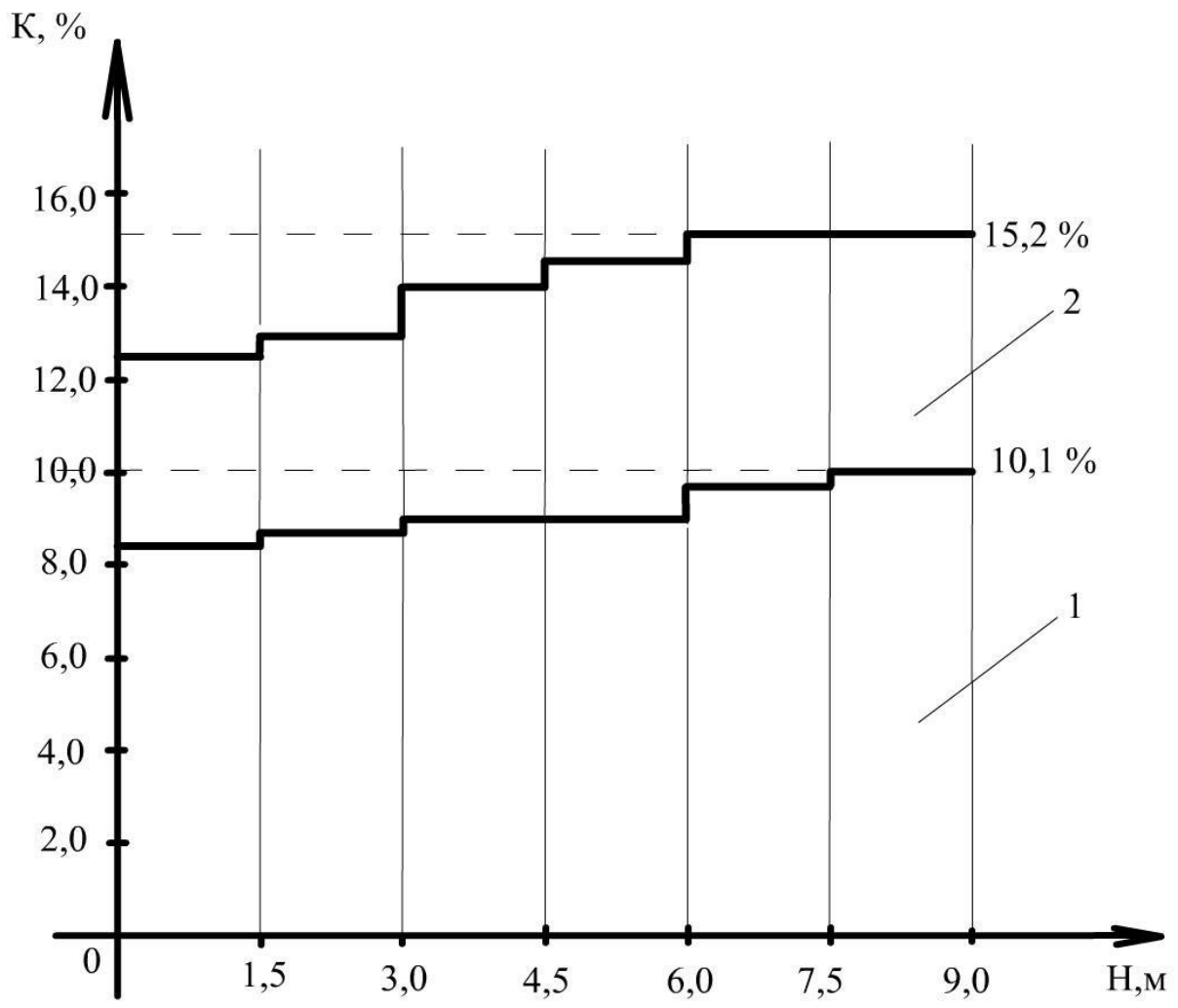

Figure 5. Changes in the amount of short fiber in the layers of cotton wool.

This means that when forming a bale of cotton in the open field, its height should be 5-6 meters instead of 8-9 meters, and grades III-V should be baled at a height of 2.5-3 meters instead of 4-5 meters, thus increasing the density. 'I should not be put. In a closed warehouse, the cotton is 
Published: May 30, 2021 | Pages: 98-103

poured at one point and shaped into a cone so that the densities in the substrate do not exceed $200 \mathrm{~kg} / \mathrm{m3}$, and the cotton is evenly distributed and distributed during the initial transfer, so that its density does not exceed $200 \mathrm{~kg} / \mathrm{m} 3$.

\section{CONCLUSION}

Therefore, based on the main purpose of any scientific work in this area, it is necessary not to allow the density of the cotton layer to exceed $200 \mathrm{~kg} / \mathrm{m} 3$ indoors or outdoors. This approach leads to the preservation of the natural properties of raw cotton. As a result, it is possible to ensure the quality of raw cotton during processing.

\section{REFERENCES:}

1."On the program of modernization and reconstruction of ginning enterprises for 2007-2011." Resolution of the Cabinet of Ministers of the Republic of Uzbekistan. 2007 y. No. 14. www.Lex.uz

2.Cotton, organization of its reception and storage.2014 y. www.Paxtasanoatilm.uz

3.Quality assessment in the reception of the cotton crop is the basis for a fair determination of the purchase price.2021 y. www.Agroinispektsiya.uz

4.Khodjiyev M.T., Razykov R.S., Salimov A.M. Preparation khlopka-syrsa k xraneniyu // Xlopkovaya prombshlennost, 1992, №5-6, S.14-16.

Results of technological indicators of cotton 


\title{
STABILITY ANALYSIS AND STUDY OF ETHYLENE GLYCOL MONOMER AND DIMER COMPLEX
}

\author{
Abubakir Shermatov, \\ Master degree Student, \\ Samarkand State University of Uzbekistan \\ g-mail: abubakir.shermatov.98@gmail.com \\ Mirjavokhir Mirov, \\ Master degree Student, \\ Samarkand State University of Uzbekistan \\ Shakhzod Tojiyev, \\ Master degree Student, \\ Samarkand State University of Uzbekistan
}

\begin{abstract}
A detailed theoretical study of ethylene glycol molecule have been performed by Hartree Fock (HF) method, second-order Møller-Plesset perturbation theory (MP2), and density functional theory (DFT) using $6-311++G(d, p)$ basis set. Geometrical parameters, interaction energies, deviation of potential energy curves of hydrogen bonded $\mathrm{O}-\mathrm{H}$ from that of free $\mathrm{O}-\mathrm{H}$, and charge transfer have been studied to analyze stability and nature of hydrogen bond formation molecule of ethylene glycol dimer complex.
\end{abstract}

KEYWORDS: ethylene glycol, monomer, dimer, interaction energy, frequency, charge transfer, distance of atoms.

\section{INTRODUCTION}

Ethylene glycol is applied extensively as drag delivering medium in medical industry and gas hydrate inhibitor in petroleum industry. Experimental study of ethylene glycol molecule and 
Published: May 30, 2021 | Pages: 104-107

ethylene glycol aqueous solution has been performed using nuclear magnetic resonance (NMR) spectroscopy [1], infrared spectroscopy (IR) [2], ultraviolet (UV) spectroscopy [3], Raman Spectroscopy [4], X-ray, and Neutron diffraction techniques [5]. Geometry optimization and interaction energy calculation have been carried out using Hartree Fock (HF) method, secondorder Møller-Plesset perturbation theory (MP2), density functional theory (DFT). In the study of molecular complexes in ethylene glycol liquids, the causes of changes in bond lengths, charge transfers, and angles of the monomer and dimer states of the molecule were studied.

Table 1: Ethylene Glycol monomer (Figure-1a) calculated distance of atoms ( $\mathrm{d}_{\mathrm{X}-\mathrm{\gamma}, \AA} \AA$ ), angle of bonds ( $A_{x-Y-z,}$ degree), atomic charge $\left(q_{x}, e\right)$ using 6-311++G(d,p) basis set.

Parameters

Methods

$\begin{array}{lll}M P 2 & \text { DFT }\end{array}$

do-H,

0.96

0.96

0.94

$\mathrm{O}_{4}-\mathrm{H}_{10}$

$\mathrm{A}_{\mathrm{H}-\mathrm{O}-\mathrm{C}}$

108.57

108.95

110.32

$\mathrm{H}_{10}-\mathrm{O}_{4}-\mathrm{C}_{2}$

$\mathrm{q}_{\mathrm{H}}, \mathrm{H}_{10}$

0.246

0.267

0.234

qo, $\mathrm{O}_{4}$

$-0.491$

$-0.446$

$-0.511$

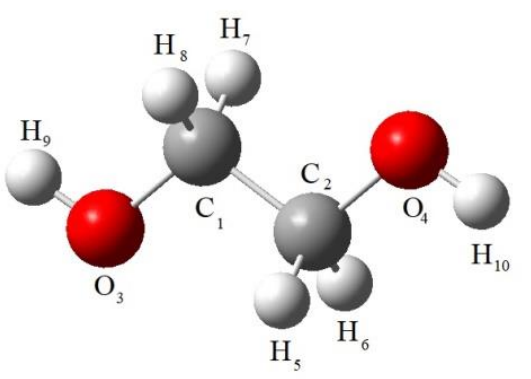

a)

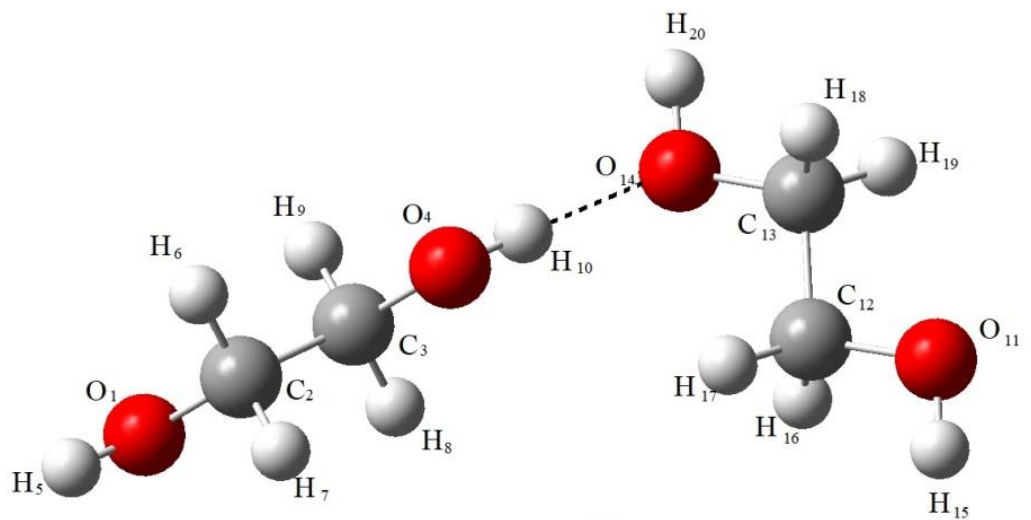

b) 
Published: May 30, 2021 | Pages: 104-107

Figure 1: Optimized structures using $B 3 L Y P / 6-311++G(d, p)$ of $(a)$ ethylene glycol monomer, (b) ethlene glycol dimer, (colour legend: red = oxygen, black = carbon, and whitish grey = hydrogen, and black-dotted is hydrogen bond)

Interaction energy $(\Delta E)$ for hydrogen-bonded complex is calculated as the difference between the energy of hydrogenbonded complex and the summation of the energies of each component monomer as

$\Delta \mathrm{E}=\mathrm{E}_{\text {complex }}-\sum \mathrm{E}_{\text {components }}$

where $\mathrm{E}_{\text {complex }}$ and $\mathrm{E}_{\text {components }}$ optimized energy of hydrogen-bonded complex and each individual component monomer, respectively.

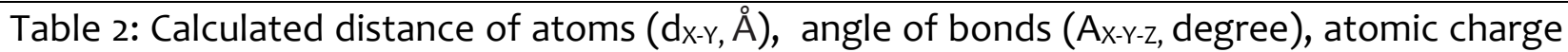
$\left(q_{x}, e\right)$, hydrogen-bond energy $(\Delta E$, $k c a l / m o l e)$ using 6-311++ $G(d, p)$ basis set.

\begin{tabular}{llll}
\hline Parameters & $\mathrm{MP2}$ & DFT & $\mathrm{HF}$ \\
$\mathrm{d}_{\mathrm{O}-\mathrm{H},}$ & 0.98 & 0.97 & 0.97 \\
$\mathrm{O}_{4}-\mathrm{H}_{10}$ & & & \\
$\mathrm{~d}_{\mathrm{O}} \cdots \mathrm{H}$, & 1.92 & 1.91 & 1.91 \\
$\mathrm{O}_{14} \cdots \mathrm{H}_{10}$ & & & 110.07 \\
$\mathrm{~A}_{\mathrm{H}-\mathrm{O}-\mathrm{C}}$ & 109.06 & 109.14 & \\
$\mathrm{H}_{10}-\mathrm{O}_{4}-\mathrm{C}_{3}$ & & & 109.02 \\
$\mathrm{~A}_{\mathrm{H}-\mathrm{O}-\mathrm{C}}$ & 108.76 & 108.86 & \\
$\mathrm{H}_{5}-\mathrm{O}_{1}-\mathrm{C}_{2}$ & & & 0.409 \\
$\mathrm{q}_{\mathrm{H}}, \mathrm{H}_{10}$ & 0.422 & 0.418 & 0.279 \\
$\mathrm{q}_{\mathrm{H}}, \mathrm{H}_{20}$ & 0.284 & 0.289 & -0.558 \\
$\mathrm{qo}, \mathrm{O}_{4}$ & -0.565 & -0.560 & -0.524 \\
$\mathrm{qo}, \mathrm{O}_{14}$ & -0.522 & -0.520 & 5.17 \\
$\Delta \mathrm{E}$ & 5.20 & 5.18 & \\
\hline
\end{tabular}


Published: May 30, 2021 | Pages: 104-107

A thorough analysis of hydrogen-bond formation in ethylene glycol dimer complex has been performed based on interaction energies, potential energy curve for hydrogen-bonded O$\mathrm{H}$, structural parameters of optimized geometry, and charge transfer.

The bonding energy of the EG molecule in dimer formation is $5.18 \pm 0.02$ $\mathrm{kcal} / \mathrm{mole}$. In the charge distribution, too, the atoms involved in the formation of the hydrogen bond changed significantly more than in the monomer state, depending on the bonding energy in the dimer formation, which can be said to be a medium-hydrogen bond.

\section{REFERENCES}

[1] S. Lüsse and K. Arnold, "The interaction of poly (ethylene glycol) with water studied by $1 \mathrm{H}$ and $2 \mathrm{H}$ NMR relaxation time measurements," Macromolecules, vol. 29, no. 12, pp. 4251-4257, 1996.

[2] E. L. Hommel, J. K. Merle, G. Ma, C. M. Hadad, and H. C. Allen, "Spectroscopic and computational studies of aqueous ethylene glycol solution surfaces," Journal of Physical Chemistry B, vol. 109, no. 2, pp. 811-818, 2005.

[3] Z. JianBin, Z. PengYan, M. Kai, H. Fang, C. GuaHua, and W. XiongHui, "Hydrogen bonding interactions between ethylene glycol and water: density, excess molar volume, and Spectral Study," Science in China B, vol. 51, no. 5, pp. 420-426, 2008.

[4] C. Murli, N. Lu, Z. Dong, and Y. Song, "Hydrogen bonds and conformations in ethylene glycol under pressure," The Journal of Physical Chemistry B, vol. 116, no. 41, Article ID 306220, pp. 12574-12580, 2012.

[5] I. Bakó, T. Grósz, G. Pálinkás, and M. C. Bellissent-Funel, "Ethylene glycol dimers in the liquid phase: a study by x-ray and neutron diffraction," Journal of Chemical Physics, vol. 118, no. 7, pp. 3215-3221, 2003. 


\title{
UZBEKISTAN BANK SYSTEM
}

\author{
Mumtozbegim Kholmatova \\ Student, \\ Tashkent State University of Economics \\ Uzbekistan
}

ABSTRACT: The article aims at further reforming and upgrading the financial and banking system of the republic, ensuring the stability of the banking and financial system based on international experience, increasing the liquidity and financial stability of banks in accordance with international standards, enhancing the investment activity of commercial banks investment projects, further expansion of credit institutions' participation in financing, development of modern financial institutions, and development of regulator framework of financial and banking activities in accordance with modern requirements and international norms improvement of the legal framework.

KEYWORDS: banks system, financial intermediation, financial affordability, banking system of Uzbekistan.

\section{INTRODUCTION}

In its quarterly study, the Center for Economic Research and Reforms assessed the Activity Index of 31 banks in the country. Banks are divided into three groups: large banks with a government stake; competitive banks; centralized banks. In order to regularly assess the share of the private sector in banking assets, as well as the effectiveness of reforms and transformation processes in the banking sector, the Center for Economic Research and Reforms has developed the Bank Activity Index, which consists of two sub-indices: Index of financial intermediation and availability; Index of financial stability of banks. Currently, 32 commercial banks operate in the banking system of Uzbekistan. Of these, 13 banks have a state share in their authorized capital, 19 banks are private banks or banks with foreign capital. August, the Central Bank of Uzbekistan registered Anor Bank as the first digital bank. The first sub-index of the Banking Activity Index was the Financial Intermediation and Availability Index. In determining this indicator, special attention was paid to the ratio of savings and time deposits in the real sector of the economy to the total amount of loans, the share of funds 
Published: May 30, 2021 | Pages: 108-111

from other banks and financial institutions in total liabilities and the role of government funds in the formation of banks' assets.

Financial intermediation The ability of commercial banks to attract funds into the banking system and channel these funds to finance the most promising projects determines the activity of banks as financial intermediaries.Therefore, when assessing the activities of banks in the field of financial intermediation, attention was paid to the ratio of savings and term deposits to the total volume of loans, the share of funds received from other banks and financial institutions in total liabilities, and the importance of financial resources from the state. One of the indicators of financial intermediation is the ratio of deposits attracted from the real sector to loans. The higher this indicator, the more positive the Banking Activity Index and the less negative. As of 1 September 2020, the ratio of savings and term deposits to loans in the banking sector averaged $28 \%$ in 13 state-owned banks and 69\% in banks with private and foreign capital. These numbers show the importance of funds other than savings and term deposits for large state-owned banks in lending. In the 10 largest state-owned banks, the share of deposits and loans from other banks and financial institutions in total liabilities averages $58 \%$. In banks with private and foreign capital, this figure reaches $22 \%$. At the same time, the share of state funds in the structure of liabilities of large banks with a state share remains high. As of

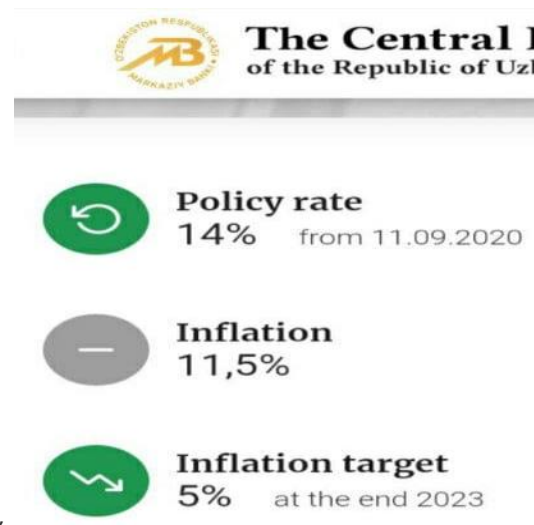

September 1,2020 , this figure was $19 \%$.

Financial affordability; The financial availability of banks shows how affordable financial services are for small and medium-sized businesses and the level of attraction of the "bankfree" population to the banking sector. Taking these factors into account, the number of entrepreneurs who received a loan can be considered as one of the criteria for measuring the availability of banking services for each bank branch. Ipak Yuli Bank, Agrobank and Hamkorbank have the highest indicators for this value. As of 1 September 2020, there were an average of 532 entrepreneurs per branch for each branch of Ipak Yuli Bank, while in Agrobank 
Published: May 30, 2021 | Pages: 108-111

and Hamkorbank this figure was 476 and 411, respectively. Another criterion for assessing financial affordability is the share of loans from the 10 largest clients in the total loan portfolio. In UzKDB Bank this figure was 78\%, in Ravnak Bank - 57\%, in Asaka Bank - 48\%.Kapitalbank retained its 1st place in the rating of the Banking Activity Index in the 3rd quarter of 2020. This bank has shown good results in financial intermediation, taking 3 rd place, in terms of financial availability in 4th place and profitability in 5th place. In particular, the share of savings and term deposits in the total volume of loans increased to $87 \%$, while the share of deposits and loans from other banks and financial institutions in total liabilities (3\%) and the share of public funds in liabilities (1\%) is much lower than on average across the banking system. The high financial inclusion index of Kapitalbank, in particular the low share of loans provided to the 10 largest clients, and the high ratio of loans to the private sector to the total volume of loans, put the bank in 4th place in this rating. Universalbank took 2 nd place in the overall rating. In particular, in the rating for financial intermediation, this bank took 4th place, 1st place for asset quality and 6th place for profitability. These indicators helped the bank move up 2 points in the overall rating. At the same time, the low results of Universalbank on capital adequacy show that the bank should pay special attention to the indicators of capital adequacy. Among banks with a state share in the overall rating, Ipoteka Bank rose by 2 points, taking 15 th place, Microcredit Bank - by 6 points (16th place) and Uzpromstroybank - by 4 points (19th place). These banks have seen positive developments in terms of financial intermediation and affordability. At the same time, in comparison with the indicators of May, the rating of the Halyk Bank fell from 11th to $13^{\text {th }}$ place. This is due to the fact that the bank's indicators for asset quality and management efficiency were lower than the average for the banking system. In particular, the share of problem loans of this bank in the total loan portfolio amounted to $4 \%$, the amount of profit per employee is 34.5 million soums (on average 64 million soums), the ratio of operating expenses to income is $53 \%$. Asaka Bank dropped 4 points and took 17 th place in the overall ranking. This is due to the fact that the volume of deposits and loans received by the bank from other banks and financial institutions increased by 1.4 trillion soums.

\section{REFERENCES:}

1.cbu.uz/eng nbu.uz The central bank Uzbekistan

2. Bank.uz Bank information.

3.info@stat.uz The state committee of the Republic of Uzbekistan on statistics. 
Published: May 30, 2021 | Pages: 108-111

4. Щелов, В. Банк, который всегда рядом / В. Щелов // Банковское дело. -- 2019. -- № 7. -- С. 48-49

5. https://www.worldbank.org/

6. https://cbu.uz/ 


\title{
FERMENTATIVE AND FIELD APPLY ADJUST: UTILIZING CURRENT PROOF TO MODEL ESTIMATES
}

\author{
Wellhöfer, $M$ \\ Department Of Applied Science, Universidad Autonomy Metropolitan, Mexico
}

\section{ABSTRACT}

Fermentative sway on worldwide field apply has been a disputable yet significant point. Up to this point, there has not been sufficient fermentative to have caused significant field apply adjust, so the proof from genuine worldwide field apply information has been sparse. Notwithstanding, in the previous decade, there have been 72 million hectares added to worldwide harvest cover. In this examination we exploit this new information to adjust the Global Trade Analysis Project (GTAP) model and boundaries. We roll out two significant improvements. To start with, we adjust the field adjust boundaries (called steady versatility of adjust, CET) to worldwide areas so the boundaries better mirror the real field cover adjust that has happened. Second, we adjust the field cover settling structure. In the old GTAP model, cropland, field, and timber field were all in a similar home recommending, all the other things being equivalent, that field or woods convert to crop field effortlessly and cost. In any case, we presently exploit the way that field converts to crop field at lower cost than woodland. The paper gives the hypothetical and exact legitimization for these two model upgrades. At that point it rethinks the worldwide field apply impacts becaapply of the USA ethanol program utilizing the improved model tuned with genuine perceptions. At long last, it shows that contrasted with the old model, the new model activities: less extension in worldwide crop field bec apply of ethanol development; lower U.S. share in worldwide crop field development; and lower woods share in worldwide crop field extension.

KEYWORDS: general harmony; fermentative; field apply adjusts; field adjust versatility; settling structure. 


\section{INTRODUCTION}

Field apply adjust instigated by human exercises is a significant wellspring of ozone harming substances (OHSs). Houghton assessed that around 1/3 of fossil fuel by-products delivered to the air since 1850 has come about becaapply of field apply adjust. Ramankutty and Foley assessed that the normal yearly pace of deforestation was about 4.25 MH during the time-frame of 18501990. The yearly pace of deforestation has expanded to 8.3 MH in 1990 and afterward diminished to 5.2 $\mathrm{MH}$ during the previous decade [3]. Extension in crop fieldis the significant wellspring of field adjust and deforestation. Generally, the extension in crop field has happened to fulfil the requirement for greater levels of popularity for food and fibre items. During the previous many years a few nations all throughout the planet have dispatched biofuel projects to deliver inexhaustible powers from agrarian assets.

\section{THE MAIN FINDINGS AND RESULTS}

A few papers have surveyed the financial and natural effects of these projects. The early papers distributed in this space proposed that the USA corn ethanol program could caapply significant field apply suggestions. Notwithstanding, the later investigations track down that the early gauges have exaggerated the field apply ramifications of this program . While research concentrates in this space have recognized and analyzed the significant components which decide the field apply effects of fermentative and their topographical circulations no endeavor has been made to approve the field apply gauges due to fermentative despite genuine perceptions .

\section{CONCLUSION}

Previous adaptations of the GTAP-BIO model accept uniform qualities for the field adjust flexibilities for all locales around the world. They likewise put timberland, field and crop field in one home and expect to be wood field and field field can be adjustd over to crop field with indistinguishable field adjust versatilities. In earlier work there was very little field apply adjust universally that could be utilized to align GTAP boundaries, however in the previous decade there has been considerable field cover adjust relating to the time of the fermentative blast. The real 
Published: May 30, 2021 | Pages: 112-114

field apply adjusts have differed altogether starting with one district then onto the next during the previous twenty years across the world. Furthermore, in genuine world changing wood field over to crop field is more exorbitant than changing field over to cropland.

\section{REFERENCES}

1. Diels, J.C.; Rudolph,. Updated appraisals of the yearly net transition of carbon to the climate from adjusts in fieldapply and fieldthe board: 1850-2001. Earth B2004, 55, 378-391.

2. Chang, Z.; Rundquist, A. Assessing authentic adjusts in worldwide fieldcover: Croplands from 1700 to 1993. Worldwide Biogeochem. Cycles1998, 13, 997-1028.

3.Global Forest Resource Assessment 2011; Food and Agricultural Organization of the United Nation: Rome, Italy, 2012.

4. Murnane, M.M. Arising Fermentative: Outlook of Effects on U.S. Grain, Oilseed, and Livestock Markets; Staff Report 07-SR 102; Center for Agricultural and Rural Development: Ames, IA, USA, 2008.

5. Spielmann, C.; Burnett, N.H.; Sartania, S Energy and Greenhoapply Impacts of Fermentative: A Framework for Analysis; Discussion paper 2008-2; Joint Transport Research Center: Berkeley, CA, USA, 2008.

6. Koppitsch, R.; Schnuerer, M.; Kan, C.; Lenzner, M.. Utilization of U.S. Croplands for Fermentative Increases Greenhoapply Gases Through Emissions from Land-Apply Adjust. Science 2009, 319, 1239-1241. 


\title{
THE IMPORTANCE OF EDUCATION IN THE FORMATION OF YOUTH CIVIL ACTIVITY
}

\section{IN THE HIGHER EDUCATION SYSTEM}

\author{
Xabibulla Muratov
}

Lecturer

\section{Karshi State University}

\section{Email:h.murodov1983@gmail.com}

ABSTRACT: At the current stage of development of our society, the activity of young people in the spiritual sphere consists in their conscious and creative realization of their active life position. Today's students are those who are preparing for the great tasks facing our country tomorrow. Consequently, student work is a mental work with its own characteristics, which means that it is reflected in excellent study, research and creative mastery of the basics of science. Such a position is to know the essence of the policy of building a free and prosperous homeland, a free and prosperous life in our country, a deep attitude to social events, an in-depth study of the priorities of social development, that is, a skillful combination of theory and practice. means the display of faith and moral qualities. This article can be useful as a resource for the study of the formation of civic activism of young people in higher education on the basis of a system-functional approach, the implementation of mechanisms to achieve quality and effectiveness of education.

KEYWORDS: Civilization, pedagogy, moral responsibility, democratic society, convention, worldview.

\section{INTRODUCTION}

Education is a pedagogical process organized for the purposeful development of the individual, which allows a systematic and systematic impact on the personality of the pupil. There have been many great figures in the history of Central Asia who have embodied emotional 
intelligence, spiritual courage, religious worldview and encyclopedic knowledge. Imam Bukhari, Imam Termezi, Khoja Bahovuddin Naqshbandi, Ibn Sino, A. Temur, M. Ulugbek, Babur and many other great ancestors made a great contribution to the development of our national culture and became the national pride of our people. As the President of the Republic Shavkat Mirziyoyev said: "Nothing in the great history goes unnoticed. It is preserved in the blood of nations, in the historical memory and in their practical work. Preservation, study and transmission of historical heritage from generation to generation is one of the most important priorities of our state policy. " If our students can objectively understand the genealogy, the contribution of their ancestors to world civilization, and correctly assess our historical values, they will have the intellectual potential to deeply observe that today's independence and independence have not been easily achieved. As you know, that on December 29, 2020, in the Address of President Shavkat Mirziyoyev to the Oliy Majlis and the people of Uzbekistan, he announced the name of 2021. Therefore, 2021 has been declared the Year of Youth Support and Health Promotion in our country. Today, the problems related to the life and development of young people have become one of the important factors in increasing the sense of responsibility of all, setting new goals and plans. In his speech at the 75th session of the United Nations, President Shavkat Mirziyoyev noted that today the world's youth is the largest generation in human history, numbering 2 billion, and, unfortunately, most crimes related to extremist activity and violence are committed by young people under 30. passed This shows that the issues related to the representatives of this stratum are one of the most important problems not only in Uzbekistan, but in the whole community. Today, globalization and intercultural mixing are taking place all over the world. This complex process affects not only young people but also the worldview of adults. On the one hand, information technology is entering our daily lives so fast that we can observe it without any numbers. Currently, more than 1,500 media outlets operate in the country. These media 
Published: May 30, 2021 | Pages: 115-119

contribute to the formation of information culture and ideological immunity of the younger generation.

\section{THE MAIN FINDINGS AND RESULTS}

Higher education has a profound effect on our economic, social, and spiritual development. Most importantly, the role of the social sciences is invaluable in instilling in students a new worldview, high spirituality, educating them in the spirit of devotion to the Fatherland, political vigilance, intolerance of destructive ideas. President Shavkat Mirziyoyev's proposal to adopt the UN Convention on the Rights of the Child at the UN was warmly welcomed by the international community, given that we are currently living with the largest number of young people in human history. Based on this, the Uzbek leader cited the fact that today the number of young people in the world exceeds two billion, and the need to protect young people at a time when international terrorism and extremism are growing rapidly. In his speech at the 72nd session of the UN General Assembly, President of the Republic of Uzbekistan Sh. Mirziyoyev said: "The future and prosperity of our planet depends on how our children grow up to be human beings. Our main task is to create the necessary conditions for young people to show their potential."

Sheikh Muhammad Sadiq Muhammad Yusuf's book, Social Etiquette, states: "In Islam, the issue of education and etiquette has risen to the level of worship. In all ages, in all lands, good-natured, noble, sweet, gentle people have been and will continue to be the beauty of society, the best of people. The Eastern world, in particular, has set an example for all mankind in this regard.

This article can be useful as a resource in the study of mechanisms for achieving quality and effectiveness of education, highlighting the practical and educational significance of the ongoing reforms in the education system, based on a systemic-functional approach to the formation of motivation, environment and education in demonstrating the position of civic activism in youth. People express their views, perceptions, values, aspirations, norms on personal and social values 
in different ways. Civic interests, which reflect the social interests of society, groups, the individual, become a system. It is precisely because it is a system that civic interests bring to life the values of each individual, shaping his or her attitude towards society, the state, and other citizens. It helps to define the responsibilities, goals, duties of the citizen, to form the features of social significance. Bringing up young people in a high moral and disciplined manner, their quality education and patriotic upbringing is the key to the economic and political development of the country. The following situations occur in the process of upbringing:

1. In the process of upbringing, the growth of the human organism takes place, things that cannot give a spontaneous effect on the environment are established. For example: A child can learn his native language under the influence of the environment. But he learns to read and write through special education. Certain knowledge, skills and competencies are acquired only in the process of upbringing.

2. With the help of upbringing, even some congenital defects of a person can be changed in the desired direction. For example, some children are born with certain disabilities (deaf, blind, dumb, etc.) but with the help of specially organized upbringing their minds are fully developed, they can be on an equal footing with people without birth defects.

3. With the help of upbringing, it is possible to eliminate the shortcomings caused by the negative impact of the environment (children play cards, swear, etc).

4. Education defines the future goal. It therefore plays an advanced role in ensuring the maturity of the individual.

\section{CONCLUSION}

In conclusion, educators, including educators, teachers, or coaches, need to be actors in life. Pre-school, general secondary or higher education should be treated appropriately. Being able to treat children as children and adults as adults is important in educating the younger generation. 
Published: May 30, 2021 | Pages: 115-119

They need to avoid all kinds of negative behaviors in the educational process, such as being treated rudely, being pressured or intimidated, or even being beaten. When educating young people, educators need to create the necessary conditions for young people to think and work independently, to express themselves fully, without any hesitation in the classroom.

\section{REFERENCES}

1. Sh.Mirziyoyev. Education and enlightenment are the path to peace and creativity. We will resolutely continue our path of national development and take it to a new level. Volume 1 . Tashkent. Uzbekistan 2017. p.29.

2. Speech by the President of the Republic of Uzbekistan Shavkat Mirziyoyev at the 72nd session of the UN General Assembly.

3. Sheikh Muhammad Sadiq Muhammad Yusuf. "Social etiquette" - Tashkent, "Hilal-Nashr". 2012. pp. 38-39

4. Pharoah. "The city of noble people." -T .: "A. Qadiri National Heritage Publishing House, $1993.162-p$

5. A. Munavvarov. "Pedagogy." Tashkent. "Teacher." 1996. Pages 25-38. 


\title{
THEORETICAL JUSTIFICATION OF THE PARAMETERS OF THE COMBINED MACHINE
}

\author{
Sanjar Toshtemirov \\ Doctor of Philosophy in Technical Sciences, Associate Professor \\ Department of mechanization of agriculture and service, \\ Karshi Engineering Economic Institute, Karshi, \\ Republic of Uzbekistan \\ Obidjon Khamroyev \\ Candidate of technical sciences, Associate Professor, \\ Department of mechanization of agriculture and service, \\ Karshi Engineering Economic Institute, Karshi, \\ Republic of Uzbekistan
}

\begin{abstract}
: the satya presents the features of the new technology of tillage and preparation of the field for sowing crops on the ridges. A design scheme was developed and a prototype of the combined unit and its device was prepared, as well as the details of the technological operations performed: simultaneous formation of the ridge, deep loosening of the soil along the line of the pre-formed ridge, local fertilization and the final formation of the ridge and irrigation furrows.
\end{abstract}

KEYWORDS: aggregate, ridge formation, soil, preparation, technology, seeding, screw body, ploughshare, deep reamer.

\section{INTRODUCTION}

In the world, the leading place is occupied by the development and application of energy-saving and high-performance machines for tillage and preparing it for sowing. "If we take into account that on a global scale, the area of land for sowing crops on the ridges is 120 million hectares" [1], then the development of energy-resource-saving technologies and machines with high quality of work and productivity for preparing the soil for sowing on the ridges is considered an important task. At the same time, much attention is paid to the development and use of combined machines that perform all 
the technological processes of tillage and preparing it for sowing on ridges in one pass through the field.

In the world, research works are being conducted aimed at developing new scientific and technical bases of resource-saving technologies for preparing fields for sowing on ridges. In particular, in this direction, it is relevant to conduct targeted scientific research on the development of a combined machine for preparing fields with harvested cotton stems for sowing seeds on ridges and substantiating the technological process of its working bodies, ensuring resource conservation in the processes of interaction with the soil.

Analysis of studies has shown that when preparing fields for sowing on ridges, improving the quality of processing, as well as reducing fuel, labor and other costs, can be achieved by using a combined unit that forms new furrows instead of existing ridges, new ridges instead of existing furrows in fields without cotton stalks [2].

\section{THE MAIN FINDINGS AND RESULTS}

The proposed technology is carried out in the following sequence: at the same time, the soil is loosened from the side parts of the right ridge of the existing row spacing, and the lower layer of the right side of the formed ridge is loosened linearly to a depth of $25-30 \mathrm{~cm}$, rotation of the upper layer of soil with a thickness of $10-12 \mathrm{~cm}$ of the existing right ridge to the left - to the right side of the middle of the existing row spacing and loosening of the lower part of the upper layer of the right ridge. Then, in this sequence, the soil is loosened in the lateral parts of the left ridge of the existing row spacing, and the lower layer of the left side of the formed ridge is loosened linearly to a depth of $25-30 \mathrm{~cm}$., rotation of the upper layer of soil with a thickness of $10-12 \mathrm{~cm}$ of the existing left ridge to the right-to the left side of the middle of the existing row spacing and loosening of the lower part of the upper layer of the left ridge. After that, the loosened lower soil layer of the right and left ridge is moved to the middle of the existing row spacing on the previously displaced upper layers. As a result, a new ridge with a deeply loosened lower layer is formed instead of the existing furrow, and a new furrow is formed instead of the existing ridge [3].

To substantiate the design scheme of the combined unit and the type of working bodies implementing the proposed technology, an analysis of the design of the units that prepare the fields for sowing seeds was carried out. As a result, a block diagram of the combined unit was developed for the implementation of the technology of preparing cotton fields for sowing seeds without cotton fields (Fig. 1). The combined unit consists of a frame 1; a mounted device 2; a support wheel 3; a deep 
loader with an inclined rack 4 and 5, left and right wrapping dumps 6 and 7; a ripper 8; ridging tool

9.
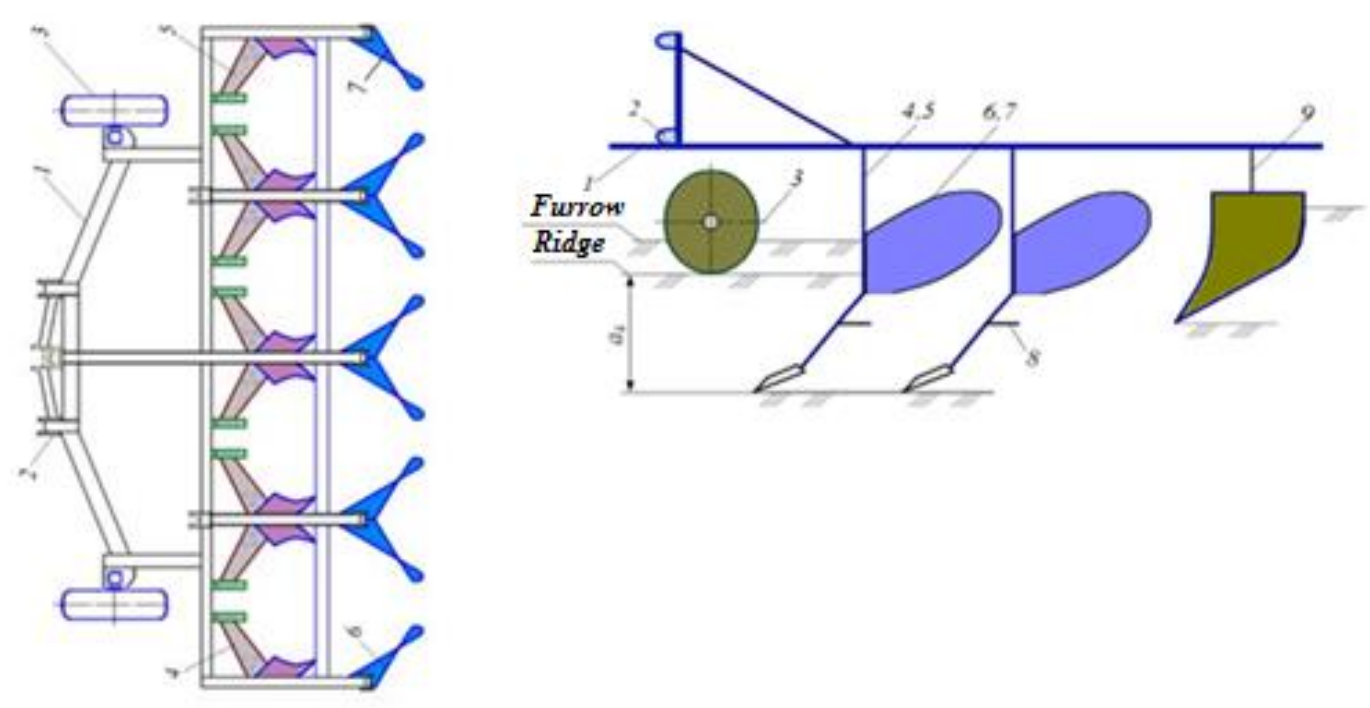

Fig. 1. Design diagram of the combined machine

A deep dredger with an inclined stand loosens the soil of the side parts of the right ridge, the existing row spacing and linear deep loosening of the lower layer of the right side of the formed ridge, its blade cutting off the top layer of the ridge soil wraps it to the left - to the right side of the middle of the existing row spacing, and the ripper loosens the lower part of the upper layer of the right ridge $[4,5,6]$.

The main parameters that affect the quality indicators and the traction resistance of the blade are the following (Fig. 2): $\mathrm{H}_{\mathrm{a}}$ - blade height; $\mathrm{b}_{\mathrm{a}}$ - blade grip width; $\mathrm{a}_{\mathrm{a}}$ - blade processing depth; $\varepsilon_{\mathrm{a}}$ - the angle of entry of the blade of the lower edge of the blade into the soil.

The parameters of the blade are determined based on the condition of cutting off half of the existing ridge and wrapping it in the existing furrow. On the basis of previous studies by scientists, the shape of the cross-section of the existing and formed ridge is assumed to be sinusoidal.

To form a new ridge of this shape instead of the existing furrow, it is necessary to cut a layer with a width from each half of the left and right ridge of the row spacing $b_{a}$ and thick $a_{a}$ and wrap them in the middle towards each other. Then the maximum blade width will be equal to:

$$
b_{a \min }=\frac{B_{M}}{4}-\frac{t_{y}}{2} .
$$

By expression (1) with the width of the row spacing $B_{M}=90 \mathrm{~cm}$ and the thickness of the rack of 
Published: May 30, 2021| Pages: 120-124

the working body with an inclined rack $t_{y}=$ the maximum blade width is $\mathrm{b}$ max $=21 \mathrm{~cm}$.
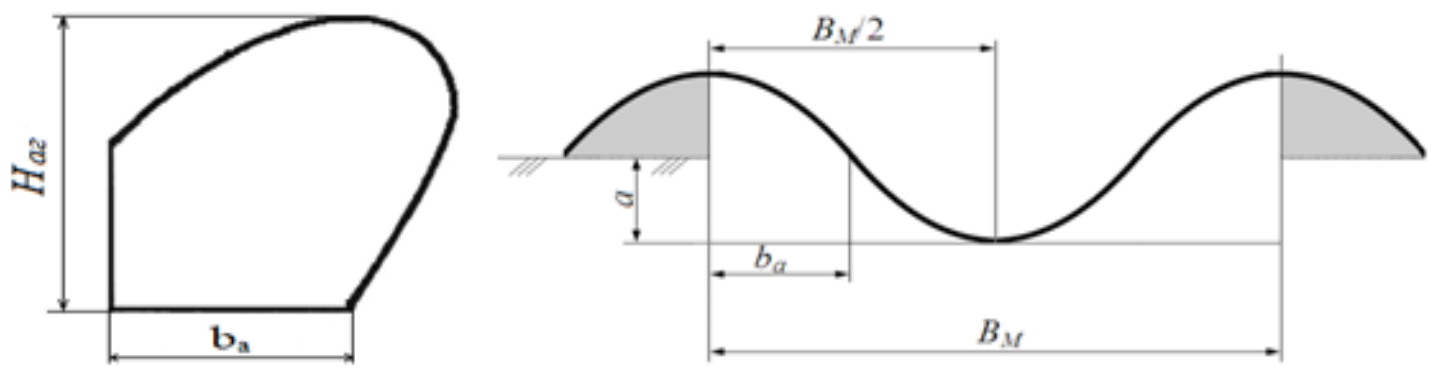

Fig. 2.The scheme for determining the width of the blade grip.

The maximum depth of processing of the dump is determined from the condition of stability of the laid layer, i.e., not overturning it obrotno.

$$
a_{a \max }=\frac{b_{a}}{1,27}=\frac{21}{1,27}=16,53 \mathrm{cM} .
$$

The height of the body was determined by the following expression

$$
H_{o m}=\sqrt{a_{a}^{2}+b_{a}^{2}} \text {. }
$$

By $a=12 \mathrm{~cm} \mathrm{~b}=21 \mathrm{~cm}$ according to expression (4), the body height must be greater than 23.32 $\mathrm{cm}$. We accept $\mathrm{H}_{\mathrm{OT}}=24 \mathrm{~cm}$.

\section{CONCLUSION}

According to the results of the theoretical studies carried out to prepare the fields for cotton sowing with minimal energy consumption and high quality of work is provided with a semi-screw blade design, a working width of $0.21 \mathrm{~cm}$, a processing depth of $0.12 \mathrm{~cm}$ and a minimum height of $0.24 \mathrm{~cm}$.

\section{REFERENCES}

1. http://www.nrcs.usda.gov

2. Тоштемиров С.Ж., Раззаков Т.Х.,Эргашев Г.Х. Энергоресурсосберегающая технология и комбинированный агрегат для подготовки полей к посеву хлопчатника // Academy, 2020. №3(54). C.7-10.

3. Тоштемиров С.Ж. Энергоресурсосберегающие технологии и комбинированный агрегат Аля подготовки почвы к посеву сельскохозяйственных культур на гребнях // Научный журнал. “Молодой учёный”. - Чита, 2017. - №29. - С. 27-29. 
Published: May 30, 2021| Pages: 120-124

4. Маматов Ф.М., Тоштемиров С.Ж. Новая технология и агрегат для подготовки почвы к посеву хлопчатника на гребнях // Научный журнал. “Молодой учёный”. - Чита, 2013. - № 10. - С. 259260.

5. Toshtemirov S.J, Mamatov F.M., Botirov Z.L., Chuyanov D.Sh., Ergashov G'.Kh., Badalov S.M. Energy-resource-saving technologies and machine for preparing soil for sowing // European science revive. - Austria, 2018. - № 3-4. - p. 273-240. (05.00.00; № 2).

6. Тоштемиров С.Ж., Раззаков Т.Х.,Эргашев Г.Х. Новая технология и агрегат для подготовки почвы к посеву // Научно-методический журнал. “Вестник науки и образования”. - Москва, 2021. №6 (109).- C. 25-29. 
Published: May 30, 2021 | Pages: 125-128

\section{THE ROLE OF MASS MEDIA IN TEACHING FOREIGN LANGUAGES}

\section{Oynisa Umirzokova}

\section{Master Student,}

\section{Samarkand State Institute of Foreign Languages, Samarkand, Uzbekistan}

ABSTRACT: This article aims to clarify the significance of Mass Media in educational environment, its role in teaching and learning foreign languages, the beneficial sides of different media means in language learning process.

KEYWORDS: media, newspaper, book, television, radio, magazine.

\section{INTRODUCTION}

Using different means of Mass Media in foreign language lessons can provide teachers and students with creative and practical ideas. Media gives an opportunity to teachers to meet various needs and interests of the students. They also provide students with a lot of language practices through activities using magazines, radio, TV, movies, books, newspapers, Internet and tasks develop reading, writing, speaking and listening skills. They encourage students to read English in general, both during and after the lesson, elevating extensive reading by giving the students the motivation and confidence to themselves, the. Media "inform, amuse, startle, anger, entertain, thrill, but very seldom leave anyone untouched"[2, 81]. Mass Media can supply with immense information, they inspire students to speak and support them combine listening, reading, talking and writing skills, through different kinds of tasks. A simple example is Power Point Presentations which aid students to speak fluently, to keep eye contact and to organize ideas. Through Media Presentations there is more cooperation and communication among students rather than working with the pages of a book individually.

The importance of Mass Media. Media is very essential because we recognize the world through using its means; we can comprehend the world and also attempt to interchange it. "We live in a world where media are omnipresent. An increasing number of people spend a great deal of time watching television, reading newspapers and magazines, playing records and listening to the radio... The school and the family share the responsibility of preparing the young person living in a world of powerful images, words and sounds"[4, 76]. 
Published: May 30, 2021 | Pages: 125-128

Newspapers. Newspapers can be brought easily to the class in various subjects and courses, especially in literature, language classes, history, geography etc. Some of them possess precious information for these subjects, but we should know how to separate this information. Teachers and students use newspapers according to their purposes in different ways. Newspapers can be used for the culture they carry. The more widely learners read, the greater they understand this culture and its meaning. Newspapers can be also used for depicting changes in the language as and helping students and teachers to keep up pace with these changes. Many newspapers are linguistically new and provide valuable linguistic information. They can be used for the broad variety of text sorts and language styles, rarely found in books. Newspapers are very good source for ESP teachers. They can be used as teaching materials to improve students' language skills. Some newspapers are easily read and easily used. Teachers can design exercises to increase reading comprehension, critical thinking skills, writing skills, grammar skills, vocabulary. The teachers should pay attention to the way how to organize a clear activity using them when they have a lot of newspapers and information [3, 157]. Newspapers are mostly suitable for mixedability classes, depending on the activity, questions. While planning a lesson using a newspaper, the teacher should take into account the paragraph, the density of information, the length of the article, the complexity of the language, the content, the time available and the level of the students' knowledge.

Magazines. There are diverse types of magazines. Students like to read mostly political, scientific, fashion, cultural, entertaining and sport magazines. This interest of the university and high school students should be used by the teachers to modernize their teaching materials and split the sameness of the lesson by utilizing always the textbooks. As with magazines, newspapers are sources for different subjects, cutting pictures and passages related with particular topics. Magazines are sources in language development in giving pictures to encourage verbal or written stories. For instance, they can be used for introducing clothes and colors, means of transport, stimulating picture discussions, short stories and for other materials which cover a topic that may be under discussion in a language lesson. In terms of how to use magazines in the classroom we can refer to the ideas and keywords given for the newspapers.

Books. "Books are crucial in modern life as well, a driving force in education, business, law, science, medicine and entertainment. Through books the students gain the legacy of knowledge earned by those who came before" $[1,57]$. Different aged people find information, relaxation, 
Published: May 30, 2021 | Pages: 125-128

pleasure, and inspiration while reading books. Books do not have the immediacy of other Mass Media, but they make up for that by greater punctuality and constancy. Books are preserved in great public libraries or in personal collections. Readers can go back to famous books by rereading them again and again. Others enjoy a book once and pass it on because of wanting others to share their discoveries. "Those who have already discovered the joy of books, however, are hooked for life. And as others become aware of the vast array of books available, they too will find that unrivaled knowledge and pleasure await them between the covers of books" [1,93]. There is a large area that books cover. Besides them there are lots of books that we read as a class assignment, a novel in the English class, in the course English through Prose and Poetry, in British and American literature course; a book on the planets in the science class, and others. Books are the most bearing of the Mass Media. Some people keep books for years, and libraries save them even for centuries. Here is the right place to mention the words of Franklin Roosevelt: "People die, books never die".

Radio. Radio has an important share in creating pictures in the mind through the power of words, in developing people's imagination, it encourages the imagination to fill in the visuals. The listeners can see the drama in their minds. Thus, when radio is used in the classroom it aids students to voice their creativity, to develop their imagination. Radio programs help to learn a language. Radio not only gives new information and entertainment, in language classes it helps the pronunciation, the intonation, the pitch of voice. Students gain a feeling of satisfaction from having understood something of a real podcast and we can see the joy in their faces. They can develop great confidence in their ability to cope with English as it's spoken out of the classroom. Students can use BBC World Service news bulletin, Voice of America and other foreign radio stations. In such cases students have no possibilities, the teacher can record the news bulletin, transcribe it and prepare to explain any difficult vocabulary that may come out.

Television. Television programs can be used as warming-up activities, pre-activities for the issue, as a supplementary material for a certain topic, for up-to-date information, to update the information in the textbooks. Documentaries on Civil War, on Wildlife, on Discovery Channel, and others, have opened valuable windows for the students. Through these documentaries students learn about cultures, languages, science and others. Some of these documentaries, if carefully selected can be used efficiently in the classrooms and be a part of the curriculum. They help students for better understanding of the subject. As we cannot use TV information when it is 
Published: May 30, 2021 | Pages: 125-128

given, we can bring this information into the classroom by videotaping different TV programs for later use.

\section{CONCLUSION}

Mass Media helps teachers make teaching and learning visual. A picture tells a thousand words and it helps students develop their thinking and observation skills, it promotes imagination. Media helps with several issues such as: motivation, editing, recycling, drafting, clarity, revising, mixed-ability classes, variety, updating information in the book, giving life and color to lesson procedures and methods, thus at the same time helping the students improve fluency and accuracy.

\section{REFERENCES}

1. Beckert Christine, Getting Started in Mass Media, National Textbook Company, Chicago, IL, 1992. -216 p.

2. Biagi Shirley, Media Reader, Wadsworth, New York, 1996. - 190 p.

3. Sanderson Using Newspapers in the Classroom, Cambridge: Cambridge University Press, 1999. -265 p.

4. UNESCO Declaration of Media Education, Grunwald, FRG, 1982. 


\title{
THE IMPORTANCE AND ROLE OF ONLINE COURSES IN THE TRAINING SYSTEM
}

\author{
Abbosjon Soyibnazarov \\ Lecturer Fergana Regional Territorial Center for Retraining and Advanced Training of Public \\ Educators Uzbekistan \\ E-Mail: soyibnazarov115@gmail.com
}

ABSTRACT: This article discusses modern teaching methods and tools that will make school teachers' lessons in the public education system more interesting and high-quality. It also explains to school teachers about the interactive methods needed to teach the teaching process, the development of teaching skills. Nowadays, it is important to keep students interested in the lesson. The organization of the teaching process using modern methods is the same for today's educators, because the more interesting the lesson, the higher the student's knowledge and memory.

KEYWORDS: methodology, ICT, cluster, forums, chats, blogs, open certification, tutor.

\section{INTRODUCTION}

OOTC (Open online training course) is a promising technology for distance learning, which is already being put into practice. OOTC includes open source online training materials. Of course, this information can also be used for classroom lessons. The speech component is often presented in video format, less audio or text format. The system of assessment of student independent work in OOTCs is weak. Many OOTC authors offer students only tests that automatically evaluate the final results and projects that are evaluated by other students (from essays to analysis of firm strategy). This method is called cross-checking. At the same time, the use of cross-checking allows to solve the problem of checking the detailed answers of a large number of students.

OOTCs certainly have many important positive features. They are focused on shaping learning ability, continuing education, and they are implementing a modern model of 'lifelong learning. Flexible organization of lessons during the lessons (the lesson itself, the topic of independent work, the ability to choose the method of completing assignments) allows each student to move in their own direction of study, following a certain time interval. The use of 
Published: May 30, 2021 | Pages: 129-132

modern educational technologies in the construction of courses (extensive use of ICT, the use of methods of developing critical thinking, focus on project technology, etc.) directs the learning process personally and actively, the student becomes a truly active subject of the learning process. Students have the opportunity to get the opportunity to get a modern education, to learn from the best teachers of the world's leading universities. Foreign language courses help them develop informally. A student portfolio will be formed (the completed assignments themselves, reviews and comments on them will be stored), and in the future it will be possible to provide the next scientific and educational trajectory and employment.

\section{THE MAIN FINDINGS AND RESULTS}

Various educational institutions of the world, including the largest universities, are involved in the formation of OOTC communities. The most featured Coursera in the OOTC spectrum. It sells itself as an education company offering free online courses for everyone. Coursera partners are more than 100 leading universities and organizations around the world that have the ability to educate millions of listeners thanks to special technologies.

Suggested topics for study include: game theory, probability models, cryptography, algorithm design and analysis, software as a service, information theory, computer security, sociology, and e-learning problems. All courses are divided into 20 categories, including biology, economics, mathematics, computer science and more. Each subject has its own duration, but the structure of the material is similar for everyone: a series of 80-minute lectures, weekly tests, practical assignments, and a final exam. You can always find additional materials for advanced training. There is a forum where you can chat with other listeners. The principles of placement of course materials and their presentation, of course, depends on the teachers and the capabilities of a particular educational institution.

With the modern development of distance technologies, the quality of the educational process at the university depends on the specific role of the teacher and his ability to creatively use the methods, forms and technologies developed by pedagogical science for a long time. A teacher's willingness to acquire knowledge, to go beyond the boundaries of his or her field of study, and to use interdisciplinary connections is appropriate for this rapidly changing world.

OOTC models are very suitable in the context of in-service training of university teachers as a separate program module and as a separate optional course. These courses, which are the "high point" of modern network learning, can contribute to the formation of professional 
Published: May 30, 2021 | Pages: 129-132

networking communities within the university, as well as to the expansion of international contacts of university teachers.

Online courses are available for free. Teachers wishing to obtain an official certificate of continuing education must pay according to the number of academic hours attended. Currently, public open online courses are in great demand in the teacher training system. Their use allows the teacher to "assimilate" into the modern information-educational environment, to reconsider their position in the learning process in other positions and, in the most optimal case, the organization of their professional activities.

There are almost no real mass online courses to improve the skills of teachers, but in March 2015, the first courses for education managers appeared on the Universarium platform.

The course "Project Management in Education" is aimed at raising the level of professionalism and the formation of competencies that allow to perform project-oriented work functions, as well as to manage and participate in the management of educational projects, to achieve project results. The course is dedicated to describing and analyzing the processes of initiating, planning, and managing educational activities for teachers, administrators, and leaders in modern education systems. An algorithm for forming a set of powers of the project manager is presented.

\section{CONCLUSION}

Thus, public open online courses provide a wide range of people with the opportunity to study various subjects for free and at a distance, and demonstrate a strong global trend in modern education. They are aimed at the active use of all network and mobile services, ie the extensive use of modern information technology. And at the same time, they are a challenge for traditional education, encouraging it to develop innovatively.

\section{REFERENCES}

1. Kostyuk Yu. L., Levin IS, Fuchs AL, Fuchs IL, Yankovskaya AE Massive open online courses - a modern concept in the field of education and training // Bulletin of Tomsk State University. Management, computer technology and informatics. 2014. No. 1. S. 89-98.

2. Cursera. URL: https: //www.coursera.org

3. Bugaychuk KL Massive open distance courses: history, typology, prospects // Higher education in Russia. 2013. № 3. S. 148-155. 
Published: May 30, 2021 | Pages: 129-132

4. Lecture hall. URL: https: //www.lektorium.tv

5. Universarium. URL: https: //universarium.org

6. Foxford Online Learning Center. URL: http: //foxford.ru/

7. Yakovenko TV Distance learning as one of the forms of professional self-development of a teacher // Actual problems of humanities and natural sciences. 2012. No. 3. S. 247-249. 


\title{
SINGLE-GRINDING DIFFRACTOMETER FOR ACTINIC RADIATION EXTREMELY SHORT PULSES
}

\author{
Vincent A. Franco
}

Department Of Applied Science, American University Of Nigeria

\section{ABSTRACT}

A solitary grinding monochromator can be utilized for the ghastly choice of Extremely short beats without modifying in a critical manner the beat term, given that the quantity of enlightened scores is equivalent to the goal. Two designs are analyzed: the traditional diffraction mount (TDM) and the off-plane mount (OPM). The benefits and downsides of the two designs are introduced. The two calculations can be participated in another and imaginative plan of a monochromator with two exchangeable diffracting stages both utilized at touching occurrence, one with the grindings in the TDM and the other in the OPM. The utilization of two phases gives extraordinary adaptability: the OPM stage is utilized for sub-50 fs time reaction and low otherworldly goal and the TDM stage for 100-200 fs time reaction and high phantom goal. The plan beats the constraints of the two single arrangements, giving on a similar instrument either ultrafast reaction with low unearthly goal or more slow reaction with higher goal.

KEYWORDS: diffraction grindings; ultrafast optics; outrageous bright spectroscopy

\section{INTRODUCTION}

Laser beats however short as a couple of femtoseconds seem to be these days accessible for highgoal time-space spectroscopic applications to numerous spaces of science from strong state physical science to science. While optical lasers have offered one of a kind bits of knowledge into super quick femtosecond elements, primary game plan and movement of cores are not straightforwardly available from estimated optical properties. This hole has been filled by the accessibility of cognizant Extremely short sources in the limit bright (XUV) and delicate X-beams, for example, high-request laser music (HHs) and free-electron-lasers (FELs). HHs, which are 
Published: May 30, 2021 | Pages: 133-135

produced through nonlinear connection among iotas and Extremely short laser beats, are tabletop Extremely short sources with high splendor, soundness and pinnacle power. The HH range is portrayed as a grouping of pinnacles comparing to the odd music of the major laser frequency with a power circulation described by a level whose augmentation is identified with the heartbeat force. The mix of the utilization of cutting edge stage coordinating with instruments and cooperation calculations, just as serious ultrafast laser has made it conceivable to acquire $\mathrm{HH}$ radiation up to the water window district $(2.3-4.4 \mathrm{~nm})$. Also, the radiation produced with the plan of the HHs utilizing not many optical-cycles laser beats is these days the fundamental device for the examination of issue with sub-femtosecond goal. The utilization of the XUV outflow in a restricted band requires the ghostly determination of a solitary consonant with a reasonable monochromator that needs to save the worldly length of the XUV beat as short as the time goal needed for the trial.

\section{THE MAIN FINDINGS AND RESULTS}

The grinding effectiveness bends, as coming about because of reproductions, are appeared . For saw-tooth profiles, the effectiveness is relied upon to be hypothetically high in the two designs. In any case, there are profound contrasts between the TDM and the OPM when the real state of the notch profile is examined. Indeed, the exhibitions of blasted grindings in the TDM are fundamentally subject to the real furrow profile. Specifically, the unavoidable smoothing of the sharp edges of the real profile gives a diminishing of effectiveness concerning the hypothetical qualities that is more clear for outrageous blast points, where the acknowledgment of an ideal saw-tooth profile is for all intents and purposes impossible.

\section{CONCLUSION}

The beat front slant of single-grinding diffractometer for XUV Extremely short beats has been dissected. Two diverse grinding arrangements have been looked at: the traditional diffraction mount and the off-plane mount. The two calculations have been participated in an inventive plan of a monochromator with two exchangeable diffracting stages both utilized at brushing rate. The OPM stage is utilized for sub-50 fs time reaction and low phantom goal; the CDM stage for 100- 
Published: May 30, 2021 | Pages: 133-135

$200 \mathrm{fs}$ time reaction and higher otherworldly goal. The plan conquers the restrictions of the two single arrangements, giving extraordinary adaptability on a similar instrument, that is, both ultrafast time reaction with low ghastly goal and longer reaction with higher goal.

\section{REFERENCES}

1. Ramankutty, N.; Foley, J.A. Extremely short Laser Pulse Phenomena, second ed.; Elsevier: London, UK, 2005; pp. 277-394, pp. 531-554.

2. Houghton, R.A. Cognizant Sources of XUV Radiation; Springer: New York, NY, USA, 2006; pp. 277-344.

3. Hayes, D.J.; Babcock, B.A.; Yu, T.; Dong, F. Age of intelligible delicate X beams at $2.7 \mathrm{~nm}$ utilizing high sounds. Phys. Fire up. Lett. 1998, 79, 2967-2971.

4. Tokgoz, S.; Elobeid, A.; Fabiosa, J.F.Age of cognizant X-beams in the water-window utilizing 5-femtosecond laser beat. Science1998, 278, 661-664. 5.Corkum, P.B.; Kammen, D.M. Attosecond science. Nat. Phys.2008, 3, 381-386.

6. Farrell, A.E.; Plevin, R.J.; Jones, A.D. High-energy attosecond light sources. Nat. Photonics 2012, $5,655-662$. 


\title{
PILLAR CAPTION FROM GWALIOR; A STUDY
}

\author{
F.R. Rehman \\ Department Of History \\ Rashtrasant Tukadoji Maharaj Nagpur University India
}

\section{ABSTRACT}

Epigraphy is a significant part of verifiable archaic exploration. It gives substantial realities, yet in addition reveals insight into different parts of antiquated Indian history-be it political, social, strict or social. In this article an endeavor has been made to examine and break down engravings engraved on two bits of pillars which have been recuperated from a cutting edge asphalt in the Gwalior fortification and now saved in the Gujari Mahal Archaeological Museum of Gwalior. It is in proto-Nāgarī script having 22 refrains in Sanskrit language. Pillars were essential for a sanctuary maṇdapa. A basic investigation of the pillar engraving arranges it in the last $50 \%$ of the 10th century C.E. both based on palaeography just as on inner substance.

KEYWORDS: Engraving, Proto-Nāgarī, Gurjara-Pratihāra, Gwalior, Maṇḍapa, Kanauji, Gopādri

\section{INTRODUCTION:}

The engraving being talked about is engraved on the upper pillars of the mandapa of a sanctuary. Just two bits of the pillars bearing engravings have been recuperated so distant from a cutting edge asphalt in the Gwalior fortification and now protected in the Gujari Mahal Archaeological Museum of Gwalior. It was accounted for by M. B. Garde in Annual Report of the Archeological Department Gwalior State for V.S. 1984/C.E. 1927-28, no. 43-44. Harihar Nivās Dvivedī gives practically a similar portrayal in Hindi in Gwālior Rājya kē Abhilekha, no. 618. In Annual Report of Indian Epigraphy for 1952-53, no. B 143 just the reference of Garde is given and Michael D. Willis gives brief data in Caption of Gopakșetra, p. 109. The language of the engraving is Sanskrit and the characters are proto-Nāgarī. The engraving comprises 22 Sanskrit refrains and more likely than not been formed by a sharp writer, who was recognizable in alamikāra. His overstated metaphors 
Published: May 30, 2021 | Pages: 136-139

will seem alarming and interesting even to one familiar with the typical kāvya style. The characters are common to the period they had a place. Head-mark is yet to widen for covering the whole letter and foot-characteristic of certain letters are not all around created. Average sign $u$ is meant by normal snare mark just as wedged shape foot-mark; average sign e is appeared by a leftward vertical stroke while average sign simulated intelligence is framed by a blend of leftward vertical stroke and an ornamented top-stroke. Of the two pillars, the word prathameyam is engraved toward the finish of the one pillar engraving connote that the engraving starts with this pillar. Then again, the unexpected finish of the subsequent pillar proposes that this record finishes itself in multiple pillars. Other being not discovered thus the substance of the record stays fragmented. This, however a few bits of both the realized pillars are exhausted so it is unimaginable to expect to give the perusing of the whole parts of these two pillars.

\section{THE MAIN FINDINGS AND RESULTS}

These engravings are vital from the perspective of the historical backdrop of the GurjaraPratihāras just as the historical backdrop of the locale. Curiously the engraving of C.E. 875 notices that 'having noticed the excellencies of Alla, the celebrated Ādivarāha, who wished to vanquish the three universes, designated him to the guardianship of Gopādri'. The essential area of the Gwalior makes a focal point of consideration for Gurjara-Pratihāra rulers. The engraving of C.E. 876 gives helpful data to the nearby organization. It notice that 'Bhojadeva was the ruler, the gatekeeper of the fortification or koțțapāla Alla directed Gopagiri, Tattaka instructed the military and the shipper Vavviyāka, the broker Icchuvāka and different individuals from the leading body of the Savviyāka were overseeing the city'. It is likewise known from different sources that the region was heavily influenced by Vaiśya rulers. The political situation of Gopagiri or Gopādri could be better perceived behind the scenes of the historical backdrop of the area Singh 2007: 54-117.

\section{CONCLUSION}

Gurjara-Pratihāras were incredible rulers, and struck to Gwalior relentlessly, perceiving its extraordinary key and military situation in the contemporary political situation. The 
Published: May 30, 2021 | Pages: 136-139

Vāillabhațțasvāmin sanctuary engraving of C.E. 875 and 876 gives pre-greatness to Gopagiri as a solid community in the adjoining regions, however Gopagiri appears to have remained as a satellite of Kanauj even as it filled the tactical need of controlling the hinterland. The militaries of the Rāșțrakūțas over the span of their northern missions may have gone through the area in the three sided battle for power between the Gurjara-Pratihāras, the Pālas and the Rāṣțrakūțas. For example in C.E. 903, a grisly fight between Rāșțrakūṭas' feudatory, mahāsāmantādhipati Guṇarāja and feudatory of the Gurjara-Pratihāras' Undabhața was battled on the bank of the waterway Madhuveṇi at Terhi in which the koțțapāla Caṇḍiyanna, a mahā-aśvapati, a disciple or devotee of Gunarāja, with others lost their lives [Singh 1994-95: 137-42]. Gwalior stronghold was transformed into a 'koța' or fortification with Alla, child of Vāillabhațța as its koțțapāla who filled in as the maryādādhurya, 'superintendent of walks' intended to deal with the security needs of Gopagiri fortress and its environmental factors in the close or inaccessible areas inside or outside the realm of Gurjara-Pratihāras.

\section{REFERENCES:}

1. Willis, Michael D. 1968. SI-YU-KI. Buddhist Records of the Western World, Delhi.

2. Stein, M. A. 1948. Gwālior Rājya kē Abhilēkha, Banaras, V.S. 2005, no. 617.

3. Epigraphia Indica (EI).

4. Singh. A. K.1964 (Reprint). Corpus Inscriptionum Indicarum (CII), Vol. III (Caption of Early Guptas rulers and their replacements), Varanasi.

5. Misra, R. N. 1929-30. Yearly Report of the Archeological Department Gwalior State (GAR) for V.S. 1985, Gwalior, nos. 43-45. 
Published: May 30, 2021 | Pages: 136-139

6. Meister, Michael W.1984 (Reprint). "The Two Caption of the Vāillabhațțasvāmin sanctuary", Epigraphia Indica (EI), I (1893).

7. Dvivedi, Harihar Nivas 1968 (Reprint). Corpus Inscriptionum Indicarum (CII), Vol. I (Caption of Asoka), Varanasi. 
Published: May 30, 2021 | Pages: 140-143

\title{
ABOUT AZIMKHOJA ESHAN DEVON'S MANUSCRIPT AND HIS STUDY \\ Sarvinoz Azizkhonova \\ PhD Student
}

\section{Alisher Navoi State Museum of Literature of the Academy of Sciences Navoi, Uzbekistan}

\begin{abstract}
This article analyzes about the life and work of the sheikh and poet Azimhoji Eshan, who grew up in the literary environment of Kokand in the history of Uzbek classical literature, one of the followers of Ahmad Yassavi, who lived and worked at the end of the eighteenth - first half of the century. XIX century The manuscript fund of the museum contains brief information about the manuscript of the office "Murad-ul-osikin", kept under number 189. The main theme in his poems is this pand exhortation. The article deals with the interpretation of the themes of the Shari'a, the teachings, the enlightenment and the status of truth, which are the main themes in the poet's poems.
\end{abstract}

KEYWORDS: mysticism, devan, manuscript, genre, wisdom.

\section{INTRODUCTION}

In the history of Uzbek classical literature, artists who grew up in the literary environment of Kokand have a significant place. Among them are those whose lives, works, and scientific and creative heritage have not yet been fully explored. A comprehensive study of the heritage of unexplored manuscripts, identification of sources of their works, comparative analysis, determination of their place in the classical literature are topical issues.

One of the artists whose creative heritage is almost unexplored is Azimkhoja Khokandi, a representative of mystical literature, which is an integral part of Uzbek classical literature. He shook his pen under the pseudonym Azimi. Azimi is one of the most talented Sufi poets, who has left a certain mark in the history of Uzbek mystical literature with his new worldview and a wide range of mystical ideas, and through his poems in the genre of wisdom illuminates religious-mystical, moral-enlightenment ideas through unique artistic colors. 
Published: May 30, 2021 | Pages: 140-143

\section{THE MAIN FINDINGS AND RESULTS}

Azimkhoja Khokandi (Azimi) lived and worked at the end of the XVIII century - the first half of the XIX century. The exact dates of Azimi's birth and death are unknown. The approximate date of birth is $1200 \mathrm{AH}(1785-1786)$ and the year of death is $1263 \mathrm{AH}$ (1847 CE). According to the sources, Azimkhoja Eshan was born in Sarmozor mahalla of Kokand in the Naqshbandi-Khojagon sect in an intellectual-priestly family [6.18]. The fact that he was called Khoja Eshan indicates, to a certain extent, that he was one of the great murshids of his time. There is information that in one of his musas in his divan, he repeatedly stated his religious affiliation and his affiliation with the Naqshbandi sect.

Azimi's father was Kamoliddin Khoja. Azimi Eshan is the grandson of gardener Nizamiddin Khoja, poet Jalali [7] he studied in Bukhara together with When he returned to his homeland, he was the imam of a large mosque in the village of Kal Dushan in Hoqand for 40 years. In the last years of his life he became blind.

According to Pulatjon Kayyumov's book “History of Khokand and its literature”, Azimi was a scientist, a monk, a pious, alert, loving, eloquent and handsome, full-bodied, white-faced, with a large beard, a clean man. From the age of half, he was isolated, a Sufi ul mashrab, an attractive man, and his conversation was virtuous. They did not approach the palace of the khans, did not hold any position other than imamship, had a simple marriage, and had many murids and followers [8.321].

About the life and work of Azimkhoja Khokandi in P.Kayyumov's "Tazkirat ush-shuaro", S.Rafiddinov's “Wisdoms of Azimkhoja Eshan”, O.Juraboev's “On the manuscripts of Azim Khoja Eshan and his office", as well as in the collections related to Ahmad Yassavi, data are given as followers. However, these works still do not fully convey the poet's creative heritage to readers. Therefore, there is a lot of work to be done on the textual study and transformation of Azimi's creative heritage.

Azimkhoja's wisdom is based on didactic issues such as Ahmad Yassavi's wisdom, that is, the ideas of religion and faith, piety and religiosity, the world and the hereafter, heaven and hell, and love. For example, in his proverbs, the poet called on the people to be pious and fair, to make fair decisions in every matter. In Azimi's proverbs, the theme of love and romance is described in a unique way. He considers love for God to be real. 
Published: May 30, 2021 | Pages: 140-143

One of the most complete copies of Azimi's devonishoor collection, kept in the manuscript fund of the Alisher Navoi State Museum of Literature under the number №189, and he كتاب مر اد العاشقين (Book of Lovers) (page 125b)[9]. “Murad-ul-oshiqin” manuscript contains a total of 3970 lines (1985 bytes) of the poet's poems in Uzbek and Persian. Devan contains poems on the theme of wisdom, nat, ghazal, muhammas, musaddas, mustahzod, pand exhortation in the genre of prayer [9.9].

It composed 2317 verses and 94 proverbs in Uzbek. They are divided by genres as follows: hikmats - 28, ghazals - 42, murabbas - 28, musaddas - 12, muhammas - 6, mustahzods - 2. Including munajat - 1, na't - 2, Persian poems consisting of 1652 verses are written in 4 genres: ghazals - 1341 verses, munojat ghazal - 1, na't musaddas - 1, muhammas - 2, mustahzod - 1.

The most active use of the twelve $(4+4+4)$ series of finger poetry system (i.e. twelve syllables repeated in each stanza) in the "Murad ul-oshiqin" devan.

His ghazals, musaddas, and wisdoms, which are included in his divan, deal mainly with the interpretation of topics related to the status of the Shari'a, the Tariqah, the Enlightenment, and the truth. In particular, it is obligatory to perform the acts of faith, salaat, zakat, and hajj, which are the basis of the rules of the Shari'ah, as well as to refrain from forbidden acts and to have good morals, to perform the sunnahs, to repent in the sect, to perform his services in accordance with the guidance of the pir, to recite surahs or supplications from the Qur'an, to be in tajrid and tafrid (solitude and solitude), and in enlightenment, to perish, to accept dervishes, wish for honesty, to be enlightened, to adhere strictly to the rules of the Shari'ah and enlightenment, to leave the world, to understand the mysteries of truth only for the sake of the Hereafter, and finally to be humble in truth, to sing the ideas of distinguishing good from evil, of being meek, of following the path of poverty, of wandering, of hiding secrets, of knowing the rules of Shari'ah, teachings, enlightenment, truth, and striving for the unity of Allah by following them.

\section{CONCLUSION}

In conclusion, it can be said that Azimi's "Murad ul-oshiqin" was copied by different secretaries at different times, and more than a dozen manuscripts of his manuscripts and proverbs have survived. These are in the State Museum of Literature named after Alisher Navoi (under number 189), the main fund of the Institute of Oriental Studies named after Abu Rayhan Beruni (inv. Number: 5992 / II) and the Department of Manuscripts named after Hamid Sulaymon (inv. Number: 2563 / I, 2694, 6354), These are the Devonian manuscripts kept in the 
Published: May 30, 2021 | Pages: 140-143

Kokand Museum of Literature (inv. Number: 6209, 6750, 6806). It is expedient to study these manuscripts in depth, make a comparative analysis and acquaint our people with the content of the works contained in it.

\section{REFERENCES}

1. P.Qayyumov. History of Khokand and its literature. -Tashkent: "Tamaddun”, 2011. -P. 380.

2. O.Juraboev "On the manuscripts of Azim Khoja Eshan and his office". A mirror of literature. Scientific publication №11. -Tashkent:, 2009. -P. 18-22.

3. Zavqi. "Wonderful time”. Poems. -Tashkent:,2003. -P. 56.

4. B.Xasanov. Azimxoja Eshon. “Murad ul-ashiqin”. Devan. -Tashkent:, 2009. -P. 119.

5. Fund of the State Museum of Literature named after Alisher Navoi of the Academy of Sciences of the Republic of Uzbekistan №189 Manuscript.

6. Jo'raboev O. "On the Manuscripts of Azim Khoja Eshan and His Office”. A mirror of literature. Scientific publication №11. -Tashkent:, 2009. P.18.

7. Jaloliddin Khoja - sheikh and poet, died in h.1261 / m.1845 in the village of Qudash near Kokand.

8. P.Qayyumov. History of Khogand and its literature. "Tamaddun.”-Tashkent:, 2011. P.321

9. Manuscripts Fund of the Alisher Navoi State Museum of Literature. №189 Digital Manuscript; P.9. 


\title{
THE CONCEPT OF NATIONAL STATE THINKING SIGNIFICANCE AND CONTENT
}

\author{
Lutfillo Maxamadaliev \\ Student \\ Faculty of History \\ Fergana State University \\ e-mail: alfargoniy.uz@gmail.com
}

ABSTRACT: The article describes the historical stages in the development of national statehood, socio-philosophical and political relations, their motives, mechanisms, in particular, the formation and development of national statehood in the minds of citizens before independence. effects were analyzed.

KEYWORDS: state, thinking, history, statehood, statehood thinking, citizen, consciousness, independence.

\section{INTRODUCTION}

The formation and development of national statehood thinking is one of the most complex general theoretical issues of philosophy. It deals with all the components of philosophy: ontology, epistemology, methodology, logic, axiology, ethics, aesthetics, psychology, and so on. Consequently, its comprehensive socio-philosophical analysis requires a generalization of the criteria for evaluating the principles of a specific approach to the problem in these areas.

Since the issue of the development of national statehood thinking is complex, contradictory, multifaceted and continuous, it can be covered relatively perfectly on the basis of a complex-systematic approach of all socio-political sciences. However, its criteria change in the course of the development of society and are enriched by new requirements.

In particular, first, the process of further deepening democratic reforms in the country is reflected in the national state thinking of citizens, that is, its level of development is the main criterion of national state thinking. 
Published: May 30, 2021 | Pages: 144-148

Second, the formation of national statehood thinking depends on the main reformist activities of the state. That is, the state is the organizer of economic, political, ideological, spiritual and educational activities of citizens in cooperation with the state. Every citizen is interested not only in the existence of the state, but also in its great future.

Third, citizens can effectively participate in the work of rational management only if they have a deep and comprehensive understanding of the nature and essence of the independent state of Uzbekistan. Accordingly, it can be said that the understanding of the essence of the state by every citizen, the struggle for its future is the main content and essence of national statehood thinking. In general, in the socio-philosophical analysis of the development of national state thinking, it is necessary to take into account three important social functions of thinking. First, it reflects the existence of statehood in the national consciousness and expresses it through thinking (language); secondly, provides theoretical and methodological support for its formation and development; third, it creates statehood models and predicts the future.

The idea of national statehood is the existence of a state, its historical development, the harmony of state and civil interests, the pride of citizens in international social, economic, political, spiritual, ideological relations, confidence in the great future, the participation of all in the process of building national statehood. is a set of scientific and practical concepts that embody the creation of the ability and capacity to develop conscious passion. The definition given to the thinking of national statehood expresses its essence and acquires new features based on the content of historical periods of statehood.

\section{THE MAIN FINDINGS AND RESULTS}

"National statehood" and "national statehood thinking", both as a reality and as a scientific concept, do not exclude each other, but require them. However, each of them is a separate reality and differs in its existence, laws of formation, national characteristics. In particular, national statehood is a type of state based on the social, economic, political, spiritual values and interests of a particular nation, formed as a result of the development of the history of society. The formation of a state that protects the interests of different peoples, united in a region, to organize the social life of the majority, is in line with the worldview, traditions, psyche of the nation that formed it. 
Published: May 30, 2021 | Pages: 144-148

Statehood is a historically structured political phenomenon, a form and condition of existence of the social existence of a particular people. Concerning the state, Cicero said, "The state is the wealth of the people, and the people are not a collection of people somehow gathered together, but a community of many people connected by mutual agreement on the common rights and interests." [1] The unification of many people and social strata as a people takes place through an understanding of the generality of the historical development of their statehood thinking. In political theories, national statehood is generally recognized as a classical form of statehood, and it is noted that it plays an important role in the unification, development, and more stable and stable mental characteristics of the nation [2].

The idea of national statehood is stable compared to other historical forms of thinking, but also has the character of sustainable development. Therefore, the thinking of national statehood is the basis for the freedom of thought of members of society, especially the younger generation, free from dogmatism and backwardness, a critical approach to the analyzed events, a creative approach to reality. After all, the idea of national statehood cannot be reconciled with the vices of nationalism and localism. That is why the First President IA Karimov said: "Everyone living in our country should first of all feel like a citizen of Uzbekistan, and only then a representative of a certain region, say, Khorezm, Samarkand or the Fergana Valley. Naturally, this situation does not diminish the value and importance of the "small homeland" to which each of us belongs, the city or village where he was born and grew up. "[3] theoretical, methodological guidelines.

\section{CONCLUSION}

first, the national statehood thinking formed in the minds of citizens serves as a driving force for the development of an active system of relations and the sustainable development of society;

secondly, the conceptual theoretical conclusions and practical policy developed for the re-establishment of the national state system in independent Uzbekistan became the methodological basis for the formation of national statehood in the minds of citizens;

third, the mentality of national statehood calls the citizens of Uzbekistan to renewal and a common goal for the future;

fourth, in the ongoing reforms in the socio-economic spheres, there is no doubt that the thinking of national statehood plays an important subjective factor; 
Published: May 30, 2021 | Pages: 144-148

fifthly, in the minds of every citizen, in his thinking, to develop a sense of pride in his state, to ensure its sustainable development.

\section{REFERENCES}

1. Каримов И. А. Буюк келажак сари. Т.; “Ўзбекистон” 1998. 302 -бет.

2. Цицерон. О государстве // Мухаев Р.Т. Хрестоматия по теории государства ипарва, политологии, истории политеческих и правовых учений. - М.; 2000. С.74.

3. Фалсафа. Қомусий луғат. 263 - бет; Гроций Г. О праве войны и мира.- М.; 1956.С. 74: Локк. Дж. Сочинения в 3-х томах. Т.3. - М. 1956. С.388.; Гоббс Т. Сочинения. Т.2. - М.;1992.С. 133.: Кант И. Сочинения в 6-ти томах. Т.4. - М.; 1965. С.270-383. Исломов 3.М. Давлат ва хуқуқ назарияси. - Т.; 2007, 180 -181-бетлар.

4. Bakhromovich, S. I. (2020). Effects of Objective and Subjective Factors to Develop Intellectual Culture of Youth. Canadian Social Science, 16(2), 55-59.

5. Ahmadjonovna, E. T., \& Bakhromovich, S. I. (2020). Pedagogical Analysis Of CulturoEducational Institutions' Actions In Youth Education (On The Example Of Museum Activities). The American Journal of Social Science and Education Innovations, 2(08), 576-582.

6. Сиддиков, И. Б. (2018). Социально-философские аспекты формирования интеллектуальной культуры молодёжи. Theoretical \& Applied Science, (1), 61-66.

7. Bakhromovich, S. I. (2018). Social and philisophical performance of making youth's intellectual culture. European science review, (7-8).

8. Bakhromovich, S. I. (2020). Analysis Of Modern Approaches To Ensuring The Effectiveness Of Management In Higher Education Institutions. The American Journal of Social Science and Education Innovations, 2(12), 364-369.

9. Siddikov, I., \& Gulomov, A. (2020). Philosophical and psychological features of the formation of asertive behavior in the development of cognitive activity. In Психологическое здоровье населения как важный фактор обеспечения процветания общества (рp. 38-42).4

10. Сиддиков, И. Б. (2019). Государственная политика в отношении молодежи в Узбекистане: национальный опыт и реальная необходимость международных инициатив. In Условия социально-экономического развития общества: история и современность (pр. 38-43). 
Published: May 30, 2021 | Pages: 144-148

11. Bakhromovich, S. I. (2020). The impact of managerial professional development on the effectiveness of Higher Education institution management. Academicia: an international multidisciplinary research journal, 10(12), 1014-1020.

12. Siddikov, І. В. (2019). Философско-педагогические аспекты развития интеллектуальной культуры студентов. Вестник Ошского государственного университета, (3), 38-42.

13. Bakhromovich, S. I. Development trends and transformation processes in academic mobility in higher education in Uzbekistan and the world.

14. Mirzarahimov, B. H. (2020). The Tasks Of Tourism In Aesthetic Education: The Harmony Of Historicity And Modernity. The American Journal of Social Science and Education Innovations, 2(09), 652-658.

15. Mirzarahimov, B. (2019). The factor of good neighborhood and tourism development (Philosophical analysis). Scientific Bulletin of Namangan State University, 1(1), 140-145.

16. Mirzarakhimov, B. (2020). Tourism-is a modern means of aesthetic education. BecmHuk педагогики: наука и практика, (51), 135-136.

17. Мирзарахимов, Б. Х. (2019). Культура туризма как стратегия развития книговедения. in перспективные области развития науки и технологий (рр. 57-58).

18. Madimarovna, A. I., \& Khoshimovich, M. B. (2020). Factors for the development of tourism culture in the uzbek national value system. ACADEMICIA: An International Multidisciplinary Research Journal, 10(4), 575-580. 


\title{
THE LEVEL OF FEELING OF HAPPINESS AMONG NURSES STUDYING AT THE DEPARTMENT "NURSE WITH HIGHER EDUCATION" AT THE CENTER FOR ADVANCED TRAINING OF MEDICAL WORKERS
}

\author{
Rikhsi Kamilovna Solikhodzhaeva \\ Ph.D., Associate Professor \\ Department of "Nurses with Higher Education" of the Center for Advanced Training of Medical \\ Workers " Uzbekistan \\ Jamilakhon Erkinovna Kamilova
}

Assistant

Department of "Nurses with higher education" of the Center for Advanced Studies of Medical Workers Uzbekistan

\begin{abstract}
The article examines the level of happiness among nurses studying at the Department of Nursing with Higher Education at the Center for Advanced Training of Medical Workers.
\end{abstract}

KEY WORDS: happiness, learning, Oxford Happiness Questionnaire.

\section{INTRODUCTION}

For a person at all times it has been and will be important to feel happy. For each person, the feeling of happiness is different. For some, happiness lies in health, for others - in prosperity, the presence of a certain prosperity, while others see happiness in each new day: in the opportunity to get up every morning, see the peaceful sky overhead, breathe and taste the joys of life.

At the present stage of development of society, the requirements for each of its members are increasing. "Happiness and life satisfaction have a significant impact on how people behave in difficult life situations and affect the choice of strategies and specific ways to overcome them." Happiness is a state for which everyone should prepare, grow it and keep it within themselves. 
Published: May 30, 2021 | Pages: 149-152

People who have learned to control their experiences will be able to influence the quality of their lives themselves. This is the only way each of us can come closer to being happy.

Research is currently underway on the relationship between health and happiness. The objects of these studies are precisely the relationship between things that are directly associated with each other, but not necessarily have a cause-and-effect relationship. Indicators of happiness include life satisfaction, health, environment, and role in society. We tried to determine the level of feeling of happiness among the nurses of the department "Nurse with higher education" at the Center for Advanced Training of Medical Workers and some of the factors affecting this level.

The study involved 80 mid-level health workers. The respondents were comparable in age and gender: $80 \%$ were women, $20 \%$ were men. The average age of the subjects was 34 years. The Oxford Happiness Questionnaire was used to assess the level of happiness.

To identify somatic complaints, the Giessen somatic complaint questionnaire was used. To assess the stress resistance of the nurses, the stress resistance test was used by Yu.V. Shcherbatykh. Taking into account the level of happiness, all surveyed nurses were divided into 2 groups: group 1 included nurses with an average level of happiness; in the 2nd group - with a reduced level of happiness.

\section{THE MAIN FINDINGS AND RESULTS}

According to the criteria for evaluating the results of this technique, the average level of happiness is in the range from 41-60 points; the reduced level of happiness is in the range of 21-40 points. The level of happiness in-group 1 was $54.7 \pm 1.1$ points; the indicator in-group 2 was $40.3 \pm 0.8$. There was revealed a significant difference in the indicator of the level of happiness in the groups: $p<0.05$. Taking into account the indicator of the level of happiness in these groups using the Giessen questionnaire, which includes the characteristics of complaints about physical well-being, the subjective level of feeling of well-being and its intensity were determined.

The scores for the first four scales are in the range of 0-24, for the fifth, in the range of o96 points. According to the criteria for evaluating the results of this technique, all indicators are normal. The scale of "nervous exhaustion" characterizes the nonspecific factor of sensation, which indicates a general loss of vital energy, a person's need for help. This indicator was higher 
Published: May 30, 2021 | Pages: 149-152

for nurses with a reduced level of happiness and amounted to $5.9 \pm 0.7$ points, while for students with an average level of happiness it was $4.1 \pm 1.3$ points.

The Stomach Complaints scale reflects the syndrome of nervous (psychosomatic) gastric ailments (epigastric syndrome). Revealed significant differences between the groups. This indicator was significantly higher in nurses with a reduced level of happiness and amounted to $2.4 \pm 0.5$ points; $p<0.05$. For nurses with an average level of happiness $-0.7 \pm 0.3$ points. The Pain Complaints scale expresses subjective suffering of a spastic nature. Revealed significant differences between the groups. It was revealed that most often complaints were noted on the scale of "Stomach complaints" and "Painful complaints", somewhat less often, there were complaints of the heart and on the scale "Nervous exhaustion".

Nurses with reduced levels of happiness had significantly lower levels of stress tolerance. In the course of the study, it was found that according to the criteria of this technique, the value of the baseline indicator in the range from 70 to 100 points could be considered satisfactory. For cadets with an average level of happiness, this indicator was $71.3 \pm 9.2$ points. For cadets with a reduced level of happiness, this is an indicator of $87.6 \pm 4.1$ points. Dynamic stress sensitivity measures the ability to resist stress through appropriate behavior.

Average scores range from 12 to 28 points. This indicator in cadets with an average level of happiness was below the norm and amounted to $11.5 \pm 1.8$ points, and in cadets with a reduced level of happiness, it was below the norm and amounted to $17.6 \pm 1.4$ points.

The largest number of cadets note the following methods of stress relief: sleep, rest and communication with friends or a loved one.

\section{CONCLUSION}

Thus, the study made it possible to formulate the following conclusions:

1. $25 \%$ of nurses ( $70 \%$ of women, $30 \%$ of men) felt an average level of happiness and $75 \%$ had a reduced level of this indicator. 
Published: May 30, 2021 | Pages: 149-152

2. In cadets with an average level of happiness, the indices of intensity of complaints about physical well-being are significantly lower than in cadets with a reduced level of happiness.

3. Cadets with an average level of happiness were less sensitive to stress; reacted less to circumstances that could not be influenced; were less inclined to unnecessarily complicate the situation; had a lower predisposition to mental illness than Cadets with a reduced level of happiness had.

\section{REFERENCES}

Kaplan G., Sadok B. Clinical psychology, translated from English. Supplemented / ed. Dmitrieva T.B. - M .: GEOTAR Medicine, 1998.-505 p.

Karvasarsky B.D. Neuroses and psychosomatics. - M .: Medicine, 1990. - 576 p.

Sidorov P.I., Parnyakov A.V. Clinical psychology: textbook. - 3rd ed., Rev. and add. - M .: GEOTARMedia, 2008 .-- 880 p.

Lebedeva N.M., Ivanova E.A. Journey to Gestalt: theory and practice - SPb. Rech, 2004. - 560 p.

Tregubov IB, Babin SM, Giessen questionnaire of somatic complaints. - SPb: 1992 .- 23 p. 


\section{DĪWĀN LUGHĀT AL-TURK - UNIQUE ENCYCLOPEDIC HERITAGE}

\section{Z.I. Sattorova \\ PhD Student}

\section{Tashkent State University of Oriental Studies}

\section{Tashkent, Uzbekistan}

ABSTRACT: This article discusses the fact that Mahmud Kashgari also completed his book "Diwan lugat at turk" in 1075, which he had created for many years. In other words, Kashgari is an encyclopedic scholar, and Diwan is an encyclopedic intellectual product of the Renaissance. During his lifetime, the Samanids were replaced by the Qarakhanid dynasty in Movarounnahr, and the Turkic literary language became a widespread tradition in the region.

KEYWORDS: "Diwan lugat at turk”, Diwan, Kashgari, encyclopedic scholar, intellectual product, Renaissance, Samanids, Qarakhanid dynasty, Movarounnahr, Turkic literary, language, widespread tradition, region.

\section{INTRODUCTION}

Mahmud Kashgari is one of the brightest representatives of the Renaissance in the Karakhanid state. Based on the study of a wide variety of materials collected in his Diwan lugat at turk, most scholars consider him to be one of the greatest contributors to the development of linguistics, literature, history, ethnology, geography and other fields of science. In other words, Kashgari is an encyclopedic scholar, and Diwan is an encyclopedic intellectual product of the Renaissance [1.12-15]. He raised the humanistic knowledge of the Middle East to a higher level. At a time when his predecessors were studying the grammar of Arabic, the language of the Qur'an and science at the time, Mahmud Kashgari was one of the first to be the object of his research, despite the fact that Turkish was only the language of everyday life of the Turkic peoples.

\section{THE MAIN FINDINGS AND RESULTS}

Diwan lugat-at-turk for the first time presented a vocabulary of Turkic languages, so we have the right to call the work a dictionary [2.15]. Mahmud's father's name was Husayn, and his 
Published: May 30, 2021 | Pages: 153-156

grandfather's was Muhammad, and he was of Kashgari descent according to his origin and language. During his lifetime, the Samanids were replaced by the Qarakhanid dynasty in Movarounnahr, and the Turkic literary language became a widespread tradition in the region. Even in the centers of the Abbasid caliphate, in the lands inhabited by Arabs and other Samanids, the number of Turkic peoples increased and the Turkic language became more important. Mahmud Kashgari also completed his book "Diwan lugat-at-turk" in 1075. The main text of the work was written in Arabic, which at that time was the language of religion and science in the Muslim East, the whole Middle East, and was written to explain the richness, meaning and diversity of the Turkic language.

One of the most important and comprehensive works on the devon in recent years has been the research of well-known Turkish scholars Ahmet Bijam Erjilasun and Ziyat Akkoyunli [3.1120]. (Dr. A.B. Erjilasun has published 20 books and about 80 scientific articles on the study of the Diwan. Also, more than 30 scientific publications of Dr. Ziyat Akkayunlin have been devoted to the study of the "Diwan lugat-at-turk" [4.260-276]) An important aspect of the study was the history of the author, writing and survival, title, text interpretation, transcription, and most importantly, the errors in publications and translations, which were compared with the manuscript. In this regard, in 2019, an article by Dr. F. Ersoy, a student of A. B. Erjilasun, entitled "I was caught in a book". According to the article, the scientist wrote a didactic work entitled "Dewan lugat-at-turk" [5.173]. What surprised the scholar was that during the publication of the book “Kashgarli Mahmud - Diwan Lugat at-Turk (Introduction - Text - Conversion - Notes Directory)" by AB Erjilasun and Z. Akkayunli, he had the opportunity to get acquainted with the work and read it. He chooses the representatives of two periods as heroes of the novel, that is, Ali Amir, who lived in Istanbul in 1912, and the works of two Turkologists as modern heroes. In the novel, the author describes the discovery of the diwan and the myths and facts associated with it [6.87-88].

The name of Ali Amir opened a new history of the "Diwan Lugat at-Turk". In 1913, Amir Sahib, a fan of ancient and unique books in Istanbul, bought the devon from Burhanbey without fully realizing its value. The worn-out book is brought to Burhanbey by a woman who is a relative of former Finance Minister Ahmed Nazif Pasha. Before his death, the former minister, who died in 1905, had given the woman a book and bequeathed it not to sell for less than 30 liras even when she was in dire need. Research on how the book fell into the hands of Nazif 
Published: May 30, 2021 | Pages: 153-156

Pasha showed the name was added to the first page after the diwan was copied by Abu Bakr Savi Damascus [7.8] one of the owners of the book passed to the Egyptian Muhammad Khatib Daraya. The Turkish Sultan Yavuz Sultan Selim, who conquered Egypt, sent all the booty - riches and treasures, unique material and spiritual resources by water to the Topkapi Palace. Devon thus came to Turkey from Egypt. Given that Nazif Pasha's ancestors ruled the palace for many years, the predictions about the fate of the diwan are closer to reality.

\section{CONCLUSION}

In conclusion, the only copy of "Diwan Lugat at-Turk"is kept in the Istanbul (Fatih) National Library under number 4189. The manuscript was copied from the original in Damascus by Muhammad Abu Bakr al-Savi in $664 \mathrm{AH}$, on the 27th of Shawwal (August 1, 1266). It measures $23.9 \times 16.5 \mathrm{~cm}$ and consists of 319 pages on thick oriental paper. The manuscript is written in black and red ink in Naskh script. Poygir, no page numbers. Pages 11b-12a include a map drawn by Kashgari with his own hands and called a "circle". The clear and well-written spelling of the Arabic and somewhat intricate Uyghur letters is a testament to the calligrapher's skillful writing of his time. The manuscript is 319 pages long, 17 pages per page.

\section{REFERENCES}

1. Aliev. A Mahmud Kashgari is an encyclopedic scientist of the Renaissance period in the Karakhanid state. A. Aliev Bulletin of KRSU. 2015. Volume 15. №10/ P. 12-15.

2. Mahmud al-Kashgari. Diwan lugat at-Turk (Code of Turkic words). In 3 volumes. Tashkent:, A.R. Rustamov, ed. IV Kormushina [Text] / Mahmud al-Kashgar. - Moscow: 2010. - P.15.

3. Ercilasun, A. B., Akkoyunlu, Z. (2014). Kashgarli Mahmud Divanu Lugati't-Türk (Introduction Text - Translation - Notes - Index), Ankara: TDK Publications. P.1120

4. Tamir N. Prof. Dr. Ahmet Bican Ercilasun ve Prof. Dr. On the judicial work Diwan lugat at-Turk prepared by Ziyat Akkoyunlu. International Journal of Turkish Literature Culture Education Issue: 3/3 2014 P. 260-276, Turkey:

5. Ersoy, Feyzi. (2019). “I’m stuck with a book! Roman Diwanu Lugati at-Turk Ankara: Gazi Yai Bookstore. P. 173.

6. Erkan Karagoz . I'm stuck with a Book. Turkish Dormitory. Number 380. Nisan. 2019. P. 87-88 
Published: May 30, 2021 | Pages: 153-156

7. Dankoff, Robert, [with James Kelly] (1985), Mahmud al- Kashgari, Compendium of the Turkic Dialects ( Diwan Lugat at- Turk), edited and translated with introduction and indices. Cambridge, Mass.., Part I: 1982. P.8

8. Sattorova, Z. I. (2020). ANALYSIS OF MAHMUD AL-KASHGARI SONGS IN “DIWAN LUGHAT AL-TURK”. In WORLD SCIENCE: PROBLEMS AND INNOVATIONS (pp. 105-109).

9. Sattorova, Z. I. (2020). ON THE POETICS OF LYRICAL SONGS IN DIWAN LUGHAT AL-TURK. In SCIENCE INNOVATIONS (pp. 22-27).

10. Ismoilovna, S. Z. (2020). Ideological interpretation of seasonal and ceremonial songs in "Diwanlughat al-turk"-“Compendium of the languages of the turks". Asian Journal of Multidimensional Research (AJMR), 9(6), 165-171. 


\title{
FEATURES OF CLINICAL PARAMETERS IN PATIENTS WITH ISCHEMIC STROKE WHO UNDERWENT COVID-19
}

\author{
M.T. Yuldasheva \\ Tashkent Pediatric Medical Institute Tashkent, Uzbekistan
}

ABSTRACT: According to experts, cardiovascular diseases (CVD) are one of the key risk factors for severe course and serious complications in case of infection with coronavirus: a previous stroke increases the risk of resuscitation and mechanical ventilation by 2.5 times. CVD is the most common comorbidity in coronavirus infection: it occurs in 1/3 of patients with COVID-19, increases the risk of hospitalization by 6 times and the risk of death by 12 times. In $67 \%$ of patients with concomitant diseases who died from COVID, they suffered from heart and vascular problems (1, $2,3)$.

KEYWORDS: experts, cardiovascular diseases, risk factors, severe course, serious complications, infection, coronavirus, previous stroke, resuscitation, mechanical ventilation, comorbidity, hospitalization, concomitant, heart problems, vascular problems.

\section{INTRODUCTION}

We examined 280 patients with a history of ischemic stroke who had undergone COVID-19 (mean age $53.9 \pm 8.1$ years; gender index 1.37: 1.0 (162 men and 118 women each). A clinical examination method, pulse oximetry, visual analogue scale of headache (VAS) were used, the intensity of Asthenia was assessed on a five-point scale in points. The severity of the main clinical symptoms (shortness of breath, cough) was assessed according to the developed point scale from 0 to 3 points. In this section, statistical material is presented as arithmetic mean + standard deviation $(M+\sigma)$. To assess the reliability of the difference in percentages, Fisher's angular transformation criterion was used.

\section{THE MAIN FINDINGS AND RESULTS}

Symptoms of patients who underwent COVID-19 at the onset of the disease were characterized by a subacute onset with a temperature reaction in all patients from subfebrile numbers to severe fever. According to many authors, among the first symptoms of COVID-19, an increase in body temperature was recorded in $90 \%$ of cases [2]. 
INNOVATIVE DEVELOPMENT DISCOURSE MODERN SCIENCE AND EDUCATION

Published: May 30, 2021 | Pages: 157-163

The average temperature on admission was $38.1 \pm 0.90 \mathrm{C}$ in men; in women, it was slightly higher $-38.9 \pm 1.20 \mathrm{C}$. According to the data in table 1 catarrhal syndromes and gastroenteritis in general were rare, but in women these symptoms were detected significantly more often than in men.

This disease is characterized by a subacute course, although in women in $22.9 \%$ of cases there was an acute course - with a sharp rise in temperature and symptoms of intoxication.

Headache and general weakness are an obligatory condition of the new coronavirus infection [3]. Our data also showed that headache was in $85 \%$ of cases in all examined patients; in the study of this syndrome, depending on gender, it was found that women more often complained of headache, in contrast to men $-94.9 \%$ and $71.0 \%$ respectively.

An increase in pulse and respiratory movements was recorded in all the subjects; there were no significant intergender differences in these indicators.

Table 1

Symptomatic picture of patients

\begin{tabular}{|c|c|c|c|}
\hline \multicolumn{2}{|c|}{ Symptoms of defeat } & \multirow{2}{*}{$\begin{array}{r}\text { Men, } n=162 \\
38,1 \pm 0,9\end{array}$} & \multirow{2}{*}{$\begin{array}{c}\text { Women, } \mathrm{n}=118 \\
38,9 \pm 1,2\end{array}$} \\
\hline $\begin{array}{l}\text { General infectious } \\
\text { symptoms }\end{array}$ & $\begin{array}{l}\mathbf{r}^{\circ} \mathrm{C} \text { on admission } \\
\mathbf{M} \pm \mathbf{v})\end{array}$ & & \\
\hline & $\begin{array}{l}\text { Cattarhal syndrome } \\
(\mathbf{n} \%)\end{array}$ & $39 / 24,1 \%$ & $42 / 35,6 \%$ \\
\hline & Gastroentiritis $(n / \%)$ & $2616,0 \%$ & $38 / 32,2 \% *$ \\
\hline \multirow[t]{2}{*}{ Flow } & Spicy $(\mathbf{n} / \%)$ & $14 / 8,6 \%$ & $20 / 169 \% *$ \\
\hline & Subacute (n/\%) & $148191,4 \%$ & $98 / 83,1 \% *$ \\
\hline \multirow[t]{2}{*}{$\begin{array}{l}\text { General celebral } \\
\text { symptoms }\end{array}$} & Headache $(n / \%)$ & $115 / 71,0 \%$ & $112 / 94,9 \% *$ \\
\hline & Weakness $(n / \%)$ & $125 / 77,2 \%$ & $11294,9 \% *$ \\
\hline \multirow{4}{*}{$\begin{array}{l}\text { The state of } \\
\text { respiratory and } \\
\text { cardiovascular } \\
\text { system }\end{array}$} & $R R$ in 1 min $(M+\sigma)$ & $23,7 \pm 1,4$ & $23,3 \pm 1,8$ \\
\hline & $\begin{array}{l}\text { Systolic pressure } \\
(\mathbf{M}(\mathbf{\sigma})\end{array}$ & $122,5 \pm 11,7$ & $98,6 \pm 12,3$ \\
\hline & $\begin{array}{l}\text { Diastolic pressure } \\
\text { (Mto) }\end{array}$ & $74,2 \pm 8,9$ & $61,4 \pm 9,5$ \\
\hline & $R \sin 1 \mathrm{~m} \quad(M \pm \sigma)$ & $77,3 \pm 127$ & $76,9 \pm 10,2$ \\
\hline
\end{tabular}

Note: hereinafter * - reliability of differences, $p<0.005$. 
Published: May 30, 2021 | Pages: 157-163

All patients had symptoms of intoxication, so diffuse headache was characterized as "pressing” in 221 (78.9\%), "bursting" in $21.9 \%$ of patients. (\% was calculated from the total number of studied patients, if the total indicator is considered, if the indicator is considered within a group, then\% is calculated in relation to the number of patients in the corresponding group). Figure 1 shows the intensity of headache in points according to VAS in men and women.

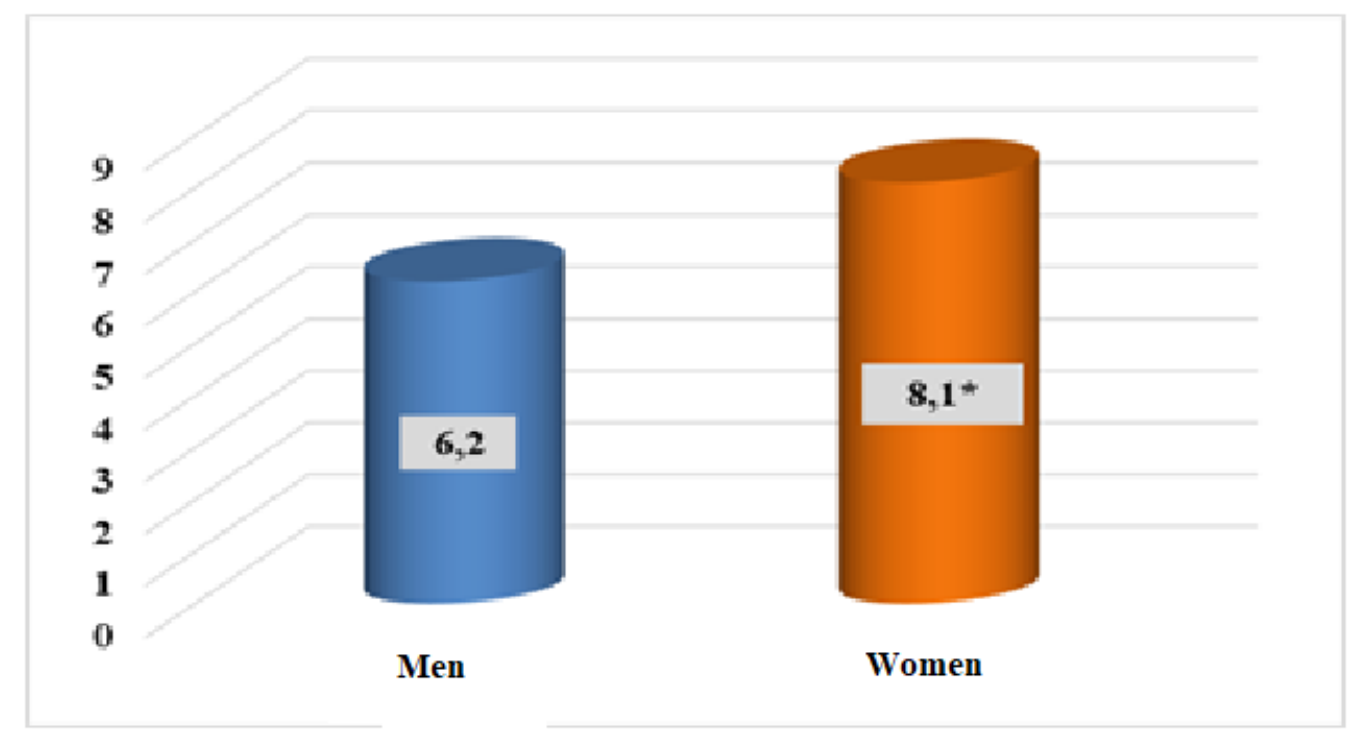

Figure 1 the intensity of the Headache in points according to the VAS

$(*$ - reliability of differences, $\mathrm{p}<0.005)$

Asthenic syndrome was detected in all examined patients in the form of severe weakness. Figure 2 shows the severity of asthenic syndrome in points ( 0 - no asthenia, 5 - severe asthenia). 


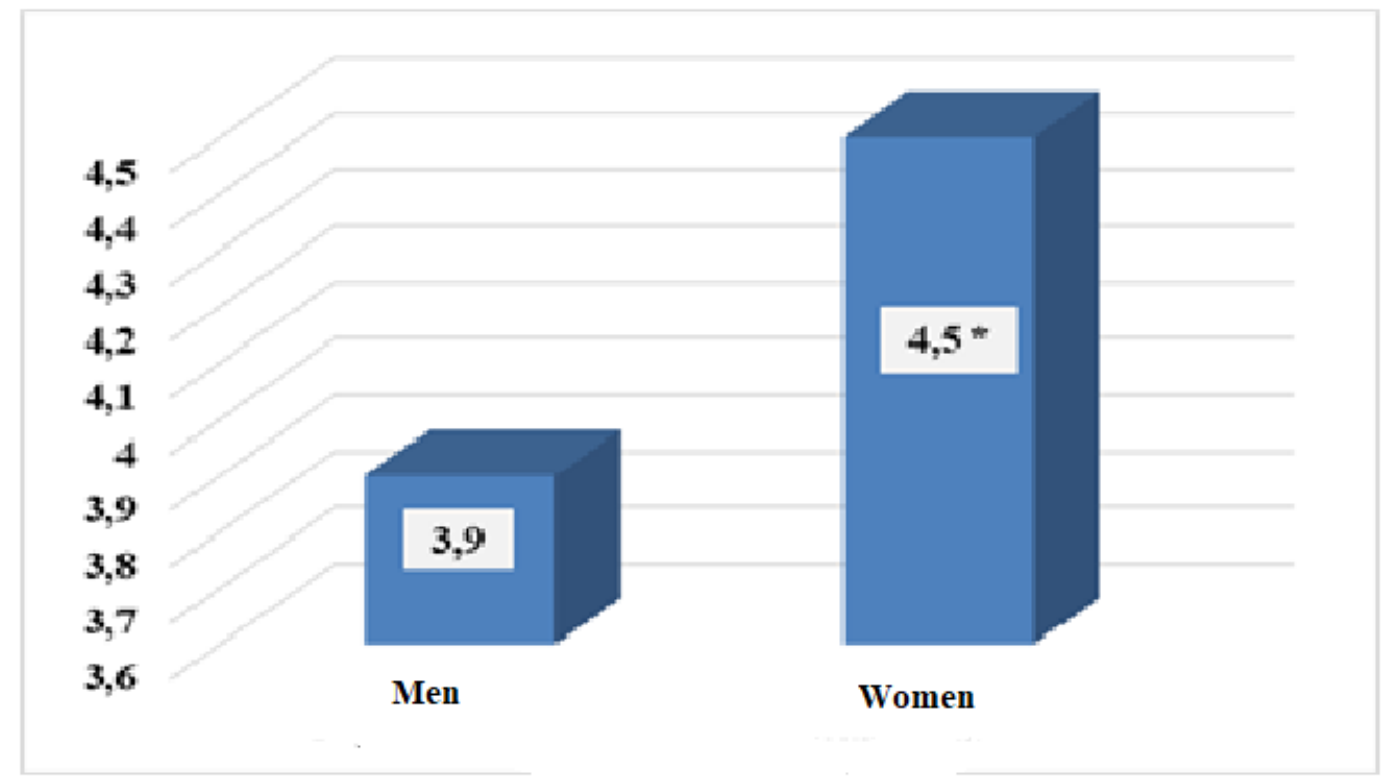

Figure 2 intensity of Asthenia on a five-point scale in points. $(*$ - reliability of differences, $p$ $<0.005)$.

Based on the literature data at the moment of knowledge about the pathogenesis of COVID19, it can be assumed that damage to the nervous system in this disease can cause not only direct contact with the virus, but also immune inflammation, hypoxia and hypoxemia against the background of acute respiratory distress syndrome, as well as an increased tendency to thrombus formation and at the same time the risk of hemorrhage against the background of disseminated intravascular coagulation syndrome $[1,3]$.

The structure of clinical manifestations in the acute period of the disease in the examined patients is shown in Table 3. As can be seen from this table, in general, patients more often had mild ARVI and pneumonia without acute respiratory failure (ARF). Mild ARVI and pneumonia without acute respiratory failure (ARF) were more common in men than in female patients. Women were more likely to have more severe manifestations of the disease - ARDS (pneumonia with ARF), sepsis, septic (infectious toxic) shock, disseminated intravascular coagulation syndrome, thrombosis and thromboembolism (Table 3 ).

Table 3

Structure of clinical manifestations COVID-19 
Published: May 30, 2021 | Pages: 157-163

\begin{tabular}{|l|c|c|c|c|}
\hline $\begin{array}{l}\text { Clinical variants and } \\
\text { manifestations of COVID-19 }\end{array}$ & \multicolumn{2}{|c|}{ Men, $\mathrm{n}=162$} & \multicolumn{2}{c|}{ Women, $\mathrm{n}=118$} \\
\cline { 2 - 5 } & $\mathrm{n}$ & $\%$ & $\mathrm{n}$ & $\%$ \\
\hline $\begin{array}{l}\text { 1. VRI (Viral Respiratory } \\
\text { Infections }\end{array}$ & 72 & $44,4 \%$ & 45 & $38,1 \%$ \\
\hline $\begin{array}{l}\text { 2.Pneumonia without } \\
\text { respiratory failure }\end{array}$ & 41 & $25,3 \%$ & 27 & $22,9 \%$ \\
\hline $\begin{array}{l}\text { 3. ARDS pneumonia from } \\
\text { CHN }\end{array}$ & 21 & $13,0 \%$ & 21 & $17,8 \%$ \\
\hline $\begin{array}{l}4 . \text { DIC syndrome } \\
\text { 5. Thrombosis and } \\
\text { thromboembolism }\end{array}$ & 12 & $7,4 \%$ & 11 & $9,3 \%$ \\
\hline
\end{tabular}

Note: ARf-acute respiratory failure.

ARDS-acute respiratory distress syndrome

In 62 patients with diagnosed pneumonia, the clinical picture was characterized by shortness of breath, varying degrees of severity, dry, exhausting cough, and weakness. The main clinical manifestations of the disease are presented in table 4.

In almost all of the 62 patients with lung involvement, the main complaint was dyspnea at rest and during exertion, and cough. At the same time, only $17.6 \%$ of people had a cough with sputum production.

Table 4

The main clinical manifestations of lung disease

\begin{tabular}{|l|c|c|c|}
\hline Symptoms & Men, $\mathrm{n}=38$ & Women, $\mathrm{n}=\mathbf{2 4}$ & $\mathrm{r}$ \\
\hline $\begin{array}{l}\text { Shortness of } \\
\text { breath, points }\end{array}$ & $2,5 \pm 0,3$ & $\mathbf{3 , 1 \pm 0 , 3}$ & $\mathbf{0 , 0 0 5}$ \\
\hline Cough, points & $\mathbf{2 , 6 \pm 0 , 9}$ & $3,1 \pm 0,7$ & $\mathbf{0 , 0 0 1}$ \\
\hline Stupum, points & $\mathbf{0 , 7 \pm 0 , 5}$ & $\mathbf{0 , 9} \pm 0,2$ & $\mathbf{0 , 0 1}$ \\
\hline
\end{tabular}


Published: May 30, 2021 | Pages: 157-163

Table 4 shows that the level of dyspnea in females was higher than in men $(3.1 \pm 0.3$ points versus $2.5 \pm 0.3$ points, respectively), this indicates that women, due to their physiological parameters had less VC. The same situation was observed in terms of points as cough.

The SpO2 level in group 1 was $95.2 \pm 2.2 \%$, which was higher than the $\mathrm{SpO} 2$ level in groups 2 and $3.95 .7 \pm 1.0 \%$, after 6 months $95.3 \pm 1.1 \%$ Saturation level indicators are shown in Figure 3 .

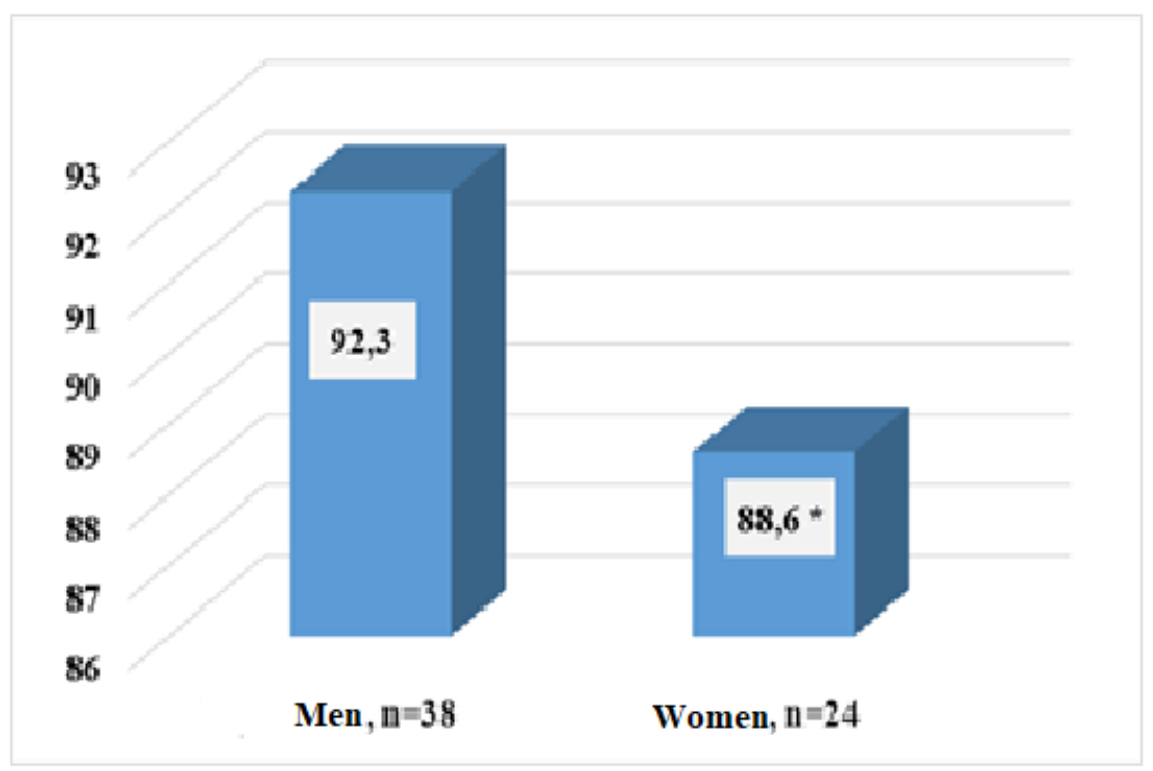

Figure 3.3 Saturation level in patients with lung disease

Depending on gender (* - reliability of differences, $p<0.005)$

On auscultation at the beginning of the study, hard breathing was heard in $18.3 \%$ of people, weakened breathing in $45.0 \%$ of people, dry wheezing was heard in $38.3 \%$ of people. Among male patients with dry wheezing there were $87.0 \%$, among women - $83.9 \%$.

\section{CONCLUSION}

Thus, in the clinic, gender differences were revealed in the examined patients. Thus, in female patients, the intensity of headache was significantly greater than in men, 8.1 points against 6.2 points on the VAS, respectively. Among female patients, asthenia was more pronounced compared to male patients 4.5 points and 3.9 points, respectively. In men, mild ARVI and pneumonia without acute respiratory failure (ARF) were more common than in female patients. Women were more likely to have more severe manifestations of the disease - ARDS (pneumonia 
Published: May 30, 2021 | Pages: 157-163

with ARF), sepsis, septic (infectious toxic) shock, disseminated intravascular coagulation syndrome, thrombosis and thromboembolism.

\section{REFERENCES}

1. Guo $\mathrm{T}$, Fan $\mathrm{Y}$, Chen $\mathrm{M}$, et al. Cardiovascular implications of fatal outcomes of patients with coronavirus disease 2019 (COVID-19). JAMA Cardiol. 2020;3201017. doi:10.1001/jamacardio.2020.1017ArticlePubMedGoogleScholar.

2. Helms J, Kremer S, Merdji H, et al. Neurologic features in severe SARS-CoV-2 infection. N Engl J Med. 2020;382(23):2268-2270. doi:10.1056/NEJMc2008597PubMedGoogle ScholarCrossref.

3. Mao L, Jin H, Wang M, et al. Neurologic manifestations of hospitalized patients with coronavirus disease 2019 in Wuhan, China. JAMA Neurol. 2020; 77: 683-690. doi:10.1001/jamaneurol.2020.1127 ArticlePubMedGoogleScholarCrossref 


\section{MATHEMATICAL REPRODUCTION OF ENERGETIC, YTTERBIUM-DOPED AMPLIFIER TUNABILITY}

\section{Francisco A.S.}

\section{Department Of Applied Science Federal University Of Rio De Janeiro Brazil}

\section{ABSTRACT}

The investigation of frequency tunability for the addition media Yb:CaF2 and Yb:YAG in a regenerative speaker design, was performed by utilizing a reenactment code beforehand benchmarked with genuine information. The outcomes show that the two materials have potential for intensifying heartbeats up to the milijoule level for frequencies around 1048-1049 $\mathrm{nm}$. Considering this, we propose and assess their presentation as gain media in the pre-speaker of a half breed chain working at $1053 \mathrm{~nm}$.

KEYWORDS: laser enhancers; reenactment; ytterbium lasers; diode-siphoned lasers;neodymium lasers.

\section{INTRODUCTION}

As of late, the supported advancement of high force diode lasers and their application as siphon gadgets in high pinnacle and normal force lasers have added to a developing exploration in various ytterbium-doped materials. Truth be told, the blend of these addition media and diode siphoning has end up being a very important choice for improvement of committed frameworks for siphoning energetic, high redundancy rate, ultrashort span optical parametric intensifiers and it is additionally a promising decision for the advancement of $\mathrm{Yb}$-based peeped beat enhancement (CPA) frameworks all alone, pointed toward coming to multi-Joule beats in the sub-picosecond system . The interest in Yb-doped media is supported by their novel spectroscopic properties bringing a larger number of benefits for diode siphoning than other customary increase media . They show a broadband assimilation cross-segment and high fluorescence lifetime at milisecond 
Published: May 30, 2021 | Pages: 164-167

time scales, low quantum deformity and a basic electronic construction that maintains a strategic distance from some parasitic impacts. Every one of these properties permit them to be siphoned productively at extremely high reiteration rates by low-splendor semiconductor lasers with emanation tops in range 920 to $980 \mathrm{~nm}$. Also, these media display an enormous addition transfer speed in the ghostly reach somewhere in the range of 1020 and $1070 \mathrm{~nm}$ equipped for supporting ultrashort beats enduring many femtoseconds, as was as of late showed by utilizing Yb3+:CaGdAlO4 (Yb:CALGO) to create $40 \mathrm{fs}$ beats.A huge number of Yb-doped hosts have been examined, described by slight contrasts in their spectroscopic boundaries relying upon the receiving family. This extraordinary assortment prompts an extensive affectability to the laser boundaries, requiring a cautious and solid demonstrating to assess the presentation of a given framework as far as e.g., frequency tunability and data transfer capacity development throughout regenerative or multipass enhancement. Specifically, in a regenerative intensifier the displaying is fundamentally more valuable since the net addition of the enhancement stage is normally 104 to 106and the generally low single-pass-acquire brings about high number of full circle trips . Therefore, we have recently fostered a reenactment code that was benchmarked with genuine trial information, to test and assess the laser exhibitions of various Yb-doped addition media .

\section{THE MAIN FINDINGS AND RESULTS}

We currently consider the development of an info beat inside a regenerative amplifieri.e., a cultivated hole, for various siphon powers. The info is picked to be a Gaussian heartbeat focused at $1053 \mathrm{~nm}$ with a FWHM data transmission of $12 \mathrm{~nm}$, well inside the addition transfer speed of both media. Albeit the underlying ghostly reaction of the framework is indistinguishable, one can expect that the development will be currently be dictated by these essentially extraordinary beginning conditions. Any remaining boundaries are equivalent to in the past area . Once more, the yield boundaries are taken at the greatest heartbeat energy. 
Published: May 30, 2021 | Pages: 164-167

This work has shown that it is possible to consider $\mathrm{mJ}$-level regenerative enhancement situated in $\mathrm{Yb}: \mathrm{CaF} 2$ and $\mathrm{Yb}: \mathrm{YAG}$ that can be tuned between two phantom pinnacles (1034-1048 $\mathrm{nm}$ in the principal case and 1032-1049 $\mathrm{nm}$ in the second) by changing just the siphon force of the framework. The recreations additionally show that accomplishing enhancement at $1049 \mathrm{~nm}$ with Yb:YAG is more diligently than for $\mathrm{Yb}: \mathrm{CaF} 2$ at $1048 \mathrm{~nm}$ because of the more prohibitive arrangement of boundaries accessible, in particular the need to utilize a low siphon power close to the increase limit, and low cavity misfortunes. This anyway still outcomes in a high number of passes, frequently more than 1000. The ideal tunability properties of Yb:CaF2 and Yb:YAG for frequencies around $1050 \mathrm{~nm}$ make them common contender for pre-speaker phases of frameworks situated in Nd:glass power intensifiers. We have investigated this chance by reproducing two cross breed intensification chains for both addition media, cultivated with a 12 $\mathrm{nm}$ signal focused at $1053 \mathrm{~nm}$. The two speakers permit acquiring yield beat energies over the $\mathrm{mJ}$ range, with a transfer speed of $2-3 \mathrm{~nm}$. While this is excessively thin for creating ultrashort beats, it is satisfactory in energy-arranged, sub-picosecond glass lasers. At last the last intensification stage supports this energy by two significant degrees without fundamentally narrowing the range. Taking everything into account, ytterbium-based regenerative intensification may demonstrate a reasonable mechanical choice for enormous scope, multi-shaft, high energy $\mathrm{Nd}$ :glass chains where productivity is a significant prerequisite.

\section{REFERENCES}

1. Zeal, A.H High energy picosecond Yb:YAG CPA framework at $10 \mathrm{~Hz}$ redundancy rate for siphoning optical parametric enhancers. Select. Express2012, 19, 5357-5364.

2. Kohler, B.; Yakovlev, V.V. Polaris: An All Diode-Pumped Ultrahigh Peak Power Laser for High Repetition Rates. In Laser and Nuclei, Lecture Notes in Physics; Springer: Berlin, Germany, 2007; Volume 694, pp. 47-67.

3. Krause, J.L.; Messina, M.; Wilson, K.R.;. New laser precious stones for the age of ultrashort beats. C.R.Physique2008, 8, 153-165.

4. Gu, X.; Xu, L.; Kimmel, M.; Zees, E.; O’Shea, P.; Shreenath,; Guandalini, A. 40-fs Yb3+:CaGdAlO4 laser siphoned by a solitary mode 350-mW laser diode. Pick. Express2013, 20, 10077-10081. 
Published: May 30, 2021 | Pages: 164-167

5. Cao, Q.; Gu, X.; Zeek, E.; Kimmel, M.. Mathematical and exploratory investigation of gain narrowing in ytterbium-based regenerative speakers. IEEE J. Quant. Electron. 2006, 41, 415-424.

6. Zhang, J.-Y.; Lee, C.-K.; Huang, J.Y. Assessment of cross breed ytterbium-neodymium laser intensification at $1054 \mathrm{~nm}$. Appl. Phys. B2011, 101, 103-109. 


\title{
PSYCHOLOGICAL FACTORS IN THE ADAPTATION OF ADOLESCENTS TO SPORTS
}

\author{
Fotima Ergashevna G'oziyeva
}

Phd at the National University Uzbekistan named after M. Ulugbek Uzbekistan

\author{
Matluba Berdali qizi Eshmuradova
}

2 nd year master's degree in psychology at the National University Uzbekistan named after M. Ulugbek Uzbekistan

ABSTRACT: In addition to being physically fit, playing sports helps to improve the morale of young people and increase their productivity. People who are mentally active, in particular, need to alternate their activities with exercise and movement. It is also useful from a psychological point of view. In order to shed light on the specifics of adolescent adaptation to sports sections, it is necessary to study in more depth the psychological characteristics of adolescent athletes. The adaptation of adolescent athletes to sports sections, the endurance of physical exercise, and the psychological strength to cope with them with perseverance and perseverance, positively affect the adolescent adaptation process. The role of the will in the process of adaptation is very important here. Willpower is manifested only in overcoming difficulties in achieving goals, physical and mental strength, and actions that require more or less various obstacles. I have tried to shed light on this in this article.

KEY WORDS- Adolescent, sports section, will, strength, endurance, adaptation, active and passive adaptation, physical fitness, temperament, character, motivation, discipline, confidence, initiative, independence, courage.

\section{INTRODUCTION}

Sport is the face of every country and nation. In the field of sports, special work is being done to bring up the children of the native land, which can protect the honor of our country. It 
Published: May 30, 2021 | Pages: 168-173

should be the duty of everyone to involve young people in sports, to instill in them a positive attitude towards sports.

Indeed, a lot of work is being done in our country to increase the popularity of physical culture and sports, to revive the national games, to form a healthy lifestyle, to train talented athletes in modern sports and to improve their skills. The policy pursued by the President of our country Shavkat Mirziyoyev is invaluable behind the positive work carried out in the field of sports.

\section{THE MAIN FINDINGS AND RESULTS}

It should be noted that our country has developed the following unique three-stage system, recognized by the world in the field of sports:

1. Annual "Sprouts of Hope" for schoolchildren;

2. "Harmoniously developed generation" for college students;

3. "At the University" for university students.

From the above, it is clear that a lot is being done in our country in the field of sports. As a result of this work, our athletes are leading in international competitions and raising their position in the world.

Athletes who are the subject of physical activity have their own individual and age characteristics, the dynamics of which can be determined and assessed by certain sociopsychological factors. Adolescents' adaptation to sports is likely to depend on their individual characteristics, emotional state, and behavior.

As for the concept of adaptation, it is the process of adaptation of the organism to the changing conditions of the environment. Adaptation maintains homeostasis stability in environmental conditions, ensuring maximum working life and production. However, not all people are able to fully and uniformly adapt to the same environmental conditions, depending on a person's gender, age, type of nervous system, level of health, physical fitness.

\section{RESULTS AND DISCUSSIONS}

Adaptation of adolescent athletes to sports sections is divided into two depending on their temperament and behavior: rapid (imperfect) and long-term (improved). 
Published: May 30, 2021 | Pages: 168-173

The rapid adaptive response occurs as soon as the effect begins and takes place through a pre-formed physiological mechanism. For example, protection against pain, increased heat production and reduction of heat loss in the body under the influence of strong cold, increased heat loss in response to high ambient temperature, increased circulatory and respiratory system function, functional systems adapts to the influence of factors that occur in the body as a result of such changes, that is, prevents the disruption of the life process.

Long-term adaptation is the gradual formation of the organism over a long period of time or with repeated exposure to environmental factors, ie this type of adaptation does not have preformed ready-made mechanisms. The study of human adaptation allows us to identify effective measures for adaptation to living conditions. There are active and passive types of adaptation.

In active adaptation - the body actively adapts to a set of environmental changes, changes in atmospheric pressure, the effects of high temperatures and sunlight, and so on. In passive adaptation, the body adapts to the disturbances of the internal environment caused by external factors. For example, passive adaptation is observed in conditions of lack of movement, hypokinesia, weightlessness and so on. This adaptation of the organism to the harmful effects of dissimilar factors is called passive adaptation.

Adaptation of adolescent athletes to sports sections, physical endurance, and the psychological strength to cope with them with perseverance and perseverance positively influences the adolescent adaptation process. Exercise is a natural part of adolescence. The gravitational pull of the earth, created by nature, has always affected mankind. Muscle function is an important factor in human adaptation to the environment. It is through the activity of temperature that the interaction between the organism and the environment takes place, and it adapts to the living environment. Just because physical activity is an integral part of life does not mean that everyone can do strenuous muscle work for long periods of time. This ability to work is achieved as a result of long-term regular exercise, adaptation. This process is mainly observed in people who are involved in intense muscle activity, ie athletes. Adolescent athletes' adaptation to sports differs from that of a person in the field of multidisciplinary adaptation, and it places special demands on the adolescent's body.

The first stage is associated with increased activity in the functional system that ensures the performance of a given exercise.

The second stage is the stabilization of the functional system. 
Published: May 30, 2021 | Pages: 168-173

The third stage is characterized by a violation of the balance between the demand for training and its satisfaction. This is due to the fatigue of the centers that control the activities of the internal organs and other organs of the movement.

A number of studies have found that, in addition to the physical, technical and tactical aspects of adolescent athletes 'participation in competitions, the need for their special psychological training is important. This training should be aimed at developing the willpower of the athlete, self-confidence, acquaintance with the nature of the upcoming competition, its scale, the characteristics of competitors.

It is very important to have high tactical skills in wrestling, boxing, fencing and other similar sports, and to adapt to this sport, that is, to quickly understand the problems in the situation and think about how to solve them quickly. Exercise and long-term exercise develop specialized perceptions. In addition, the willpower of the individual plays an important role in the adaptation of adolescents to sports. Strengthening the will of the adolescent athlete is part of psychological training.

So the will is the active side of the mind and the spiritual feeling. The will is a regulatory function of the brain. Willpower is a character trait that means consciously exerting a goal by setting a goal in advance and pre-determining the means to achieve that goal. Willpower is manifested only in overcoming difficulties in achieving goals, physical and mental strength, and actions that require more or less various obstacles. Nowadays, willpower factors are of great importance in the struggle of teenage athletes to win, as highly qualified athletes have a high level of physical, technical and tactical training.

The following can be included in the content of voluntary training of a teenager in adaptation to sports sections:

- goal-orientation;

- discipline;

- confidence;

- initiative;

- independence;

- courage;

- evidence;

- persistence. 
Published: May 30, 2021 | Pages: 168-173

Voluntary effort in the adaptation of adolescents to sports is associated with:

- voluntary exertion to relieve muscle tension;

- voluntary exertion during periods of increased attention;

- willpower related to overcoming fatigue and tiredness;

- voluntary coercion associated with obedience to the agenda;

- Voluntary coercion to overcome fear, etc.

All of the above should be well-developed in adolescence, otherwise the process of adaptation to the sport may be difficult or not at all.

In sports, as in any other field, the will of the adolescent sports sections greatly contributes to the process of exercise, as well as to overcoming all the difficulties of sports activities and adapting to these activities.

\section{CONCLUSION}

Based on the above, the following conclusions can be drawn. In the adaptation of adolescent athletes to sports sections, first of all, the psychological and physiological health of the adolescent is the basis of adaptation to the sports club.

Nowadays, willpower factors are of great importance in the struggle of adolescent athletes to win, as a number of studies (A. A. Lalayan, P. A. Rudik) have found that adolescent athletes are more likely to compete in physical, technical and tactical aspects. in addition, the need for their special psychological training is important. This training should be aimed at developing the willpower of the athlete, self-confidence, acquaintance with the nature of the upcoming competition, its scale, the characteristics of competitors. This means that today we need to strengthen the will of the athlete and provide him with physiological and psychological support before adapting him to the sports sections. Because sport is one of the best ways to raise the country's flag even higher.

\section{REFERENCES}

1. Gogunov E. N, Martinov B. I. "Psychology of physical education and sport”. - M: Academy. 2002-year.

2. Grigoryants I. A. "On the prospects for the development of sports psychology" - www. dedeve. narod. rb. 2005-year. 
Published: May 30, 2021 | Pages: 168-173

3. Grigoryants I. A. "The role of a coach in a sports team" - www.dedeve. narod. rb. 2005year.

4. Vygotsky L. S. "Development of higher mental functions" - M. 2003-year.

5. Gamezo M. V, Domashenko I. A. "Atlas of Psychology" - M. 2002-year.

6. Gippenreiter Yu. B. "Introduction to General Psychology" - M. 2002-year.

7. Matveev L.P. "General theory of sport" Textbook for the final level of higher physical education - M. FiS. 1997-year

8. Platonov V. M, Bulatova M. M. "Physical fitness of an athlete" - Kiev: 1995-year

9. Mamatov M. M. Text from the course "Sports Psychology" Tashkent, 1999-year.

10. E. G. Goziyev "General Psychology" Tashkent - "University" - 2002-year

11. Wikipedia.com

12. Broadbandsearch.net

13. .psihol.ru

14. psiholog.uz 